$$
\text { DOELET } 128393-\text { T2 }
$$

\title{
GEOTHERMAL ASSESSMENT OF A PORTION OF THE ESCALANTE VALLEY, UTAH
}

\author{
By Robert H. Klauk and Chad Gourley
}

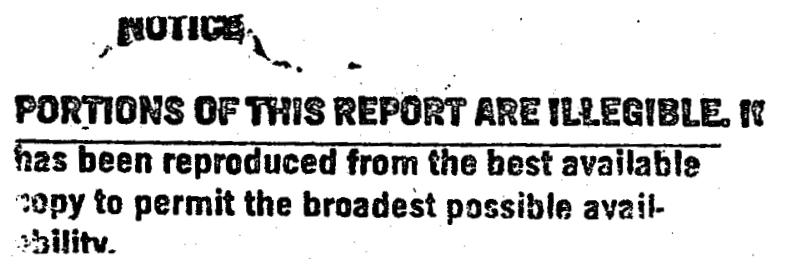

Prepared for

U.S. Department of Energy Idaho Operations Office Special Research Contract DE-AS07-77ET28393

UTAH GEOLOGICAL AND MINERAL SURVEY a division of Utah Department of Natural Resources

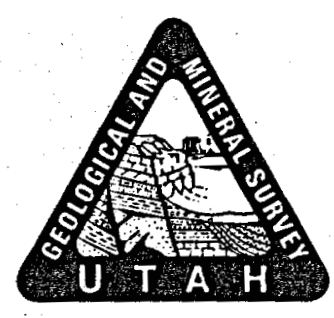




\section{DISCLAIMER}

This report was prepared as an account of work sponsored by an agency of the United States Government. Neither the United States Government nor any agency Thereof, nor any of their employees, makes any warranty, express or implied, or assumes any legal liability or responsibility for the accuracy, completeness, or usefulness of any information, apparatus, product, or process disclosed, or represents that its use would not infringe privately owned rights. Reference herein to any specific commercial product, process, or service by trade name, trademark, manufacturer, or otherwise does not necessarily constitute or imply its endorsement, recommendation, or favoring by the United States Government or any agency thereof. The views and opinions of authors expressed herein do not necessarily state or reflect those of the United States Government or any agency thereof. 


\section{DISCLAIMER}

Portions of this document may be illegible in electronic image products. Images are produced from the best available original document. 


\title{
STATE OF UTAH \\ Scott M. Matheson, Governor
}

\section{DEPARTMENT OF NATURAL RESOURCES \\ Temple A. Reynolds, Executive Director}

\section{UTAH GEOLOGICAL AND MINERAL SURVEY Genevieve Atwood, Director}

\begin{abstract}
BOARD
Kenneth R. Poulson, Chairman $\ldots \ldots \ldots \ldots \ldots \ldots \ldots \ldots \ldots \ldots \ldots \ldots \ldots \ldots \ldots \ldots$, Brush Wellman, Inc.

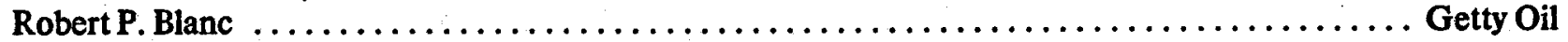

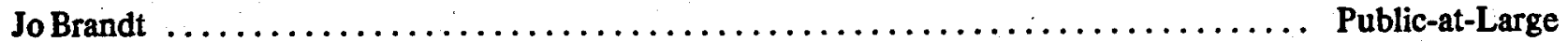

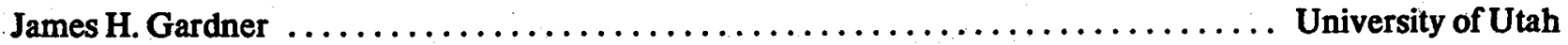
Robert L. Haffner $\ldots \ldots \ldots \ldots \ldots \ldots \ldots \ldots \ldots \ldots \ldots$ American Gilsonite/Chevron Resources E. Peter Matthies $\ldots \ldots, \ldots, \ldots, \ldots, \ldots, \ldots, \ldots, \ldots, \ldots, \ldots, \ldots$, Sharon Steel Corporation

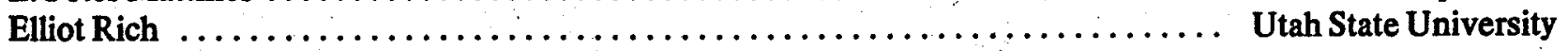
Ralph A. Miles, Director, Division of State Lands ..................... ex officio member UGMS EDITORIAL AND ILLUSTRATIONS STAFF

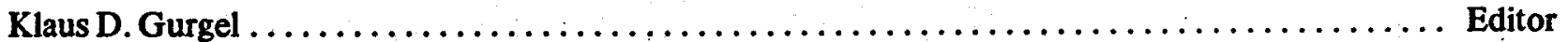

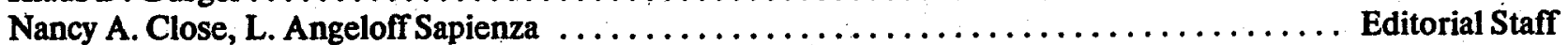
James W. Parker, Kent D. Brown, Jessie S. Roy $\ldots \ldots \ldots \ldots \ldots \ldots \ldots \ldots \ldots \ldots \ldots$ Cartographers
\end{abstract}

\section{DISCLAIMER}

This book was prepared as an account of work sponsored by an agency of the United States Government. Neither the United States Government nor any agency thereof, nor any of their employees, makes any warranty, express or implied, or assumes any legal liability or responsibility for the accuracy, completeness, or usefulness of any information, apparatus, product or process disclosed, or represents that its use would not infringe privately owned rights. References herein to any specific commercial product, process, or service by trade name, trademark, manufacturer, or otherwise, does not necessarily constitute or imply its endorsement, recommendation, or favoring by the United States Government or any agency thereof. The views and opinions of authors expressed herein do not necessarily state or reflect those of the United States Government or any agency thereof. 


\section{GEOTHERMAL ASSESSMENT OF A PORTION OF THE ESCALANTE VALLEY, UTAH}

Available from
National Technical Information Service
U.S. Department of Commerce
5285 Port Royal Road
Springfield, VA 22161
NTIS Price Codes: Printed Copy A04
Microfiche A01

\section{DISCLAIMER}

This report was prepared as an account of work sponsored by an agency of the United States Government. Neither the United States Government nor any agency thereof, nor any of their employees, makes any warranty, express or implied, or assumes any legal liability or responsibility for the accuracy, completeness, or usefulness of any information, apparatus, product, or process disclosed, or represents that its use would not infringe privately owned rights. Reference herein to any specific commercial product, process, or service by trade name, trademark, manufacturer, or otherwise does not necessarily constitute or imply its endorsement, recommendation, or favoring by the United States Government or any agency thereof. The views and opinions of authors expressed herein do not necessarily state or reflect those of the United States Government or any agency thereof.

$$
\begin{aligned}
& \text { Prepared for } \\
& \text { U.S. Department of Energy } \\
& \text { Idaho Operations Office } \\
& \text { Special Research Contract } \\
& \text { DE-ASQ7-77ET28393 }
\end{aligned}
$$




\section{CONTENTS}

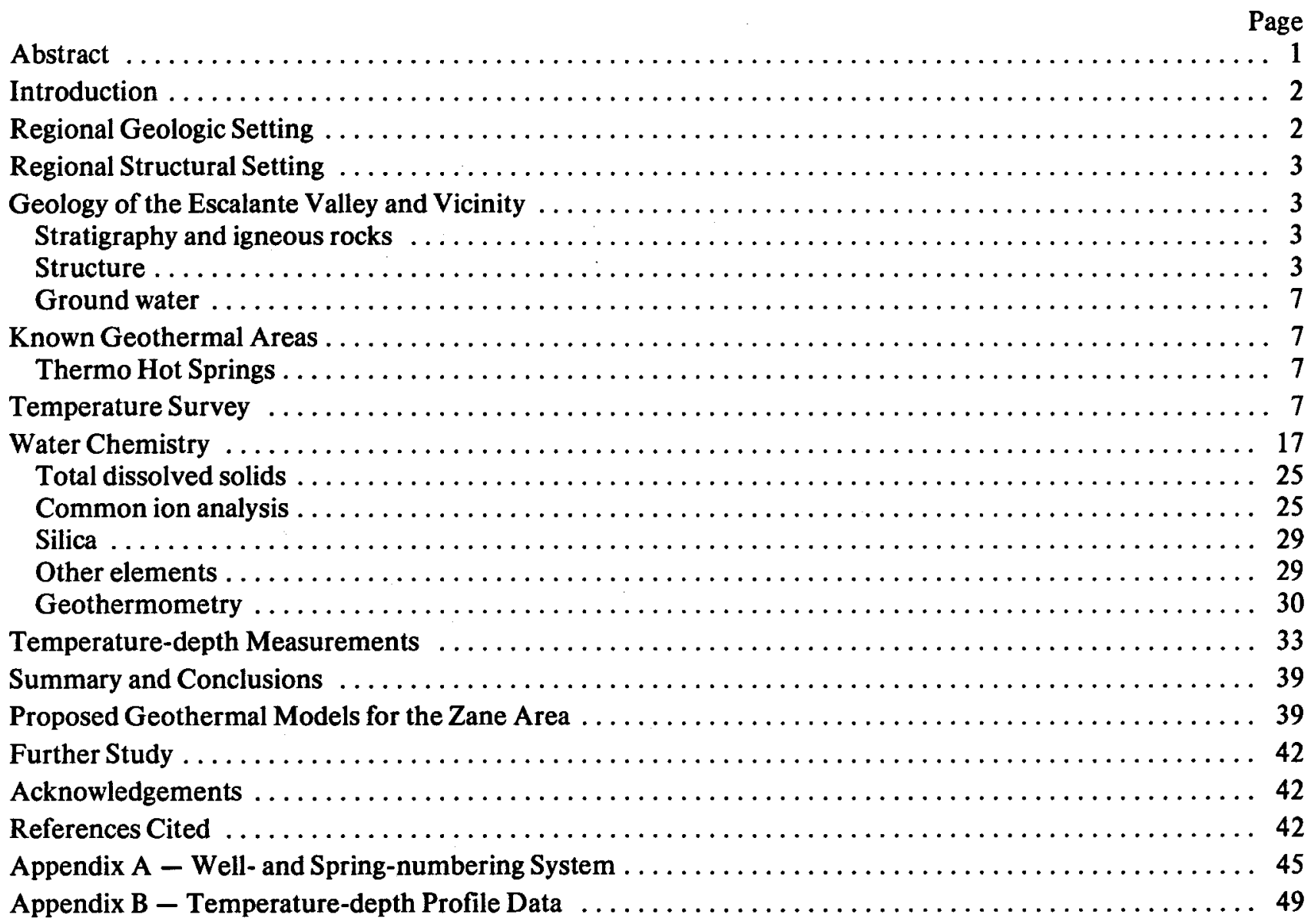

\section{ILLUSTRATIONS}

Page

Figure 1. Index map showing the locations of the Escalante Valley, Utah. ................. 2

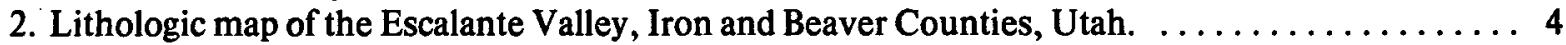

3. Major structural and physiographic features of the Escalante Desert and vicinity. . . . . . . . 6

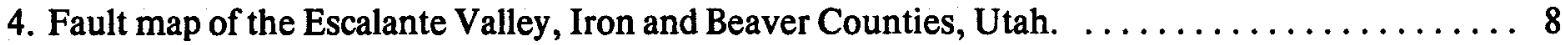

5. Complete Bouguer gravity map of the Escalante Valley, Iron and Beaver Counties, Utah. . . . . 10

6. Hydrologic units in the Escalante Valley, Iron and Beaver Counties, Utah. . . . . . . . . 12

7. Potentiometric survey contour map of Escalante Valley, Iron and Beaver Counties, Utah. . . . . 14

8. Ground-water temperature map of the Escalante Valley, Iron and Beaver Counties, Utah. . . . . 18

9. Well and spring chemistry sample locations, Escalante Valley, Iron and Beaver Counties, Utah. . 20

10. Total dissolved solids (TDS) measured in the Escalante Valley, Iron and

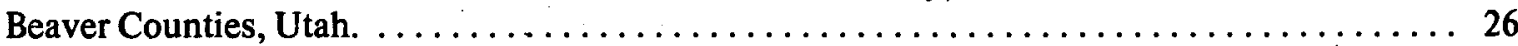

11. Piper diagram of common ions in samples collected from Area VII (Figure 9) in the Escalante Valley, Utah. . . . . . . . . . . . . . . . . . . 28

12. Piper diagram of common ions in samples collected from Area $V$ (Figure 9) in the Escalante Valley, Utah. . . . . . . . . . . . . . . . . . . . . 28

13. Piper diagram of common ions in samples collected from Area III (Figure 9) in the Escalante Valley, Utah. . . . . . . . . . . . . . . . . . 28

14. Piper diagram of common ions in samples collected from Area I (Figure 9) in the Escalante Valley, Utah. 
15. Piper diagram of common ions in samples collected from Area II (Figure 9) in the Escalante Valley, Utah.

16. Piper diagram of common ions in samples collected from Area IV (Figure 9) in the Escalante Valley, Utah.

17. Piper diagram of common ions in samples collected from Area VI (Figure 9) in the Escalante Valley, Utah. . . . . . . . . . . . . . . . . . 30

18. Piper diagram of common ions in samples collected from Thermo Hot Springs (Figure 9) in

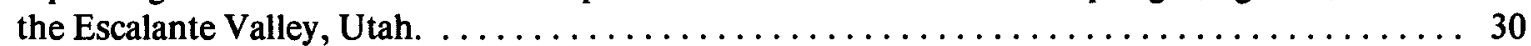

19. Piper diagram of common ions in all samples collected in the Escalante Valley, Utah. . . . . . 30

20. Plot of lithium ( $\mathrm{Li}$ ) versus boron (B) values for only those samples where both elements were present in detectable limits in the Escalante Valey, Utah.

21. Locations of selected "holes of opportunity" in the Escalante Valley, Iron and

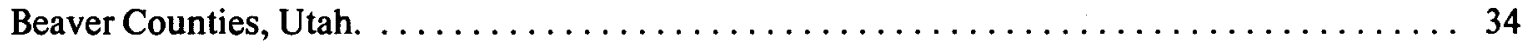

22. Temperature-depth profile of a "hole of opportunity" logged in Area A (Figure 21)

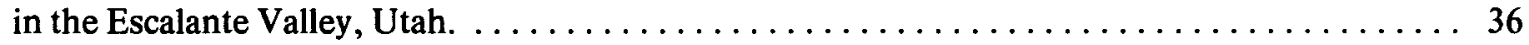

23. Temperature-depth profile of a "hole of opportunity" logged in Area A (Figure 21) in the Escalante Valley, Utah. . . . . . . . . . . . . . . . . . . . 36

24. Temperature-depth profiles of "holes of opportunity" logged in Area B (Figure 21) in the Escalante Valley, Utah. . . . . . . . . . . . . . . . . . 36

25. Temperature-depth profile of a "hole of opportunity" logged in Area B (Figure 21)

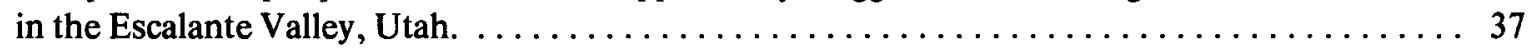

26. Temperature-depth profile of a "hole of opportunity" logged in Area C (Figure 21)

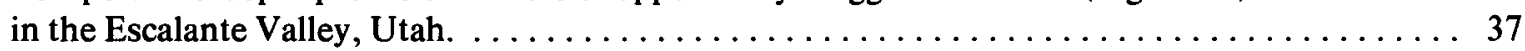

27. Temperature-depth profiles of "holes of opportunity" logged in Area C (Figure 21)

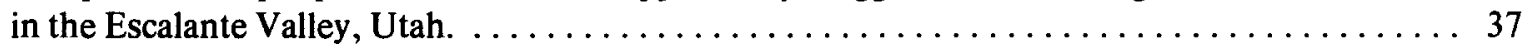

28. Temperature-depth profiles of "holes of opportunity" logged in Area D (Figure 21)

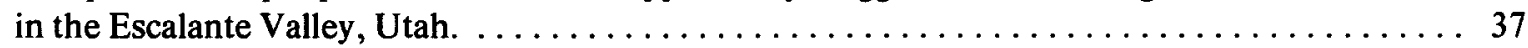

29. Temperature-depth profiles of "holes of opportunity" logged in Area D (Figure 21)

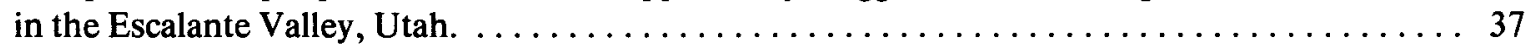

30. Model I proposed for the geothermal anomaly northwest of Zane, Iron County, Utah. . . . . . 40

31. Model II proposed for the geothermal anomaly northwest of Zane, Iron County, Utah. . . . . . 40

32. Model III proposed for the geothermal anomaly northwest of Zane, Iron County, Utah. . . . . . 41

\section{TABLES}

Table 1. Hydrologic units and their qualitative hydrologic properties (from Moyer, 1982)

2. Limits of quantitative determination (LQD) for solution analysis by the University of

Utah Research Institute/Earth Science Lab Inductively Coupled Plasma Quantometer. . . . . . . 17

3. Water analysis from wells and springs in the Escalante Valley, Utah. . . . . . . . . . . 22

4. Chemical geothermometers with magnesium correction where applicable and surface

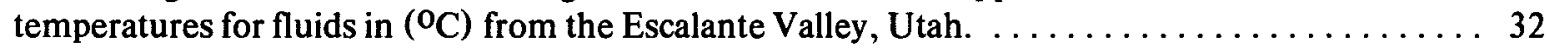

5. Geothermal gradient data for 22 "holes of opportunity" logged in the Escalante Valley, Utah. . . . 38 


\title{
GEOTHERMAL ASSESSMENT OF A PORTION OF THE ESCALANTE VALLEY, UTAH
}

\author{
By Robert H. Klauk ${ }^{l}$ and Chad Gourley ${ }^{2}$
}

\begin{abstract}
In February 1981, the Utah Geological and Mineral Survey (UGMS) contracted with the Department of Energy (DOE) to evaluate the geothermal potential of an area proposed for a possible Missile Experimen. tal (MX) operations base in the Escalante Valley region of Utah (DOE contract DE-AS07-77ET 28393). Exploration techniques employed included a temperature survey, chemical analysis of springs and wells, and temperature-depth measurements in "holes of opportunity." The highest water temperatures recorded in the area, with the exceptions of a $60^{\circ} \mathrm{C}\left(140^{\circ} \mathrm{F}\right)$ geothermal exploration hole and Thermo Hot Springs $\left(42\right.$ to $78^{\circ} \mathrm{C}$ or 108 to $172^{\circ} \mathrm{F}$ ), were 27 and $28^{\circ} \mathrm{C}\left(81\right.$ and $\left.82^{\circ} \mathrm{F}\right)$ at two wells located northwest of Zane, Utah.

Total dissolved solid values in tested waters ranged from 276 to $5360 \mathrm{mg} / \mathrm{l}$. Areas of relatively high total dissolved solids (greater than $1400 \mathrm{mg} / \mathrm{l}$ ) were located primarily in the Zane area. Trilinear plots of common ion analysis of water samples collected resulted in three designated types as well as two individual anomalous values. Type III waters consist of all samples from Thermo Hot Springs, Type II waters consist of samples collected northwest of Zane, and Type I waters consist of all but two of the remaining samples. Of all trace elements tested for, lithium ( $\mathrm{Li}$ ) and boron (B) were present above detectable limits in most samples. Lithium values ranged from undetectable to $1.07 \mathrm{mg} / \mathrm{l}$; values for samples in the Zane area ranged from 0.96 to $1.07 \mathrm{mg} / \mathrm{l}$ with the exception of EV-116 $(0.26 \mathrm{mg} / \mathrm{l})$. Zane area values also correlate with Thermo Hot Springs. Boron values of water samples ranged from undetectable to $1.2 \mathrm{mg} / 1$. Boron concentrations in water from three wells sampled northwest of Zane ranged from 0.9 to $1.2 \mathrm{mg} / 1$, which are similar to the $1.0 \mathrm{mg} / 1 \mathrm{~B}$ values measured at Thermo Hot Springs.

$\mathrm{Na}-\mathrm{K}-\mathrm{Ca}$ geothermometer temperatures computed for the three samples northwest of Zane ranged from
\end{abstract}

\footnotetext{
${ }^{1}$ Geologist, Energy Section, Utah Geological and Mineral Survey. ${ }^{2}$ Formerly with Utah Geological and Mineral Survey, Energy Section, presently with Utah State Division of Water Rights.
}

100 to $120^{\circ} \mathrm{C}$ ( 212 to $248^{\circ} \mathrm{F}$ ). All other Na-K-Ca temperatures computed for other water well samples were no greater than $74^{\circ} \mathrm{C}\left(165^{\circ} \mathrm{F}\right)$. Fournier (1977) suggests that if the $\mathrm{Na}-\mathrm{K}-\mathrm{Ca}$ thermometer indicates temperatures less than $100^{\circ} \mathrm{C}\left(212^{\circ} \mathrm{F}\right)$, the silica temperature of the water is a function of chalcedony solubility. For temperatures greater than $100^{\circ} \mathrm{C}$ $\left(212^{\circ} \mathrm{F}\right)$, silica content is a function of quartz solubility. Quartz (conductive) temperatures for the three wells sampled northwest of Zane ranged from 96 to $104^{\circ} \mathrm{C}$ ( 205 to $219^{\circ} \mathrm{F}$ ) and are comparable to the $\mathrm{Na}-\mathrm{K}-\mathrm{Ca}$ temperatures. Chalcedony temperatures ranged from 10 to $80^{\circ} \mathrm{C}\left(50\right.$ to $\left.176^{\circ} \mathrm{F}\right)$ for the remainder of the water well samples.

Temperature-depth measurements were completed in 22 "holes of opportunity" in the study area. Gradients calculated ranged from isothermal to $138^{\circ} \mathrm{C}$ $\left(280^{\circ} \mathrm{F}\right)$. The highest gradient was located $0.9 \mathrm{mi}(1.5$ $\mathrm{km})$ west of sample location EV-150, which had the highest recorded water well temperature $\left(28^{\circ} \mathrm{C}\right.$ or $\left.82^{\circ} \mathrm{F}\right)$.

Water temperatures, aqueous chemistry and temperature-depth data define a geothermal anomaly that may reflect a low-temperature geothermal resource. Further work is needed, however, to define the resource.

\section{CONVERSION FACTORS}

Water temperatures are reported in degrees centigrade $\left({ }^{\circ} \mathrm{C}\right)$ with degrees Farenheit $\left({ }^{\circ} \mathrm{F}\right)$ in parenthesis in the text. Water temperatures are reported only in $\left({ }^{\circ} \mathrm{C}\right)$ in Figures and Tables. Water temperature can be converted from $\left({ }^{\circ} \mathrm{C}\right)$ to $\left({ }^{\circ} \mathrm{F}\right)$ by the following equation: ${ }^{\circ} \mathrm{F}=1.8\left({ }^{\circ} \mathrm{C}\right)+32$.

Chemical concentrations are given in milligrams per liter $(\mathrm{mg} / \mathrm{l})$ which is a unit expressing the solute per unit volume (liter) of water.

Gradients are given in degrees centigrade per kilometer and can be converted to degrees Farenheit per 100 feet by the following conversion: $18^{\circ} \mathrm{C} / \mathrm{km} \approx$ $1^{\circ} \mathrm{F} / 100$ feet.

Meters can be changed to feet in the Figures and Tables by the following equation: $1 \mathrm{~m}=3.28$ feet. 


\section{INTRODUCTION}

The Escalante Valley is a typical Basin and Range valley encompassing an area of $800 \mathrm{mi}^{2}(2080 \mathrm{~km}$ ) in Iron County and parts of Beaver and Washington Counties in southwestern Utah (Figure 1). Cedar City, the major metropolitan center in this part of the state, is located approximately $25 \mathrm{mi}(40 \mathrm{~km})$ to the east. Principal communities within the valley include Newcastle, Beryl Junction, and Modena; Lund, Beryl and Zane are small communities located along the Union Pacific Railroad and are likewise found in the study area. Thermo Hot Springs is also located in the valley. This study was undertaken to determine the existence of any unknown geothermal anomalies in the region.

The UGMS has been conducting research to advance the utilization of low-temperature geothermal resources in the State of Utah on a cost share basis with the U.S. Department of Energy (DOE contract DE-AS07-77ET 28393). In February 1981, the UGMS contracted with the Department of Energy to evaluate the geothermal potential in the Escalante Valley region of Utah, an area proposed for a possible Missile Experimental (MX) operations base. The exploration techniques employed during the study included:

(1) Temperature survey of selected wells and springs;

(2) chemical analysis of fluids from selected wells and springs;

(3) temperature-depth measurements of selected holes of opportunity.

\section{REGIONAL GEOLOGIC SETTING}

The geology of southwestern Utah represents a long depositional history coupled with extensive igneous activity. During Late Precambrian time (oldest rocks exposed in area are Late Precambrian quartzites), the Cordilleran miogeosyncline was well developed (Stewart and Poole, 1974). Cambrian strata here are similar to that found in most areas of Utah; a basal sandstone (Prospect Mountain Quartzite) conformably overlain by a thin shale (Pioche Shale), which in turn is overlain by thick undifferentiated carbonates (Hintze, 1963a). Thick sequences of carbonates, with minor units of sandstone, siltstone, and shale, continued to be deposited throughout most of the remainder of the Paleozoic Era and include the Ordovician Pogonip Group, Eureka Quartzite, and Fish Haven Dolomite; the Silurian Laketown Dolomite; the Devonian Sevy Dolomite, Simonson Dolomite, Guilmette Formation, and Pilot Shale; the Mississippian Joana Lime-

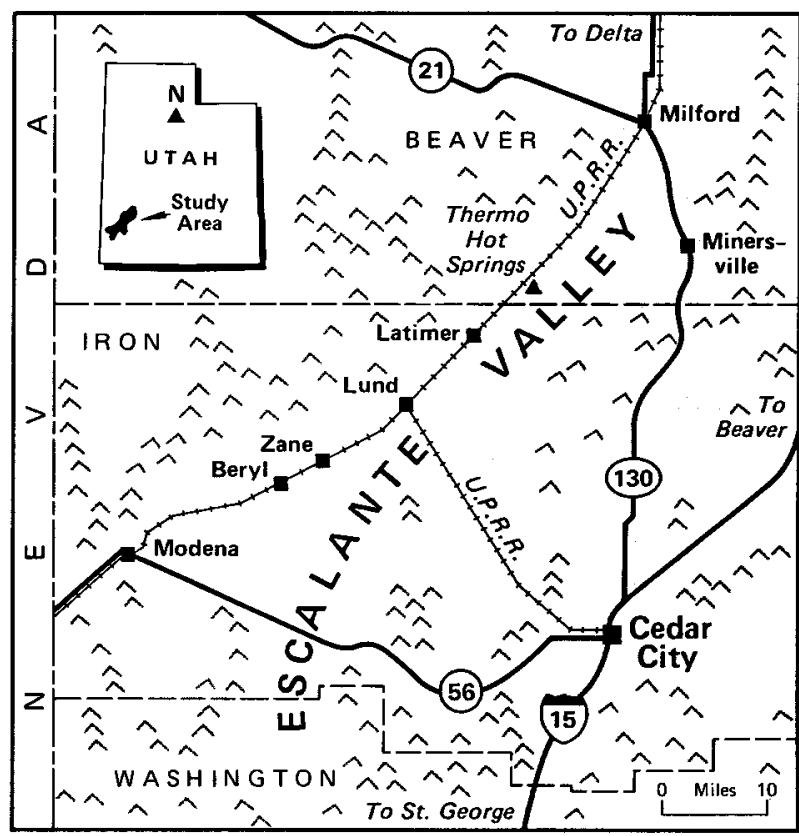

Figure 1. Location map of the Escalante Valley, Utah.

stone and Chainman Shale; the Pennsylvanian Illipah Formation and Ely Limestone; and the Permian Arcturus Formation, Supai-Coconino-Toroweap Formations, and Kaibab Limestone.

During the Early Triassic, thick sediments of the miogeosyncline were uplifted to become the Mesocordilleran Highlands. The growth of these highlands was accomplished in a number of orogenic episodes affecting different areas through several geologic periods (Stokes, 1963). Sediment eroded from these highlands was deposited in marginal basins to the east. During Triassic and Jurassic time, thick sequences of siltstone, sandstone, conglomeritic sandstone and eolian sands were deposited; units include the Triassic Moenkopi Formation, Chinle Formation, Jurassic Navajo Sandstone, and San Rafael Group (Crosby, 1973; and Hintze, 1973). In Cretaceous time, the lenticular beds of coarse sandstone and conglomerate of the Iron Springs Formation were deposited. The Laramide Orogeny continued into the Early Tertiary, and the Claron Formation was deposited (Rowley and others, 1979).

An extensive volcanic sequence was extruded in southwestern Utah during the Middle Tertiary. Volcanic activity, which commenced in Late Eocene time, was "one of the most violent and intensive periods of volcanism in North America" (Stokes and Heylum, 1963). This sequence consists of intermediate calc-alkaline stratavolcanoes and regionally distributed ash-flow tuffs (Rowley and others, 1979). These volcanic rocks were deposited conformably 
upon, and were sometimes interbedded with the Claron Formation (Mackin, 1947). Beginning 20 million years ago (Miocene time) the igneous activity shifted to alkalic basalt and alkalic rhyolite extrusives, a shift contemporaneous with the onset of Basin and Range faulting (Rowley and others, 1979). Fluvial and lacustrine deposits filled the developing basins concurrent with the volcanics.

\section{REGIONAL STRUCTURAL SETTING}

Southwestern Utah has a very diverse tectonic setting. A prominent structural feature in this area is the Wasatch tectonic hinge line (hereafter referred to as the Wasatch Line), which, for the most part, divides southern Utah into two distinct provinces: (1) the Basin and Range to the west and (2) the Colorado Plateau to the east. In southwestern Utah the Wasatch Line is thought to connect with the Las Vegas tectonic hinge line (hereafter referred to as the Las Vegas Line), which extends through southern Nevada forming a continuous fault system with the Garlock fault in southern California (Welsh, 1959). Associated with the Wasatch Line is a transition zone separating the relatively undeformed strata of the Colorado Plateau from extensively folded and thrustfaulted rocks of the Basin and Range. In the study area, Armstrong (1968) refers to the Sevier orogenic belt as the Wah Wah-Canyon Range sector. The thrust faults named in this sector consist of the Wah Wah, Frisco, Mineral Range, Pavant and Canyon Ranges (Armstrong, 1968). In southwestern Utah this belt varies from zero to tens of miles in width (Crosby, 1973). Kay (1951) indicates the Wasatch Line extends in a southerly direction from southwestern Utah, continuing through Arizona and into northern Mexico. This indicates that three important lines of disturbance converge in southwestern Utah, the northern branch being the main Wasatch Line, the southern branch being Kay's extension of the Wasatch Line, and the southwestern branch being the Las Vegas Line (Stokes, 1976). In addition, the Southern Great Basin volcanic or ignimbrite field clearly lies upon and parallels the Las Vegas Line (Stokes, 1976). In southwestern Utah, the northwest border of the Transcontinental arch, which extends northeasterly through the North American continent, also coincides with the Las Vegas Line.

\section{GEOLOGY OF ESCALANTE VALLEY AND VICINITY \\ Stratigraphy and Igneous Rocks}

The Escalante Valley is filled with unconsolidated to semi-consolidated alluvial, colluvial, lacustrine and aeolian deposits to a maximum thickness of approximately $1000 \mathrm{ft}(305 \mathrm{~m})$ (Mower, 1981). A gravity survey of the area conducted by Win Pe (1980) indicates unconsolidated sediments extend much deeper. Figure 2 illustrates the distribution of these sediments. The mountainous terrain surrounding the study area consists primarily of igneous deposits; Paleozoic and Mesozoic sediments are primarily limited to the areas northwest and southeast of the valley. To the northwest, Middle Cambrian to Early Pennsylvanian deposits are thrust over Early Triassic to Late Jurassic strata (Miller, 1966). To the southeast, Cretaceous rocks of the Iron Springs Formation and some limited exposures of the Tertiary Claron Formation are found.

Igneous rocks cropping out within the study area are principally volcanic, but outside the area, intrusive monzonite porphyry stocks are present to the south and southeast (Figure 2). The Escalante Desert lies between two regional, generally east trending, igneous belts: the Pioche-Marysvale belt to the north and the Delamar-Iron Springs belt to the south (Rowley and others, 1979) (Figure 3). The ages of these belts are thought to be 26 and 20 million years old, respectively. The composition of the igneous rocks in the study area is consistent with that previously mentioned for southwestern Utah; older calcalkaline volcanics and younger rhyolitic and basaltic extrusives. Minor basalt flows are present to the west and southwest.

\section{Structure}

The Escalante Valley has been influenced by four significant geologic events: (1) large scale thrustfaulting of the Sevier orogeny; (2) east-west trending igneous activity; (3) Basin and Range tectonism; and (4) periods of intensive volcanism with associated intrusive activity.

A number of thrusts have been included in the Wah Wah-Canyon Range sector, but only the Blue Mountain thrust (in the Wah Wah Mountains) has been mapped in the vicinity of the Escalante Valley. The Blue Mountain thrust plate consists of Cambrian carbonates overriding Jurassic sandstone, forming a structurally complex zone about $15 \mathrm{mi}(4.6 \mathrm{~km})$ wide to the west of the Wah Wah thrust fault (Miller, 1963). The Blue Mountain thrust plate sequence is imbricated and, in places, overturned. At its easternmost exposure, this thrust dips below the Escalante Valley alluvium and therefore its eastern limit is not known (Miller, 1963). Although the Blue Mountain thrust can only be dated as post-Upper Jurassic, on the basis of regional relationships, it is part of a belt 


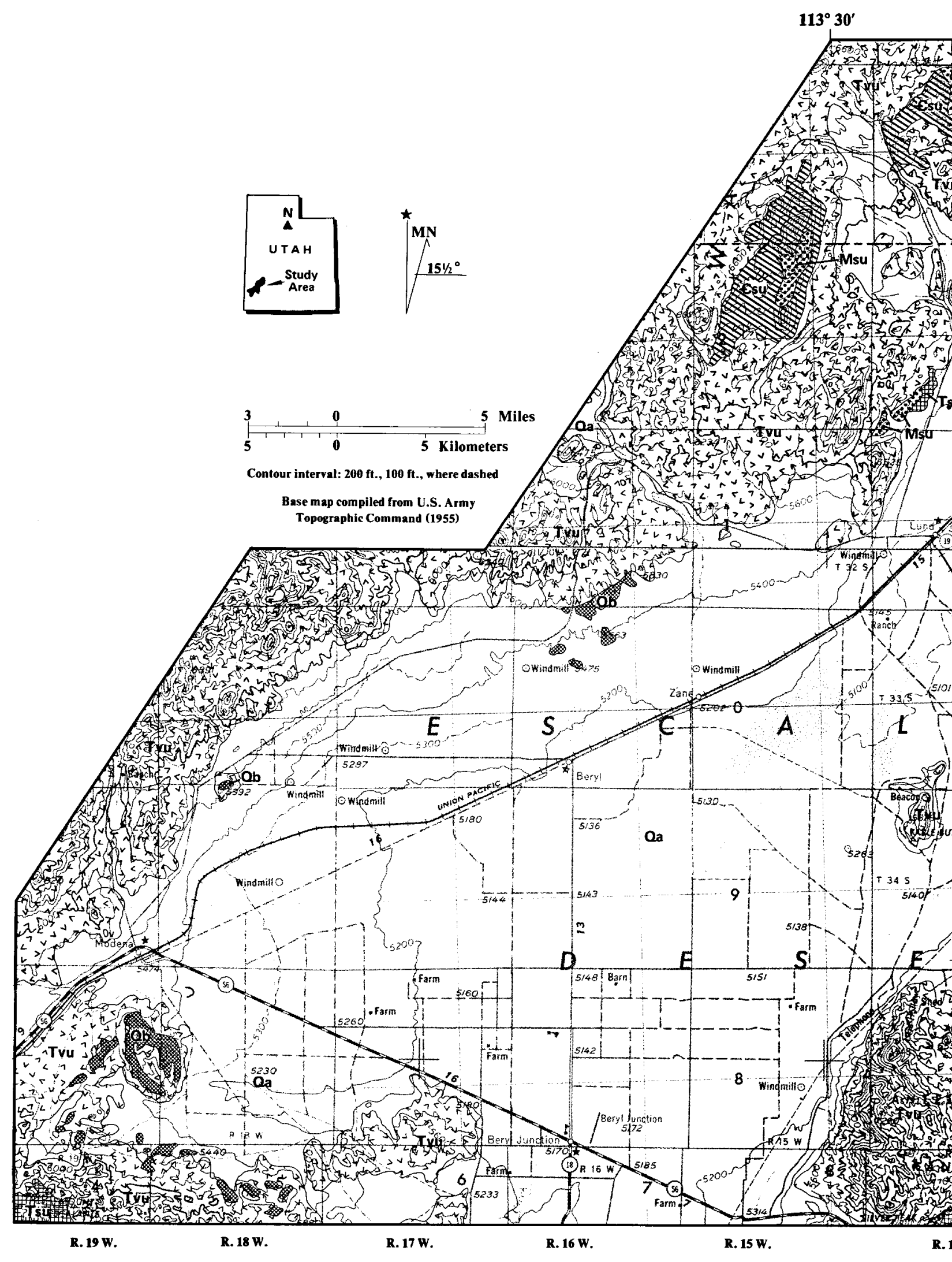




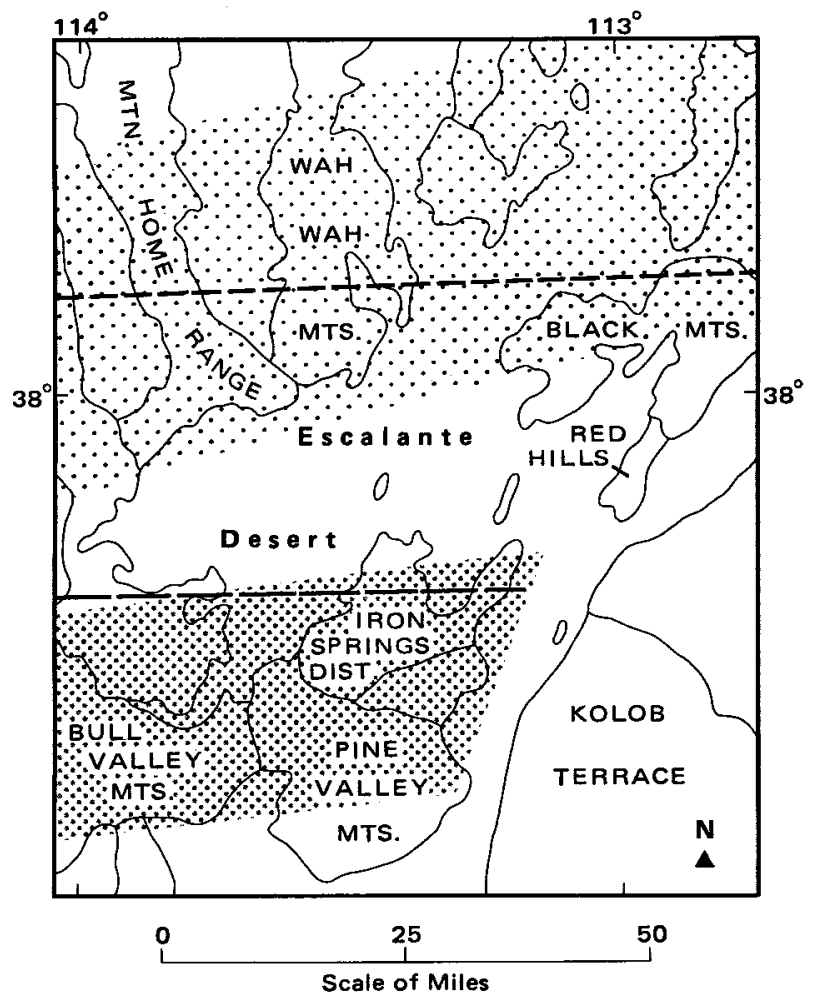

EXPLANATION

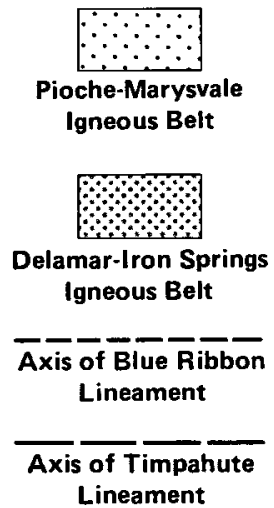

Figure 3. Major strucutral and physiographic features of the Escalante Desert and vicinity (modified after Rowley and others, 1979).

of Laramide age thrusts developed near the eastern border of the Great Basin (Miller, 1963).

The Pioche-Marysvale igneous belt and the Delamar-Iron Springs belt (mentioned previously as bordering the Escalante Desert to the north and south, respectively) are both thought to be structurally controlled (Rowley and others, 1979). Rowley and others (1979) also state that these belts contain most of the known volcanic centers, plutons, hot springs, igneous-related mineralized rocks and hydrothermally-altered rocks in southwestern Utah as well as virtually all the known east-striking faults.

Two east-west oriented lineaments have been identified as extending into or through the Escalante Valley (Figure 3). The first is known as the Blue Ribbon lineament (Rowley and others, 1978) and is a feature approximately $15 \mathrm{mi}(25 \mathrm{~km})$ wide and 222 mi $(360 \mathrm{~km})$ long that extends from the central Sevier Plateau westward into Nevada. This lineament is located along the southern extent of the PiocheMarysvale igneous belt; predominant movement along the east-striking faults appears to be dip-slip (Rowley and others, 1978). The second lineament, referred to as the Timpahute lineament, was defined by Ekren and others (1976) as extending from west of the Tempiute mining district in southeast Nevada to just east of the Utah-Nevada state line. Rowley and others (1979) have extended this lineament to the north side of the Delamar-Iron Springs igneous belt, as far east as Cedar City. Basin and Range tectonism is considered to have occurred more or less concurrently with the east-west trending igneous activity mentioned above. The orientation of the Basin and Range faults resulting from this tectonism is northnortheast (Rowley and others, 1979). In the Escalante Valley area, active faulting is considered to be younger than 10 m.y. ago; Anderson and Mehnert (1979) state that Pleistocene faults are abundant, and Anderson and Miller (1979) have located Quaternary faults in the Escalante Valley (Figure 4). Anderson and Bucknam (1979) report Holocene deformation resulting in at least $99 \mathrm{ft}(30 \mathrm{~m})$ of uplift in a $312 \mathrm{mi}^{2}$ $\left(800 \mathrm{~km}^{2}\right)$ area near Enterprise in the southern Escalante Valley, with faulting still active in the area.

During Oligocene and Miocene time great thicknesses of ignimbrites as well as lava flows, volcanic mudflows, and blanket deposits of airfall and waterlaid tuff were produced. Stokes and Heylum (1963), and Crosby (1973) suggest that parts of the Escalante Valley as well as other areas of southwest Utah are analagous to a collapsed caldera resulting from the removal of support within the earth's crust. According to Win Pe (1980) and Clement (1980) there is no strong geological and geophysical evidence to support this hypothesis.

Win Pe (1980) conducted a gravity survey of the Escalante Desert and vicinity. Results of the survey and the conclusions drawn follow. The dominant features in the valley are oriented northeast-southwest and are possibly controlled by the northeast trending features of Laramide Age. Northeast trending large gravity lows indicate three grabens in the vicinities of Newcastle, Lund, and Avon with characteristic Basin 
and Range structure (Figure 5). The depth to bedrock in these three grabens is estimated to be $1.9 \mathrm{mi}$ $(3 \mathrm{~km}), 1.1 \mathrm{mi}(1.8 \mathrm{~km})$, and $1.3 \mathrm{mi}(2 \mathrm{~km})$, respectively. Two intermediate gravity lows, indicating grabens, are in the vicinities of South Beryl and East Modena; these structures are thought to have been shaped principally by east-west trending pre-Basin and Range igneous activity (Figure 5). Depths to bedrock in these two grabens is estimated to be $1.4 \mathrm{mi}$ $(2.2 \mathrm{~km})$ and $0.8 \mathrm{mi}(1.2 \mathrm{~km})$ respectively. A gravity high over the Beryl area could be indicative of bedrock that has been complexly deformed by igneous intrusions at shallow depth (Figure 5). A northeast extension of this gravity high could be caused by the eastern margin of the Blue Mountain thrust.

\section{Ground Water}

That portion of the Escalante Desert investigated is underlain by consolidated rocks of Cambrian to Tertiary age as well as by unconsolidated to semiconsolidated rocks of Quaternary age. Mower (1981) has combined these lithologic units into three hydrologic units. Unit 1 consists of Quaternary unconsolidated to semiconsolidated gravel, sand, silt, and clay and forms most of what is considered to be the principal ground-water reservoir. The thickness of these deposits is estimated by Mower (1981) to be no greater than $1000 \mathrm{ft}(305 \mathrm{~m})$ although Win Pe's (1980) gravity modelling indicates a much greater depth. Unit 2 consists of Tertiary andesitic latitic ignimbrites and is an undeveloped part of the principal groundwater reservoir. This unit has an estimated maximum thickness of $500 \mathrm{ft}(152 \mathrm{~m})$. Unit 3 consists of Quaternary to Cambrian age limestone, siltstone, shale, sandstone, basalt, intrusive igneous rocks as well as unconsolidated to semiconsolidated sedimentary deposits and constitutes the remainder of the drainage basin. Table 1 presents a more complete hydrologic description of the units and Figure 6 depicts their areal extent.

Recharge to the principal ground-water reservoir totals approximately 48,000 acre-feet $\left(59 \mathrm{hm}^{3}\right)$ annually. Of this, 31,000 acre-feet $\left(38 \mathrm{hm}^{3}\right)$ is obtained by subsurface inflow from bedrock as well as surface and subsurface inflow from stream channels (Mower, 1981). The remaining 16,000 acre-feet (21 $\mathrm{hm}^{3}$ ) of recharge is received from irrigation, from direct precipitation, and from inflow outside the drainage basin.

Prior to the construction of wells for irrigation (before 1960), ground water in the principal aquifer migrated from the main recharge areas at the periphery of the valley floor to discharge areas extending to the Milford area. Significant increases in pumping for irrigation has modified this flow pattern, resulting in an artificial ground-water boundary which extends northwest from a point northeast of Beryl Junction to a point northwest of Beryl (Figure 7). Primarily, ground water southwest of this boundary discharges in a large depression located in the vicinity of Beryl Junction; ground water northeast of the artificial boundary discharges, as before, to the northeast into the Milford area.

The direction of movement within the principal aquifer is generally from deeper zones of greater hydrostatic pressure through semiconsolidated beds to shallower zones of lesser pressure (Mower, 1981). Locally, however, this may be reversed if pumping has decreased the hydrostatic pressure sufficiently in the deeper zones, or if local recharge has increased the hydrostatic pressure sufficiently in the shallow zones.

\section{KNOWN GEOTHERMAL AREAS Thermo Hot Springs}

Thermo Hot Springs is located within that portion of the Escalante Valley included in this study. The springs issue along the sides and top of two NNEtrending en echelon calcareous travertine mounds that rise approximately $20 \mathrm{ft}(6 \mathrm{~m})$ above the valley floor (Mundorff, 1970). The southern mound, which has the most active spring system, is about $0.5 \mathrm{mi}$ $(0.8 \mathrm{~km})$ long and from 856 to $905 \mathrm{ft}(261-276 \mathrm{~m})$ in width. UGMS personnel recorded temperatures at the springs ranging from 42 to $78^{\circ} \mathrm{C}\left(108\right.$ to $\left.172^{\circ} \mathrm{F}\right)$.

The warm water issuing from the springs in the alluvium is thought to be meteoric, originating in the faulted mountains to the northwest or southeast (Mundorff, 1970). Thermo Hot Springs is thought to be at the site of intersecting, orthogonal faults which provide the conduits through which the heated meteoric water migrates from depth (Rowley, 1975).

Rush (1977) reported anomalously high thermal gradients for several shallow wells in the Thermo Hot Springs area. Two wells, 103 and $105 \mathrm{ft}$ (31.5 and 32 $m)$ in depth, adjacent to the springs exhibited gradients of 537 and $323^{\circ} \mathrm{C} / \mathrm{km}$, respectively. These gradients are constant throughout both profiles and could represent lateral flow in a near surface aquifer, and thus do not necessarily reflect temperatures to be expected at depth. The maximum temperatures recorded in these two wells were $28.4^{\circ} \mathrm{C}\left(83^{\circ} \mathrm{F}\right)$, $\left(537^{\circ} \mathrm{C} / \mathrm{km}\right.$ well) and $21.7^{\circ} \mathrm{C}\left(71^{\circ} \mathrm{F}\right),\left(323^{\circ} \mathrm{C} / \mathrm{km}\right.$ well).

\section{TEMPERATURE SURVEY}

Ground-water temperatures in the Escalante 


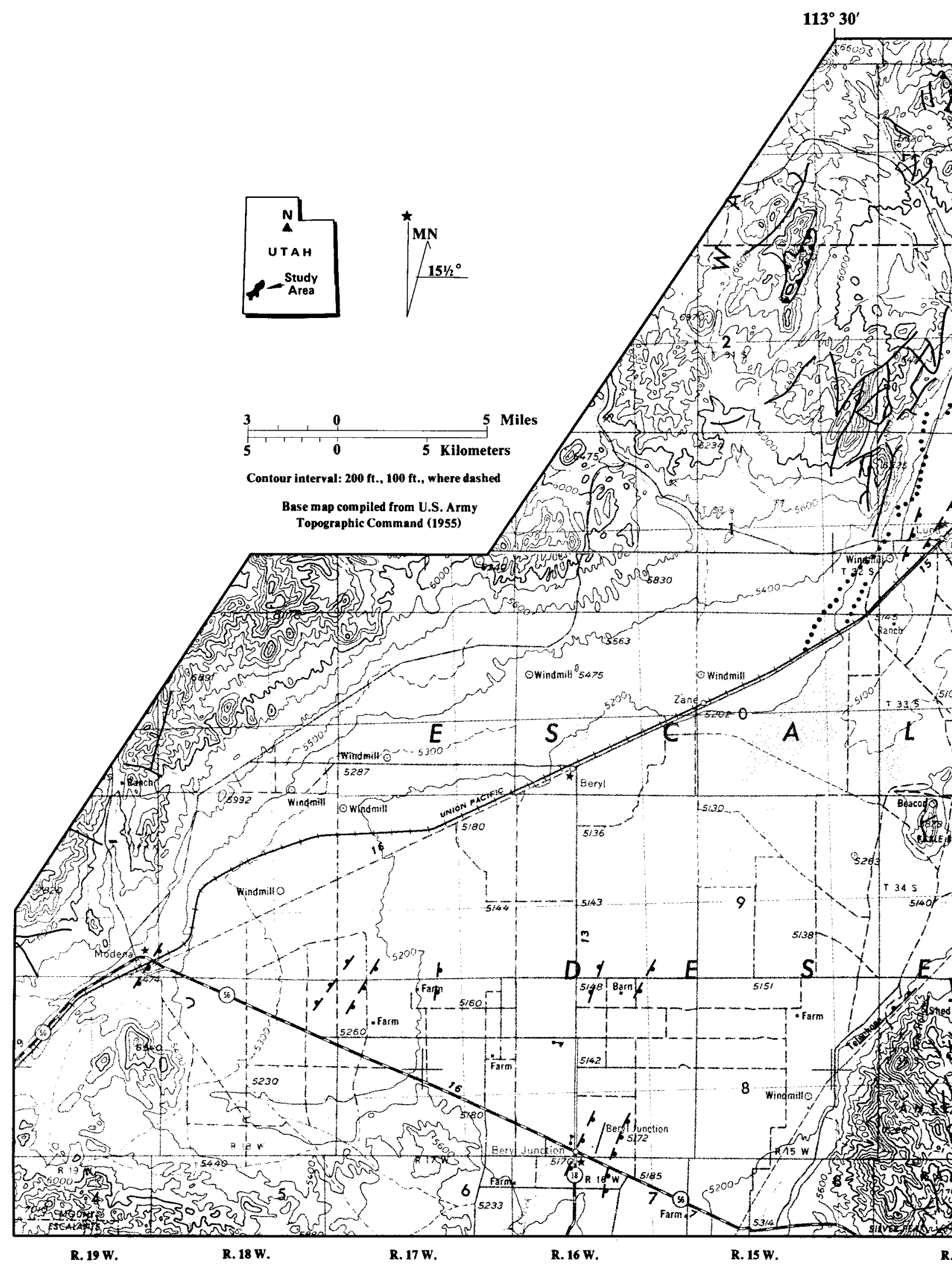


R.13w.

R. $12 \mathbf{W}$.

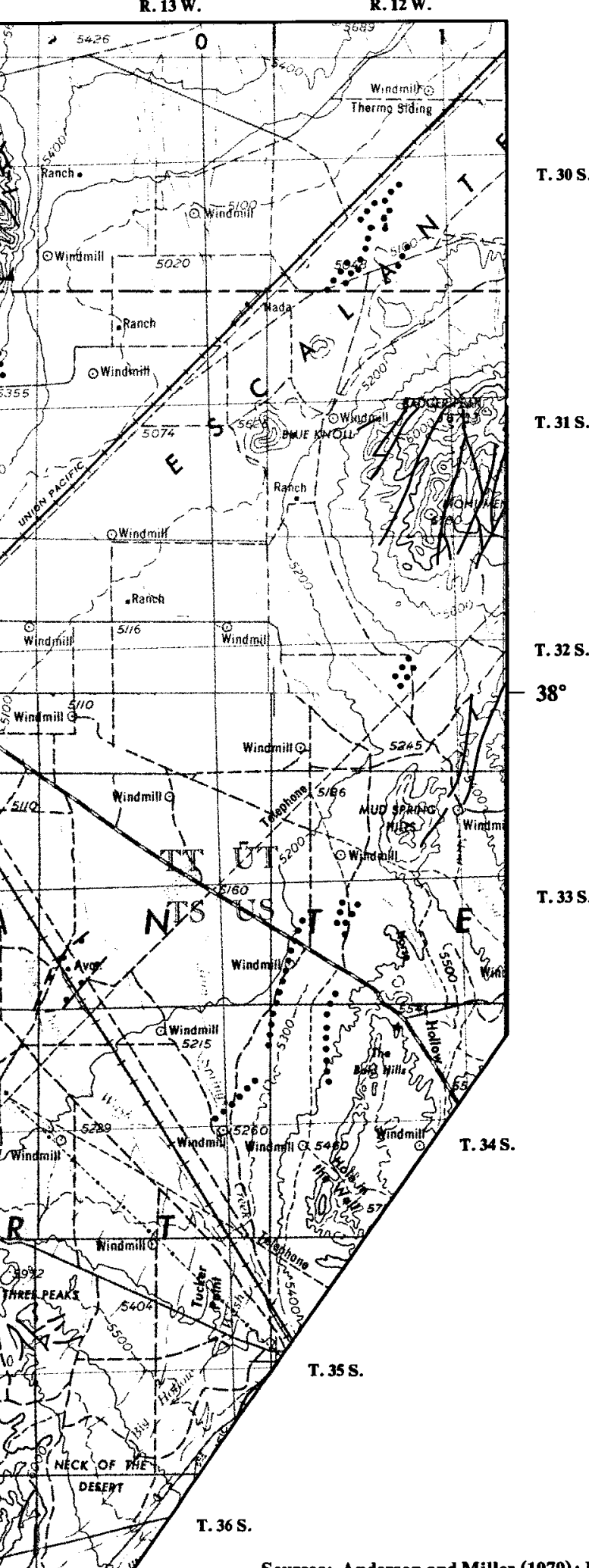

Figure 4.

Fault map of the Escalante Valley, Iron and Beaver Counties, Utah.

\section{EXPLANATION}

Fault, solid line where well exposed dashed where inferred

Suspected Quaternary faults

Blue Mountain thrust fault

Concealed fault, inferred by gravity dots on down-thrown side

Sources: Anderson and Miller (1979); Hintze (1963); Win Pe (1980) 


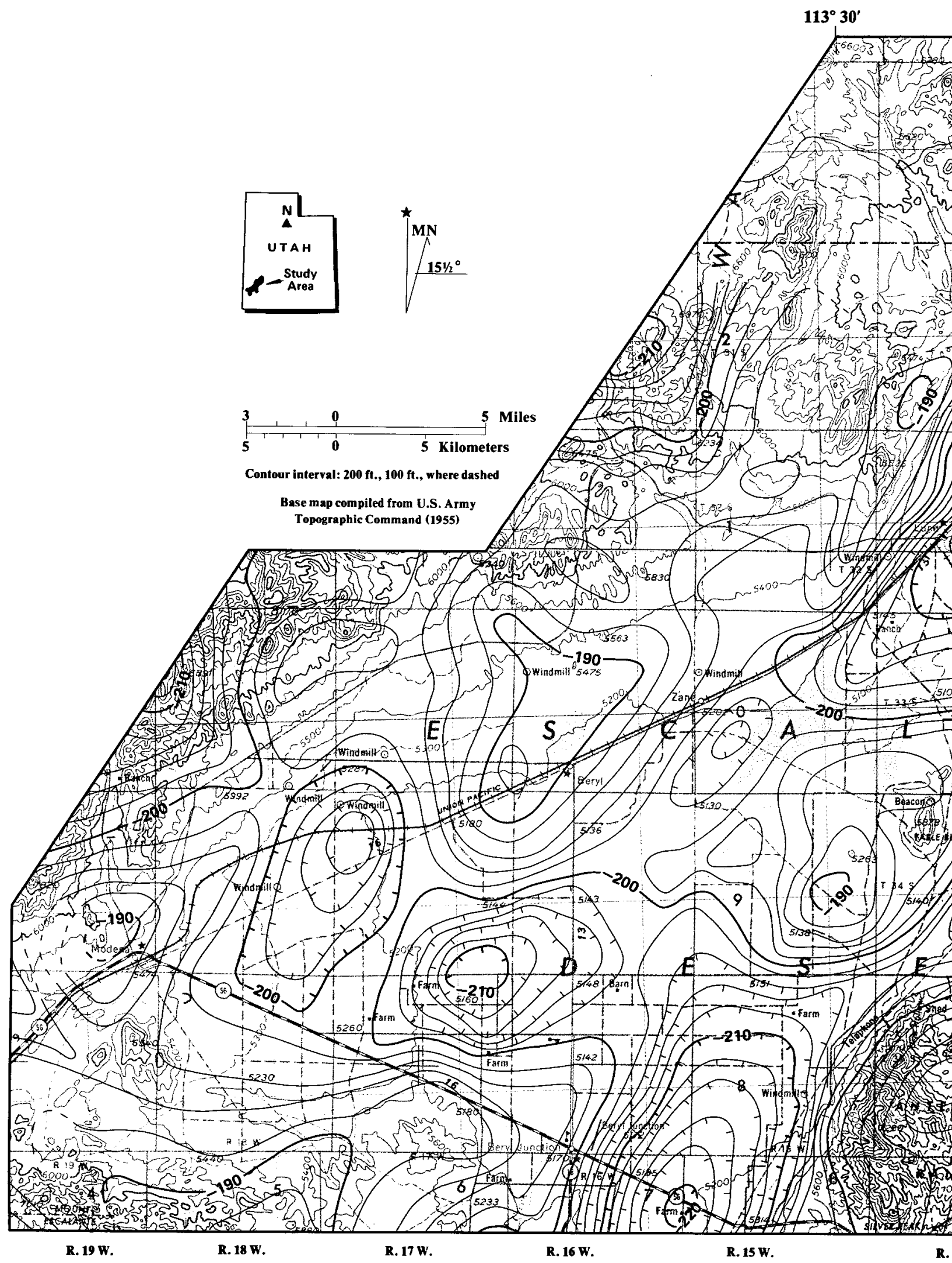




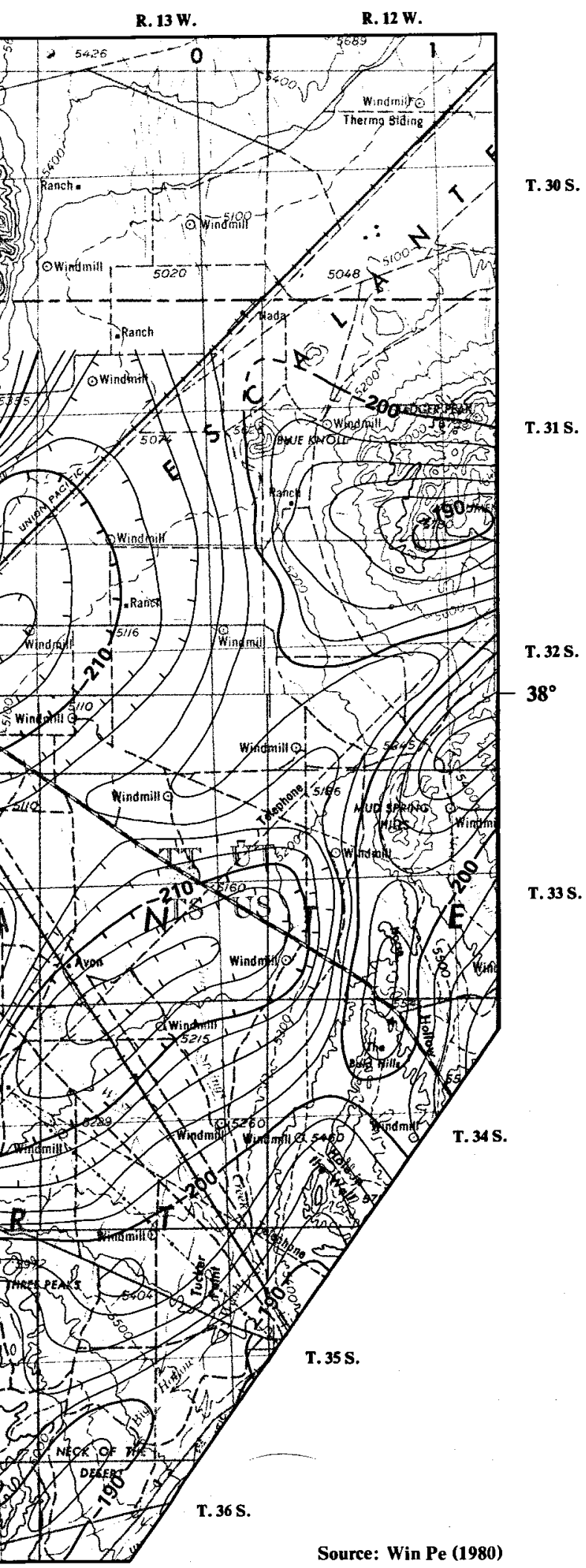

Figure 5.

Complete Bouguer gravity map of the Escalante Valley, Iron and Beaver Counties, Utah.

\section{EXPLANATION}

Gravity contour interval - 2 milligals 


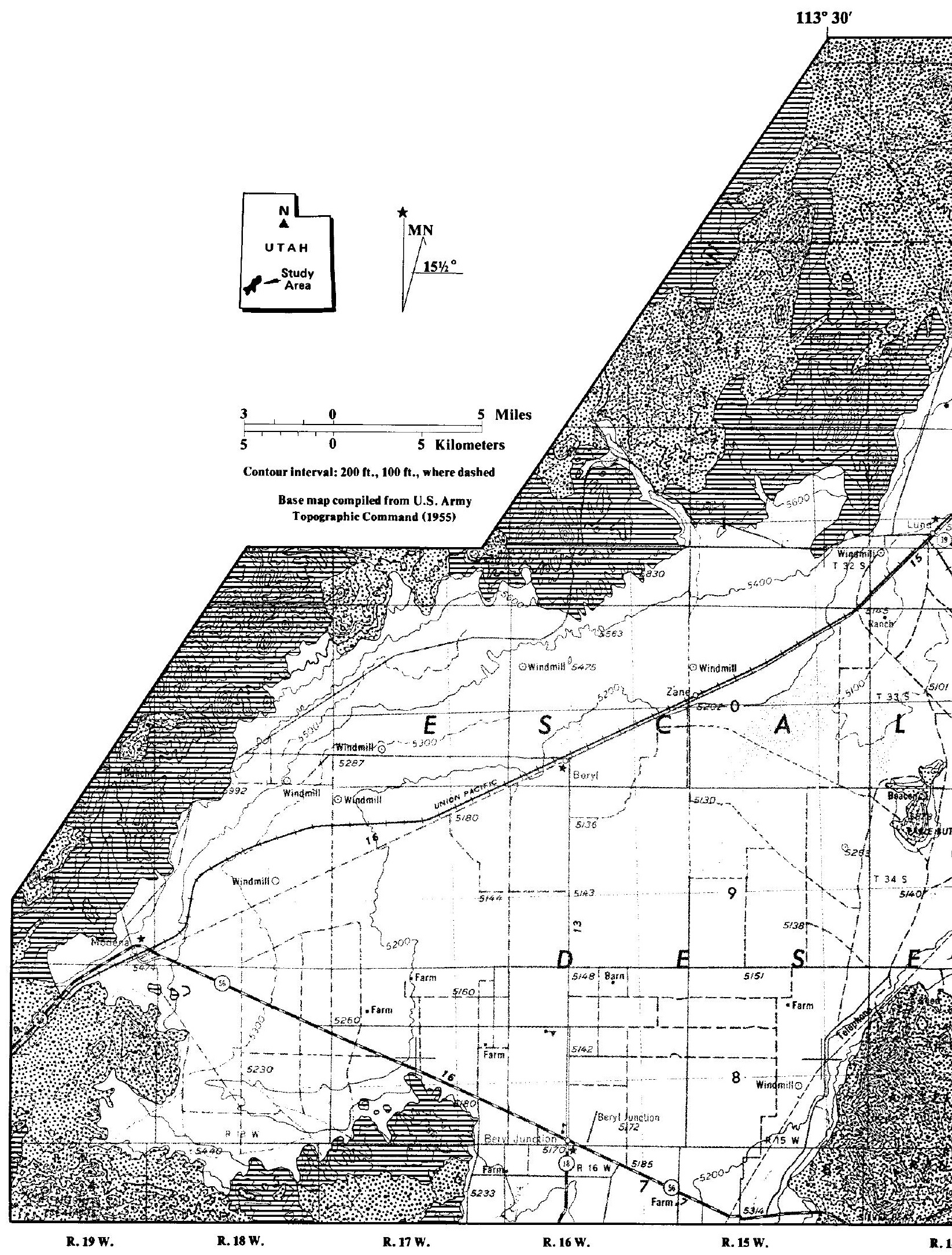




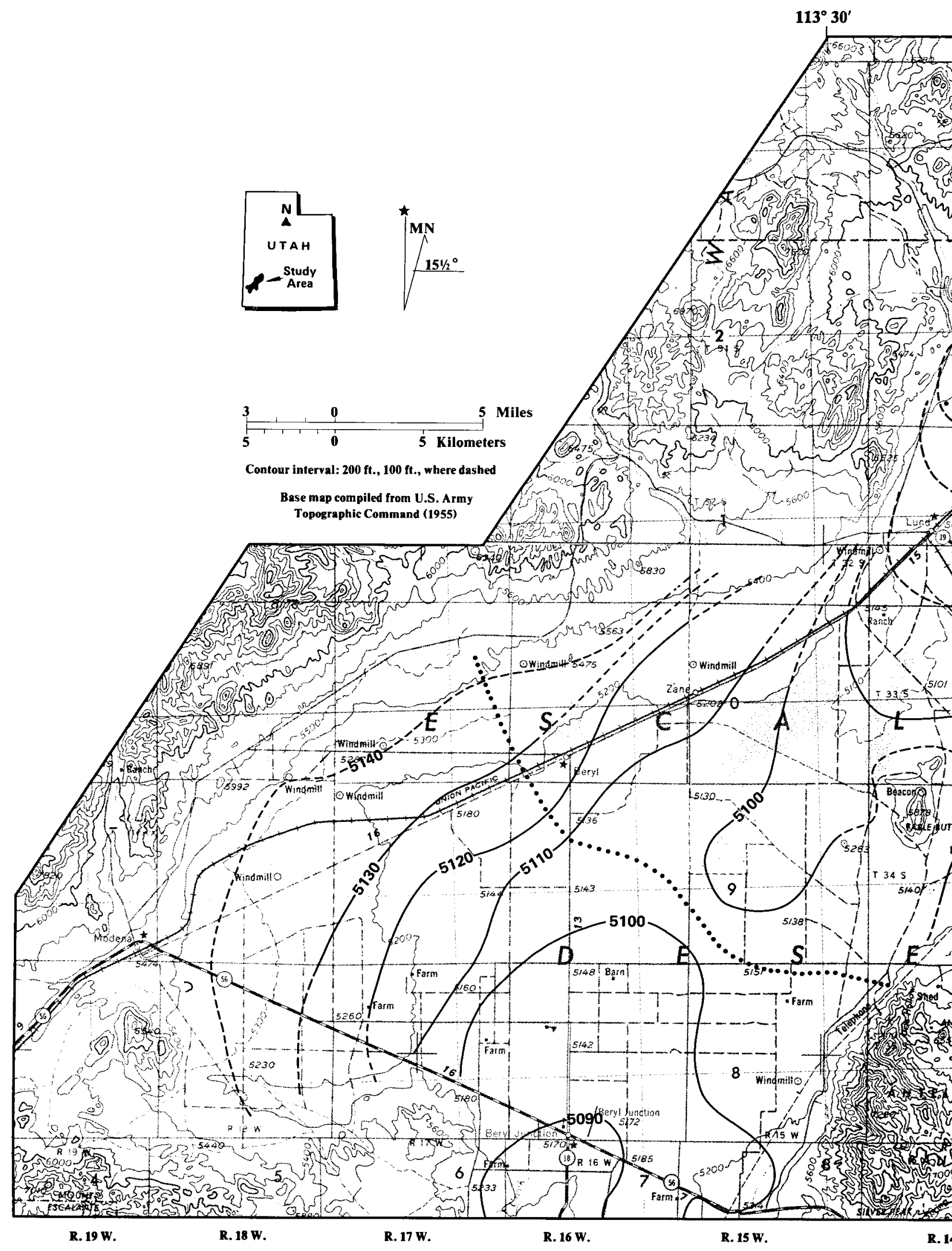


Table 1. Hydrogeologic units and their qualitative hydrologic properties (from Mower, 1981).

\begin{tabular}{ccl}
\hline \hline \multicolumn{3}{c}{ Hydrogeologic units } \\
\hline Unit & Geologic age & \multicolumn{1}{c}{ Lithology } \\
\hline 1 & Quaternary & $\begin{array}{l}\text { Unconsolidated to } \\
\text { semi-consolidated gravel, sand, } \\
\end{array}$ \\
& & silt, and clay.
\end{tabular}

Andesitic-latitic ignimbrite

Limestone, siltstone shale, sandstone, basalt, intrusive igneous rocks, unconsolidated to semi-consolidated sedimentary deposits.

\section{Qualitative hydrologic properties}

Forms most of the principal ground-water reservoir. Coarse- grained deposits, which crop out mainly around the perimeter of the area, probably accept large quantities of recharge from ephemeral flow resulting from storms. The sand and gravel, which generally are within 152 meters of the surface, readily yield water to wells. Clay and silt deposits restrict vertical movement, but they are not so extensive or impermeable as to prevent vertical movement between the coarser deposits. Thickness ranges from zero near the edge of the valley to probably more than 305 meters in the central part of the valley. The semiconsolidated deposits generally form the lowermost part of the principal ground-water reservoir. The semi-consolidated deposits are similar in most respects to the overlying unconsolidated deposits and usually it is difficult to distinguish between them.

Between Modena and Enterprise considered as an undeveloped part of the principal ground- water reservoir. Probably accepts a moderate rate of recharge where fracture zones underlie saturated, unconsolidated deposits or are crossed by ephemeral streams. Would yield water to wells at varying rates depending upon the number and interconnection of the fractures intersected.

Bounds the principal ground-water reservoir. The Quaternary. unconsolidated materials are thin surficial deposits; in places the older rocks contain well developed and interconnected open joints. Probably accepts moderate to large quantities of recharge and contributes large quantities of water to the principal ground-water reservoir at the southern margin of the valley and small to moderate quantities at the other margins. Would yield water to wells at varying rates, depending upon the number and interconnection of the fractures intersected. 
Valley vary both areally and with depth. Wells are screened through most of the saturated section penetrated, and therefore temperatures recorded at the well head are an approximate average for the entire perforated section (Mower, 1981).

Temperatures ranging from 12 to $78^{\circ} \mathrm{C}$ ( 54 to $172^{\circ} \mathrm{F}$ ) were measured at 53 wells and springs in the study area with a Yellow Springs Instrument (YSI) Model 33 Temperature-Conductivity Meter (Figure 8). All water wells measured were less than $410 \mathrm{ft}$ $(125 \mathrm{~m})$ in depth. Excluding four temperatures recorded at Thermo Hot Springs $\left(42\right.$ to $78^{\circ} \mathrm{C}$ or 108 to $\left.172^{\circ} \mathrm{F}\right)$ and a $60^{\circ} \mathrm{C}\left(140^{\circ} \mathrm{F}\right)$ temperature recorded at a $3072 \mathrm{ft}(2461 \mathrm{~m})$ geothermal test well $6.2 \mathrm{mi}(10$ $\mathrm{km})$ southwest of Zane, all temperatures of $20^{\circ} \mathrm{C}$ $\left(68^{\circ} \mathrm{F}\right)$ or greater were recorded northwest of the Union Pacific railroad line (Figure 8). Of those temperatures above $20^{\circ} \mathrm{C}\left(68^{\circ} \mathrm{F}\right)$, the warmest $(27$ and $28^{\circ} \mathrm{C}$ or 81 and $82^{\circ} \mathrm{F}$ ) are located northwest of Zane.

Six wells, with water temperatures of $20^{\circ} \mathrm{C}\left(68^{\circ} \mathrm{F}\right)$ or higher northwest of the Union Pacific railroad line were completed in what Mower (1981) describes as the principal aquifer. Well driller logs, which were available for only three of these wells, indicate screening only in the sand and gravel layers. Recharge to this area is from the northwest. Indications are, therefore, that the warm water encountered has its source somewhere to the northwest and these wells are intercepting lateral flow down gradient.

Of the remaining two warm wells $\left(20^{\circ} \mathrm{C}\right.$ or $\left.68^{\circ} \mathrm{F}\right)$, one was completed in what Mower (1981) refers to as Unit 2 (an undeveloped part of the principal groundwater reservoir). The material consists of andesitic and latitic ignimbrites. This well was drilled horizontally $148 \mathrm{ft}(45 \mathrm{~m})$ into Unit 2 . The other well was drilled at the mouth of Fishers Wash and is considered to be intersecting underflow from the wash.

\section{WATER CHEMISTRY}

Forty-nine water samples were collected and analyzed as part of this study (see Figure 9 for sample locations). The on-site analyses consisted of: (1) $\mathrm{pH}$, (2) alkalinity, and (3) conductivity. A Corning-Orion Model 407A/F specific ion meter in conjunction with an Orion gel-filled Model 91-05 combination pH electrode was used to measure $\mathrm{pH}$. Three readings were taken and the average was recorded as the final value. A YSI Model 33 Temperature-Conductivity Meter was used to measure conductivity. Alkalinity was measured using a Hach Alkalinity model AL-AP test kit.

Three polyethylene bottles (two $570 \mathrm{ml}$ and one 65 $\mathrm{ml}$ ) were filled at each sampling location with water filtered through a GeoFilter Peristaltic Pump - Model no. 004 using a 0.45 micron filter paper. That water was subsequently analyzed at the University of Utah Research Institute/Earth Science Laboratory (UURI/ESL). The $65 \mathrm{ml}$ bottle was acidified with reagent grade $\mathrm{HNO}_{3}$ to a final concentration of $20 \%$ $\mathrm{HNO}_{3}$ for cation analysis of elements presented in Table 2 by an APL Inductivity Coupled Plasma Quantometer (ICPQ). A $570 \mathrm{ml}$ bottle was acidified with concentrated $\mathrm{HCl}$ to a final concentration of 1 percent $\mathrm{HCl}$ for $\mathrm{S}_{4}$ analysis. The remaining bottle was unacidified and the water was analyzed for $\mathrm{Cl}, \mathrm{F}$, and total dissolved solids (TDS). Results of the analyses are presented in Table 3.

Table 2. Limits of quantitative determination (LQD) for solution analysis by the University of Utah

Research Institute/Earth Science Lab Inductively Coupled Plasma Quantometer.

\begin{tabular}{cc}
\hline \hline Element & Concentration (mg/) \\
\hline $\mathrm{Na}$ & 1.25 \\
$\mathrm{~K}$ & 2.50 \\
$\mathrm{Ca}$ & 0.250 \\
$\mathrm{Mg}$ & 0.500 \\
$\mathrm{Fe}$ & 0.025 \\
$\mathrm{Al}$ & 0.625 \\
$\mathrm{Si}$ & 0.250 \\
$\mathrm{Ti}$ & 0.125 \\
$\mathrm{P}$ & 0.625 \\
$\mathrm{Sr}$ & 0.013 \\
$\mathrm{Ba}$ & 0.625 \\
$\mathrm{~V}$ & 1.25 \\
$\mathrm{Cr}$ & 0.050 \\
$\mathrm{Mn}$ & 0.250 \\
$\mathrm{Co}$ & 0.025 \\
$\mathrm{Ni}$ & 0.125 \\
$\mathrm{Cu}$ & 0.063 \\
$\mathrm{Mo}$ & 1.25 \\
$\mathrm{~Pb}$ & 0.250 \\
$\mathrm{Zn}$ & 0.125 \\
$\mathrm{Cd}$ & 0.063 \\
$\mathrm{As}$ & 0.625 \\
$\mathrm{Sb}$ & 0.750 \\
$\mathrm{Bi}$ & 2.50 \\
$\mathrm{Sn}$ & 0.125 \\
$\mathrm{~W}$ & 0.125 \\
$\mathrm{Li}$ & 0.050 \\
$\mathrm{Be}$ & 0.005 \\
$\mathrm{~B}$ & 0.125 \\
$\mathrm{Zr}$ & 0.125 \\
$\mathrm{La}$ & 0.125 \\
$\mathrm{Ce}$ & 0.250 \\
$\mathrm{Th}$ & 2.50 \\
\hline
\end{tabular}

Note: LQD concentrations represent the lowest reliable analytic values for each element. Precision at the LQD is approximately \pm $100 \%$ of the given value with a confidence level of 95 percent. 


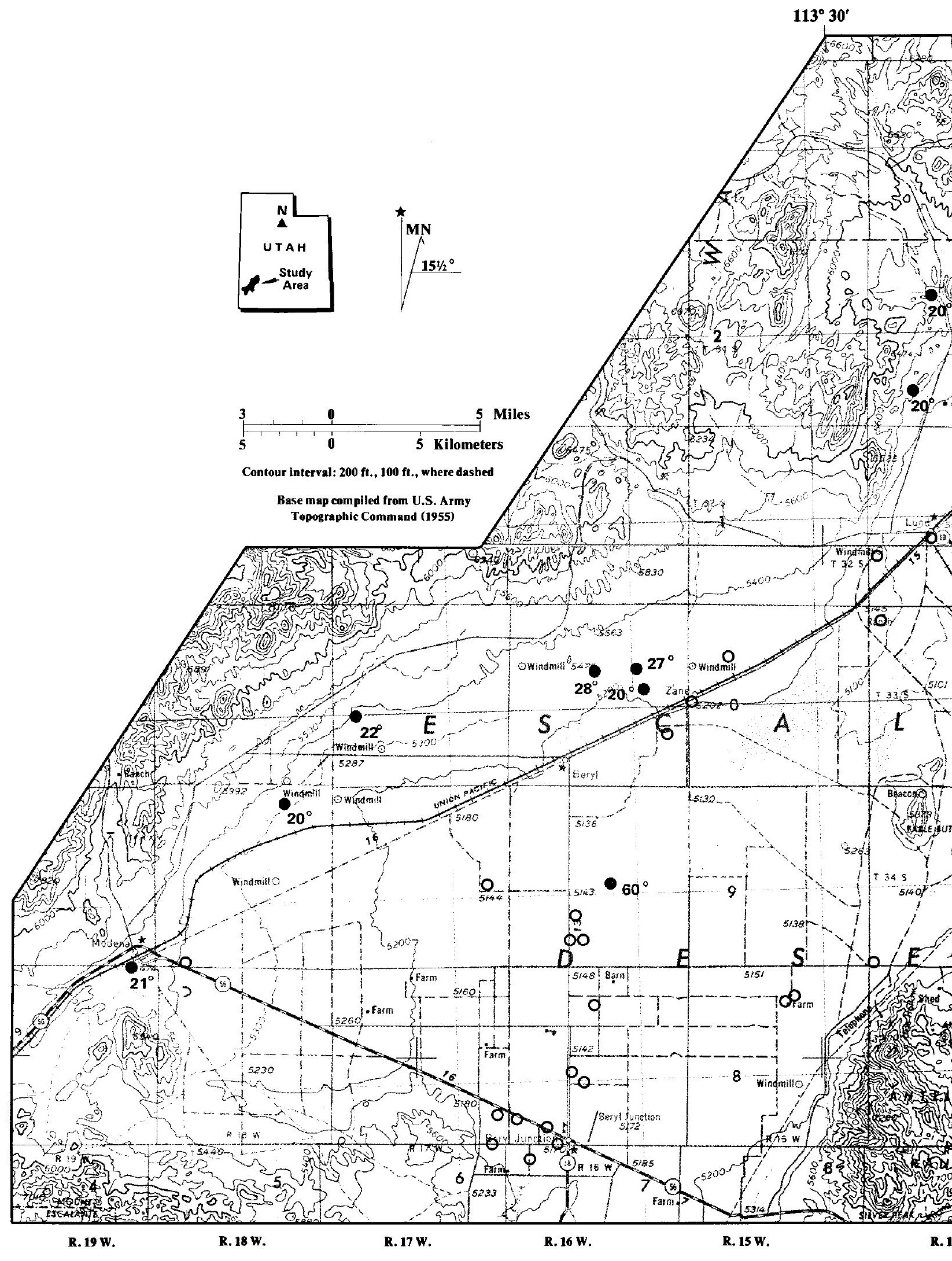


R.13 W.

R. $12 \mathbf{W}$.

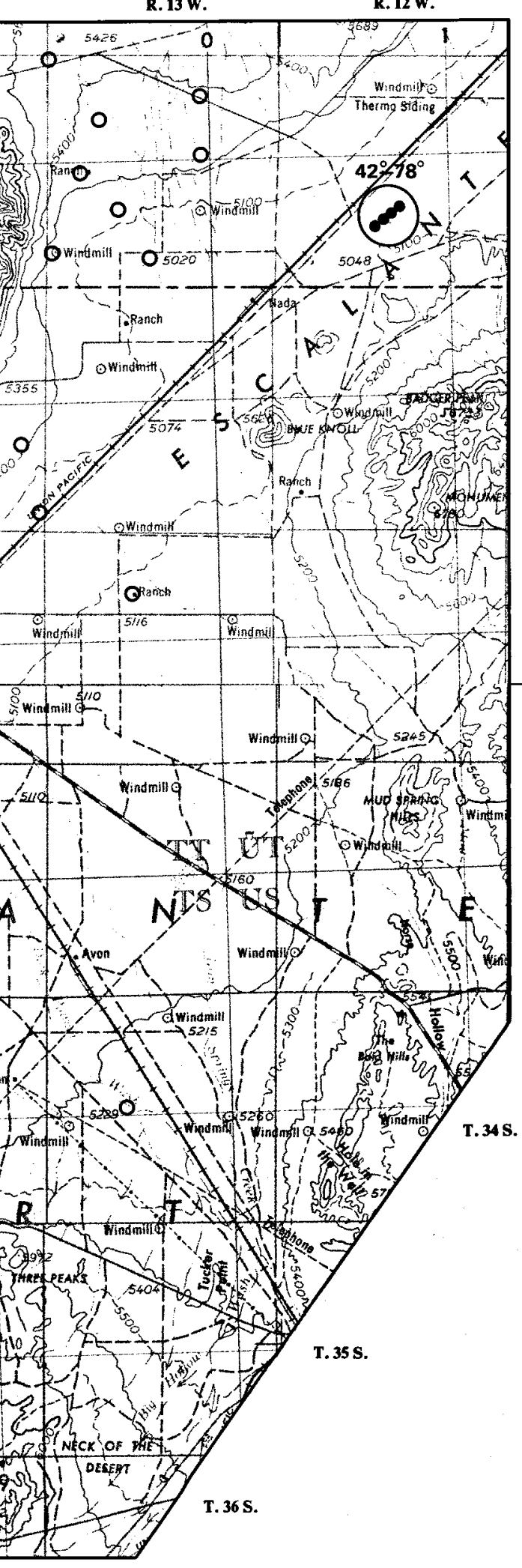

Figure 8.

T. 30 s. Ground-water temperature map of the Escalante Valley, Iron and Beaver Counties, Utah.

T.31 S.

\author{
EXPLANATION \\ O Temperatures $<20^{\circ} \mathrm{C}$ \\ (P) Thermo Hot Springs area \\ - Temperatures $\geqslant 20^{\circ} \mathrm{C}$
}

$38^{\circ}$

T. 33 S. 


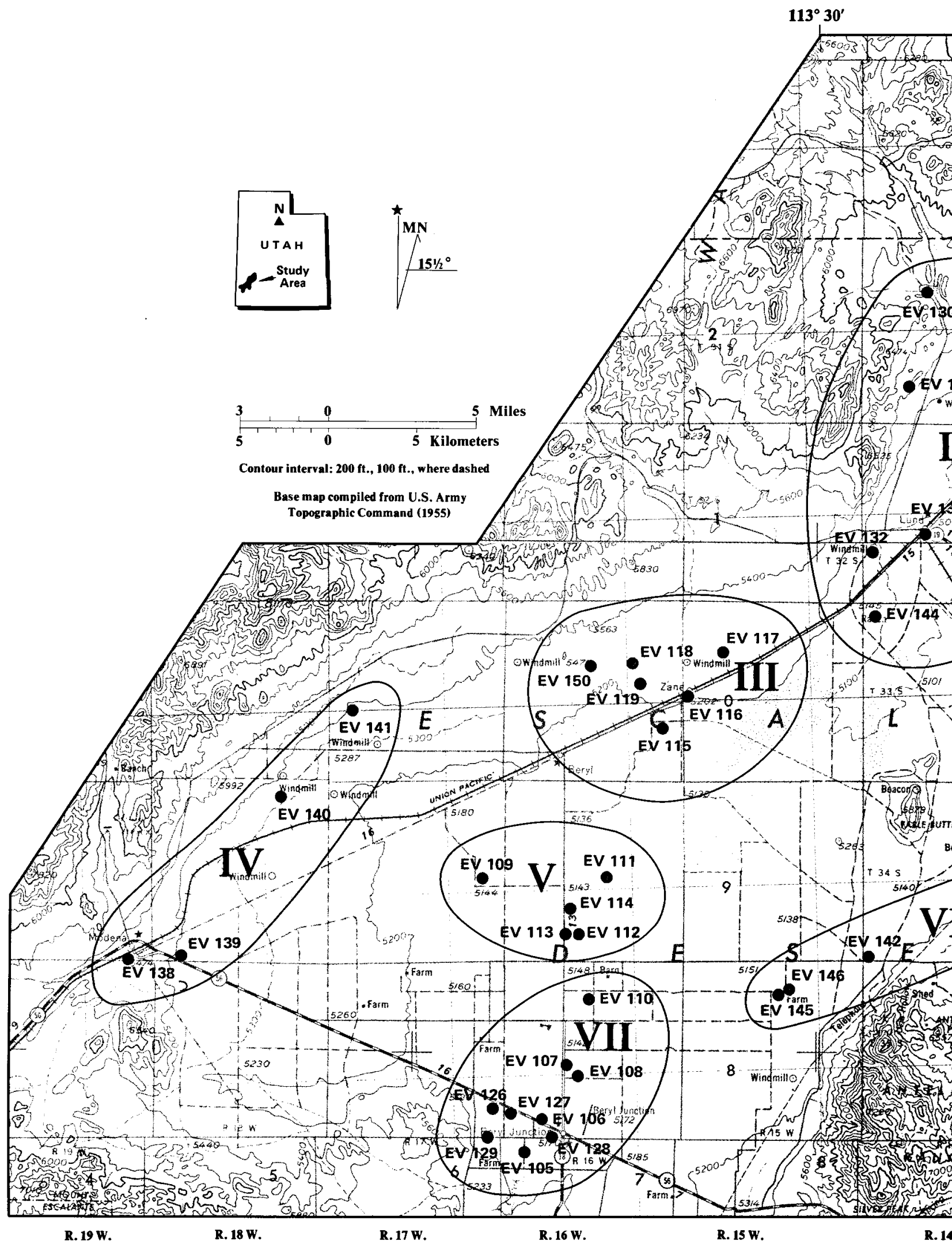


R.13 W.

R. 12 W.

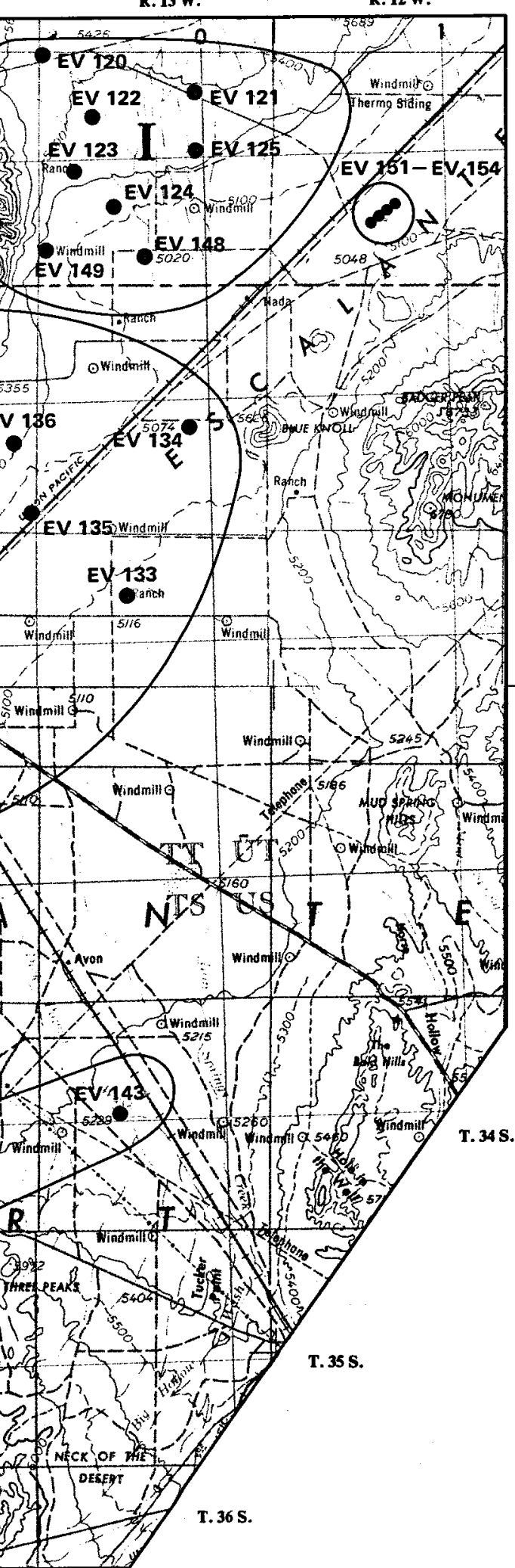

Figure 9.

r. 30 s. Well and spring chemistry sample locations Escalante Valley, Iron and Beaver Counties, Utah.

\section{EXPLANATION}

- Well locations

T. $32 \mathrm{~S}$. $38^{\circ}$

Thermo Hot Springs area

T Area and area numbers of grouped samples 
Table 3. Water analysis from wells and springs in the Escalante Valley, Utah.

\begin{tabular}{|c|c|c|c|c|c|c|c|}
\hline Sample No. & EV-105 & EV-106 & EV-107 & EV-108 & EV-109 & EV-110 & EV-111 \\
\hline Location & $\begin{array}{c}\text { (C- 36-16) } 5 b b c \\
37^{\circ} 42^{\prime} 03^{\prime \prime} \\
113^{\circ} 41^{\prime} 00^{\prime \prime} \\
\end{array}$ & $\begin{array}{c}\text { (C-35-16) 32bdb } \\
37^{\circ} 43^{\prime} 04^{\prime \prime} \\
113^{\circ} 40^{\prime} 03^{\prime \prime} \\
\end{array}$ & $\begin{array}{c}(\mathrm{C}-35-16) 21 \mathrm{bcc} \\
37^{\circ} 44^{\prime} 38^{\prime \prime} \\
113^{\circ} 39^{\prime} 13^{\prime \prime}\end{array}$ & $\begin{array}{c}\text { (C-35-16) 21dce } \\
37^{\circ} 44^{\prime} 13^{\prime \prime} \\
113^{\circ} 38^{\prime} 45^{\prime \prime}\end{array}$ & $\begin{array}{c}\text { (C-34-17) 24bac } \\
37^{\circ} 50^{\prime} 09^{\prime \prime} \\
113^{\circ} 42^{\prime} 18^{\prime \prime}\end{array}$ & $\begin{array}{c}(C-35-16) 9 \mathrm{aad} \\
37^{\circ} 46^{\prime} 36^{\prime \prime} \\
113^{\circ} 37^{\prime} 03^{\prime \prime}\end{array}$ & $\begin{array}{c}(\mathrm{C}-34-16) 22 \mathrm{baa} \\
37^{\circ} 50^{\prime} 42^{\prime \prime} \\
113^{\circ} 37^{\prime} 42^{\prime \prime}\end{array}$ \\
\hline Temp. ${ }^{\circ} \mathrm{C}$ & 14 & 16 & 14 & 14 & 17 & 12 & 60 \\
\hline pH & 7.45 & 7.80 & 7.65 & 7.85 & 7.90 & 7.55 & 9.10 \\
\hline tds (mg/l) & 536 & 288 & 416 & 330 & 318 & 604 & 446 \\
\hline $\mathrm{HCO}_{3}(\mathrm{mg} / \mathrm{l})$ & 275 & 209 & 275 & 217 & 183 & 234 & 259 \\
\hline $\mathrm{Na}(\mathrm{mg} / 1)$ & 22 & 17 & 18 & 17 & 25 & 21 & 148 \\
\hline $\mathrm{K}(\mathrm{mg} / \mathrm{l})$ & 7 & 5 & 5 & 4 & 8 & 6 & 3 \\
\hline $\mathrm{Ca}(\mathrm{mg} / \mathrm{l})$ & 123 & 53 & 76 & 60 & 68 & 118 & 5 \\
\hline $\mathrm{SiO}_{2}(\mathrm{mg} / \mathrm{l})$ & 44 & 43 & 41 & 41 & 54 & 41 & 54 \\
\hline $\mathrm{Mg}(\mathrm{mg} / \mathrm{l})$ & 23 & 10 & 15 & 12 & 9 & 20 & $\mathbf{u}$ \\
\hline $\mathrm{Fe}(\mathrm{mg} / \mathrm{l})$ & 0.04 & 0.06 & $\mathbf{u}$ & 0.03 & 0.14 & 0.13 & 0.06 \\
\hline $\mathrm{Ti}(\mathrm{mg} / \mathrm{l})$ & $\mathbf{u}$ & $\mathbf{u}$ & $\mathbf{u}$ & $\mathbf{u}$ & $\mathbf{u}$ & $\mathbf{u}$ & $\mathbf{u}$ \\
\hline Sr $(\mathrm{mg} / 1)$ & 0.66 & 0.31 & 0.38 & 0.29 & 0.43 & 0.50 & $\mathbf{u}$ \\
\hline$W(\mathrm{mg} / \mathrm{l})$ & $\mathbf{u}$ & $\mathrm{u}$ & $\mathbf{u}$ & $\mathbf{u}$ & $\mathbf{u}$ & $\mathbf{u}$ & 0.20 \\
\hline $\mathrm{Mn}(\mathrm{mg} / \mathrm{l})$ & $\mathbf{u}$ & $\mathbf{u}$ & $\mathbf{u}$ & $\mathbf{u}$ & $\mathbf{u}$ & $\mathbf{u}$ & $\mathbf{u}$ \\
\hline $\mathrm{Zn}(\mathrm{mg} / \mathrm{l})$ & $\mathbf{u}$ & $\mathbf{u}$ & $\mathbf{u}$ & 0.2 & 0.4 & 0.6 & u \\
\hline $\mathrm{Li}(\mathrm{mg} / \mathrm{l})$ & $\mathbf{u}$ & $\mathbf{u}$ & $\mathbf{u}$ & $\mathrm{u}$ & 0.06 & $\mathbf{u}$ & 0.16 \\
\hline $\mathrm{B}(\mathrm{mg} / \mathrm{l})$ & $\mathbf{u}$ & $\mathbf{u}$ & $\mathbf{u}$ & $\mathrm{u}$ & $\mathbf{u}$ & $\mathbf{u}$ & 5.30 \\
\hline$F(\mathrm{mg} / \mathrm{l})$ & 0.3 & 0.5 & 0.3 & 0.3 & 0.6 & 0.3 & 34 \\
\hline $\mathrm{Cl}(\mathrm{mg} / \mathrm{l})$ & 131 & 38 & 55 & 43 & 20 & 118 & 26 \\
\hline $\mathrm{SO}^{4}(\mathrm{mg} / \mathrm{l})$ & 43 & 14 & 30 & 20 & 58 & 49 & 40 \\
\hline
\end{tabular}

$\mathrm{u}=$ Elements not present or not present in detectable concentrations.

Table 3. Continued.

\begin{tabular}{|c|c|c|c|c|c|c|c|}
\hline Sample No. & EV-112 & EV-113 & EV-114 & EV-115 & EV-116 & EV-117 & EV-118 \\
\hline Location & $\begin{array}{c}(\mathrm{C}-34-16) 28 \mathrm{dcc} \\
37^{\circ} 48^{\prime} 34^{\prime \prime} \\
113^{\circ} 39^{\prime} 14^{\circ}\end{array}$ & $\begin{array}{c}(C-34-16) 28 \mathrm{ccc} \\
37^{\circ} 48^{\prime} 34^{\prime \prime} \\
113^{\circ} 39^{\prime} 15^{\prime \prime}\end{array}$ & $\begin{array}{c}(C-34-16) 28 b a c \\
37^{\circ} 49^{\prime} 13^{\prime \prime} \\
113^{\circ} 37^{\prime} 03^{\prime \prime}\end{array}$ & $\begin{array}{c}\text { (C-33-16)25bba } \\
37^{\circ} 54^{\prime} 39^{\prime \prime} \\
113^{\circ} 35^{\prime} 47^{\prime \prime}\end{array}$ & $\begin{array}{c}(\mathrm{C}-33-15) 19 \mathrm{bba} \\
37^{\circ} 55^{\prime} 29^{\prime \prime} \\
113^{\circ} 34^{\prime} 42^{\prime \prime}\end{array}$ & $\begin{array}{c}(\mathrm{C}-33-15) 8 \mathrm{caa} \\
37^{\circ} 56^{\prime} 44^{\prime \prime} \\
113^{\circ} 33^{\prime} 20^{\prime \prime}\end{array}$ & $\begin{array}{c}(C-33-16) 11 \mathrm{cdc} \\
37^{\circ} 56^{\prime} 25^{\prime \prime} \\
113^{\circ} 36^{\prime} 52^{\prime \prime}\end{array}$ \\
\hline Temp. ${ }^{\circ} \mathrm{C}$ & 12 & 14 & 14 & 15 & 16 & 17 & 27 \\
\hline pH & 7.35 & 8.00 & 7.75 & 6.99 & 7.69 & 7.02 & 7.15 \\
\hline tds (mg/1) & 884 & 322 & 344 & 5360 & 1490 & 1700 & 1760 \\
\hline $\mathrm{HCO}_{3}(\mathrm{mg} / \mathrm{l})$ & 192 & 184 & 184 & 258 & 292 & 401 & 376 \\
\hline $\mathrm{Na}(\mathrm{mg} / 1)$ & 38 & 34 & 39 & 690 & 241 & 393 & 405 \\
\hline $\mathrm{K}(\mathrm{mg} / \mathrm{l})$ & 9 & 7 & 7 & 30 & 12 & 12 & 34 \\
\hline $\mathrm{Ca}(\mathrm{mg} / \mathrm{l})$ & 138 & 45 & 41 & 693 & 186 & 159 & 140 \\
\hline $\mathrm{SiO}_{2}(\mathrm{mg} / \mathrm{l})$ & 50 & 56 & 55 & 50 & 45 & 42 & 49 \\
\hline $\mathrm{Mg}$ (mg/l) & 27 & 9 & 9 & 131 & 30 & 24 & 18 \\
\hline $\mathrm{Fe}(\mathrm{mg} / \mathrm{l})$ & 0.04 & 0.07 & 0.03 & 0.10 & 0.21 & 0.42 & 0.03 \\
\hline $\mathrm{Ti}(\mathrm{mg} / \mathrm{l})$ & $\mathbf{u}$ & $\mathbf{u}$ & $\mathbf{u}$ & $\mathbf{u}$ & 0.2 & 0.2 & 0.2 \\
\hline $\mathrm{Sr}(\mathrm{mg} / \mathrm{l})$ & 0.98 & 0.40 & 0.42 & 8.28 & 1.13 & 0.99 & 2.51 \\
\hline $\mathrm{W}(\mathrm{mg} / \mathrm{l})$ & $\mathbf{u}$ & $\mathbf{u}$ & $\mathbf{u}$ & $\mathbf{u}$ & $\mathbf{u}$ & $\mathbf{u}$ & $\mathbf{u}$ \\
\hline $\mathrm{Mn}(\mathrm{mg} / \mathrm{l})$ & $\mathbf{u}$ & $\mathbf{u}$ & $\mathbf{u}$ & $\mathbf{u}$ & $\mathbf{u}$ & $\mathbf{u}$ & $\mathbf{u}$ \\
\hline $\mathrm{Zn}(\mathrm{mg} / \mathrm{l})$ & 0.3 & $\mathbf{u}$ & $\mathbf{u}$ & 0.2 & 0.4 & 0.4 & 0.2 \\
\hline $\mathrm{Li}(\mathrm{mg} / \mathrm{l})$ & $\mathbf{u}$ & $\mathbf{u}$ & $\mathbf{u}$ & 1.02 & 0.24 & 0.97 & 1.06 \\
\hline $\mathrm{B}(\mathrm{mg} / \mathrm{l})$ & $\mathbf{u}$ & $\mathrm{u}$ & $\mathbf{u}$ & 1.2 & 0.6 & 0.9 & 1.1 \\
\hline$F(m g / l)$ & 0.7 & 1.5 & 1.6 & 1.9 & 1.5 & 1.9 & 3.1 \\
\hline $\mathrm{Cl}(\mathrm{mg} / \mathrm{l})$ & 212 & 46 & 42 & 1674 & 346 & 419 & 447 \\
\hline $\mathrm{SO}^{4}(\mathrm{mg} / \mathrm{l})$ & 105 & 26 & 29 & 122 & 382 & 369 & 367 \\
\hline
\end{tabular}

$\mathbf{u}=$ Elements not present or not present in detectable concentrations. 
Table 3. Continued.

\begin{tabular}{|c|c|c|c|c|c|c|c|}
\hline Sample No. & EV-119 & EV-120 & EV-121 & EV-122 & EV-123 & EV-124 & EV-125 \\
\hline Location & $\begin{array}{c}\text { (C-33-16)14deb } \\
37^{\circ} 56^{\prime} 44^{\prime \prime} \\
113^{\circ} 38^{\prime} 12^{\prime \prime}\end{array}$ & $\begin{array}{c}(\mathrm{C}-30-13) 6 \mathrm{bbb} \\
37^{\circ} 14^{\prime} 11^{\prime \prime} \\
113^{\circ} 21^{\prime} 36^{\prime \prime}\end{array}$ & $\begin{array}{c}\text { (C-30-13)11bbb } \\
37^{\circ} 13^{\prime} 16^{\prime \prime} \\
113^{\circ} 17^{\prime} 12^{\prime \prime}\end{array}$ & $\begin{array}{c}(\mathrm{C}-30-13) 8 \text { baa } \\
37^{\circ} 12^{\prime} 49^{\prime \prime} \\
113^{\circ} 20^{\prime} 00^{\prime \prime}\end{array}$ & $\begin{array}{c}\text { (C-30-13) 18ddd } \\
37^{\circ} 11^{\prime} 34^{\prime \prime} \\
113^{\circ} 20^{\prime} 35^{\prime \prime}\end{array}$ & $\begin{array}{c}\text { (C-30-13) 20dda } \\
37^{\circ} 10^{\prime} 45^{\prime \prime} \\
113^{\circ} 19^{\prime} 32^{\prime \prime}\end{array}$ & $\begin{array}{c}\text { (C-30-13) 14bec } \\
37^{\circ} 11^{\prime} 58^{\prime \prime} \\
113^{\circ} 17^{\prime} 08^{\prime \prime}\end{array}$ \\
\hline Temp. ${ }^{\circ} \mathrm{C}$ & 20 & 18 & 16 & 18 & 15 & 15 & 16 \\
\hline pH & 7.05 & 8.10 & 7.90 & 7.80 & 7.60 & 7.61 & 7.80 \\
\hline $\mathrm{tds}(\mathrm{mg} / \mathrm{l})$ & 1730 & 276 & 426 & 326 & 594 & 514 & 643 \\
\hline $\mathrm{HCO}_{3}(\mathrm{mg} / \mathrm{l})$ & 351 & 158 & 217 & 167 & 167 & 200 & 138 \\
\hline $\mathrm{Na}(\mathrm{mg} / \mathrm{l})$ & 395 & 40 & 99 & 48 & 35 & 48 & 40 \\
\hline $\mathrm{K}(\mathrm{mg} / \mathrm{l})$ & 34 & $\mathbf{u}$ & $\mathbf{u}$ & $\mathbf{u}$ & 3 & 4 & 4 \\
\hline $\mathrm{Ca}(\mathrm{mg} / \mathrm{l})$ & 145 & 28 & 31 & 41 & 81 & 69 & 67 \\
\hline $\mathrm{SiO}_{2}(\mathrm{mg} / \mathrm{l})$ & 52 & 26 & 55 & 35 & 23 & 25 & 35 \\
\hline $\mathrm{Mg}(\mathrm{mg} / \mathrm{l})$ & 14 & 10 & 5 & 11 & 30 & 28 & 36 \\
\hline $\mathrm{Fe}(\mathrm{mg} / 1)$ & 0.05 & 0.08 & 0.10 & 0.10 & 0.04 & 0.05 & 0.05 \\
\hline $\mathrm{Ti}(\mathrm{mg} / \mathrm{l})$ & 0.2 & $\mathbf{u}$ & 1.10 & $\mathbf{u}$ & $\mathbf{u}$ & $\mathrm{u}$ & $\mathbf{u}$ \\
\hline $\mathrm{Sr}(\mathrm{mg} / \mathrm{l})$ & 2.13 & 0.39 & 0.35 & 0.82 & 1.11 & 1.08 & 1.22 \\
\hline W (mg/l) & $\mathbf{u}$ & $\mathbf{u}$ & $\mathbf{u}$ & $\mathbf{u}$ & $\mathbf{u}$ & $\mathbf{u}$ & $\mathbf{u}$ \\
\hline $\mathrm{Mn}(\mathrm{mg} / \mathrm{l})$ & $\mathbf{u}$ & $\mathbf{u}$ & $\mathbf{u}$ & $\mathbf{u}$ & $\mathbf{u}$ & $\mathbf{u}$ & $\mathbf{u}$ \\
\hline $\mathrm{Zn}(\mathrm{mg} / \mathrm{l})$ & 2.6 & 0.6 & 1.0 & 0.4 & 0.4 & 0.4 & 0.2 \\
\hline $\mathrm{Li}(\mathrm{mg} / \mathrm{l})$ & 1.07 & u & 0.1 & $\mathbf{u}$ & $\mathbf{u}$ & $\mathrm{u}$ & $\mathbf{u}$ \\
\hline $\mathrm{B}(\mathrm{mg} / \mathrm{l})$ & 1.0 & $\mathbf{u}$ & 0.5 & 0.2 & $\mathbf{u}$ & $\mathbf{u}$ & $\mathbf{u}$ \\
\hline$F(\mathrm{mg} / \mathrm{l})$ & 3.9 & 0.8 & 0.8 & 1.1 & 0.9 & 1.0 & 0.6 \\
\hline $\mathrm{Cl}(\mathrm{mg} / \mathrm{l})$ & 402 & 37 & 30 & 32 & 108 & 104 & 144 \\
\hline $\mathrm{SO}^{4}(\mathrm{mg} / \mathrm{l})$ & 376 & 20 & 77 & 53 & 112 & 85 & 94 \\
\hline
\end{tabular}

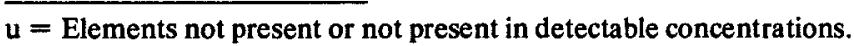

Table 3. Continued.

\begin{tabular}{|c|c|c|c|c|c|c|c|}
\hline Sample No. & EV-126 & EV-127 & EV-128 & EV-129 & EV-130 & EV-131 & EV-132 \\
\hline Location & $\begin{array}{c}\text { (C-35-17)25ded } \\
37^{\circ} 43^{\prime} 20^{\prime \prime} \\
113^{\circ} 41^{\prime} 53^{\prime \prime} \\
\end{array}$ & $\begin{array}{c}\text { (C-35-16)31bab } \\
37^{\circ} 43^{\prime} 15^{\prime \prime} \\
113^{\circ} 41^{\prime} 14^{\prime \prime} \\
\end{array}$ & $\begin{array}{c}\text { (C-35-16)32bdc } \\
37^{\circ} 42^{\prime} 12^{\prime \prime} \\
113^{\circ} 39^{\prime} 41^{\prime \prime} \\
\end{array}$ & $\begin{array}{c}\text { (C-35-17)36dec } \\
37^{\circ} 42^{\prime} 12^{\prime \prime} \\
113^{\circ} 42^{\prime} 02^{\prime \prime} \\
\end{array}$ & $\begin{array}{c}\text { (C-31-14)9bdb } \\
38^{\circ} 07^{\prime} 24^{\prime \prime} \\
113^{\circ} 24^{\prime} 11^{\prime \prime} \\
\end{array}$ & $\begin{array}{c}\text { (C-31-14) 29aac } \\
38^{\circ} 04^{\prime} 37^{\prime \prime} \\
113^{\circ} 26^{\prime} 21^{\prime \prime} \\
\end{array}$ & $\begin{array}{c}\text { (C-32-14) 30bab } \\
38^{\circ} 00^{\prime} 18^{\prime \prime} \\
113^{\circ} 27^{\prime} 30^{\prime \prime} \\
\end{array}$ \\
\hline Temp. ${ }^{\circ} \mathrm{C}$ & 14 & 14 & 14 & 16 & 20 & 20 & 18 \\
\hline $\mathrm{pH}$ & 7.20 & 7.25 & 7.10 & 7.55 & 7.08 & 7.09 & 7.11 \\
\hline tds $(\mathrm{mg} / \mathrm{l})$ & 492 & 446 & 610 & 268 & 482 & 724 & 1232 \\
\hline $\mathrm{HCO}_{3}(\mathrm{mg} / \mathrm{l})$ & 217 & 192 & 384 & 184 & 367 & 334 & 159 \\
\hline $\mathrm{Na}(\mathrm{mg} / \mathrm{l})$ & 30 & 18 & 20 & 21 & 51 & 60 & 104 \\
\hline $\mathrm{K}(\mathrm{mg} / \mathrm{l})$ & 5 & 6 & 6 & 5 & $\mathbf{u}$ & $\mathbf{u}$ & 6 \\
\hline $\mathrm{Ca}(\mathrm{mg} / \mathrm{l})$ & 85 & 70 & 138 & 43 & 95 & 123 & 165 \\
\hline $\mathrm{SiO}_{2}(\mathrm{mg} / \mathrm{l})$ & 41 & 48 & 35 & 40 & 42 & 33 & 32 \\
\hline $\mathrm{Mg}(\mathrm{mg} / \mathrm{l})$ & 15 & 13 & 23 & 8 & 17 & 27 & 53 \\
\hline $\mathrm{Fe}(\mathrm{mg} / \mathrm{l})$ & 0.03 & 0.06 & 0.15 & $\mathbf{u}$ & $\mathbf{u}$ & $\mathbf{u}$ & 0.20 \\
\hline $\mathrm{Ti}(\mathrm{mg} / \mathrm{l})$ & $\mathbf{u}$ & $\mathbf{u}$ & $\mathbf{u}$ & $\mathbf{u}$ & $\mathbf{u}$ & $\mathbf{u}$ & u \\
\hline $\mathrm{Sr}(\mathrm{mg} / \mathrm{l})$ & 0.53 & 0.41 & 0.56 & 0.26 & 0.57 & 1.06 & 1.56 \\
\hline W (mg/l) & $\mathbf{u}$ & $\mathbf{u}$ & $\mathbf{u}$ & $\mathbf{u}$ & $\mathbf{u}$ & $\mathbf{u}$ & $\mathbf{u}$ \\
\hline $\mathrm{Mn}(\mathrm{mg} / \mathrm{l})$ & $\mathbf{u}$ & $\mathbf{u}$ & $\mathbf{u}$ & $\mathbf{u}$ & $\mathbf{u}$ & $\mathbf{u}$ & $\mathbf{u}$ \\
\hline $\mathrm{Zn}(\mathrm{mg} / \mathrm{l})$ & 0.3 & 0.6 & 3.3 & $\mathbf{u}$ & $\mathbf{u}$ & $\mathbf{u}$ & 0.4 \\
\hline $\mathrm{Li}(\mathrm{mg} / \mathrm{l})$ & $\mathbf{u}$ & $\mathbf{u}$ & $\mathfrak{u}$ & $\mathbf{u}$ & $\mathbf{u}$ & $\mathbf{u}$ & 0.06 \\
\hline B (mg/l) & $\mathbf{u}$ & $\mathbf{u}$ & $\mathbf{u}$ & $\mathbf{u}$ & $\mathbf{u}$ & $\mathbf{u}$ & 0.2 \\
\hline F (mg/l) & 1.0 & 0.3 & 0.3 & 1.4 & 0.5 & 0.5 & 0.9 \\
\hline $\mathrm{Cl}(\mathrm{mg} / \mathrm{l})$ & 112 & 86 & 97 & 26 & 60 & 165 & 321 \\
\hline $\mathrm{SO}^{4}(\mathrm{mg} / \mathrm{l})$ & 24 & 13 & 37 & 14 & 24 & 54 & 219 \\
\hline
\end{tabular}

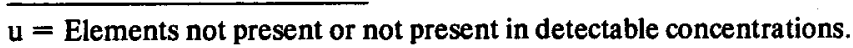


Table 3. Continued.

\begin{tabular}{|c|c|c|c|c|c|c|c|}
\hline Sample No. & EV-133 & EV-134 & EV-135 & EV-136 & EV-137 & EV-138 & EV-139 \\
\hline Location & $\begin{array}{c}\text { (C-32-13)9bdd } \\
38^{\circ} 02^{\prime} 06^{\prime \prime} \\
113^{\circ} 19^{\prime} 03^{\prime \prime} \\
\end{array}$ & $\begin{array}{c}(C-31-13) 23 b b b \\
38^{\circ} 05^{\prime} 59^{\prime \prime} \\
113^{\circ} 21^{\prime} 39^{\prime \prime} \\
\end{array}$ & $\begin{array}{c}\text { (C-31-13) 31bec } \\
38^{\circ} 03^{\prime} 56^{\prime \prime} \\
113^{\circ} 21^{\prime} 39^{\prime \prime} \\
\end{array}$ & $\begin{array}{c}\text { (C-31-14) } 24 \text { caa } \\
38^{\circ} 05^{\prime} 33^{\prime \prime} \\
113^{\circ} 22^{\prime} 18^{\prime \prime} \\
\end{array}$ & $\begin{array}{c}\text { (C-32-14) 21bed } \\
38^{\circ} 00^{\prime} 21^{\prime \prime} \\
113^{\circ} 25^{\prime} 56^{\prime \prime} \\
\end{array}$ & $\begin{array}{c}\text { (C-34-19) 31dcb } \\
38^{\circ} 47^{\prime} 53^{\prime \prime} \\
113^{\circ} 55^{\prime} 17^{\prime \prime} \\
\end{array}$ & $\begin{array}{c}\text { (C-34-18) 32ccb } \\
38^{\circ} 47^{\prime} 49^{\prime \prime} \\
113^{\circ} 53^{\prime} 32^{\prime \prime} \\
\end{array}$ \\
\hline Temp. ${ }^{\circ} \mathrm{C}$ & 14 & 13 & 14 & 17 & 19 & 21 & 16 \\
\hline pH & 7.40 & 7.12 & 7.33 & 7.40 & 7.62 & 7.45 & 8.01 \\
\hline tds (mg/l) & 617 & 2194 & 2480 & 770 & 402 & 478 & 372 \\
\hline $\mathrm{HCO}_{3}(\mathrm{mg} / \mathrm{l})$ & 208 & 292 & 200 & 159 & 234 & 250 & 209 \\
\hline $\mathrm{Na}(\mathrm{mg} / \mathrm{l})$ & 57 & 261 & 290 & 81 & 46 & 70 & 63 \\
\hline $\mathrm{K}(\mathrm{mg} / \mathrm{l})$ & 5 & 8 & 9 & 6 & 8 & 5 & 7 \\
\hline $\mathrm{Ca}(\mathrm{mg} / \mathrm{l})$ & 71 & 158 & 193 & 96 & 61 & 67 & 65 \\
\hline $\mathrm{SiO}_{2}(\mathrm{mg} / \mathrm{l})$ & 28 & 41 & 35 & 31 & 51 & 37 & 42 \\
\hline $\mathrm{Mg}(\mathrm{mg} / \mathrm{l})$ & 40 & 155 & 165 & 36 & 26 & 10 & 7 \\
\hline $\mathrm{Fe}(\mathrm{mg} / \mathrm{l})$ & $\mathbf{u}$ & 0.10 & 0.10 & 0.29 & 0.15 & 0.03 & 0.25 \\
\hline $\mathrm{Ti}(\mathrm{mg} / \mathrm{l})$ & $\mathbf{u}$ & $\mathrm{u}$ & $\mathbf{u}$ & $\mathbf{u}$ & $\mathbf{u}$ & $\mathbf{u}$ & u \\
\hline $\mathrm{Sr}(\mathrm{mg} / \mathrm{l})$ & 0.63 & 2.13 & 2.31 & 0.77 & 0.91 & 0.51 & 0.30 \\
\hline W (mg/l) & $\mathbf{u}$ & $\mathrm{u}$ & $\mathbf{u}$ & $\mathbf{u}$ & $\mathbf{u}$ & $\mathbf{u}$ & $\mathbf{u}$ \\
\hline $\mathrm{Mn}(\mathrm{mg} / \mathrm{l})$ & $\mathbf{u}$ & $\mathrm{u}$ & $\mathbf{u}$ & $\mathbf{u}$ & $\mathbf{u}$ & $\mathbf{u}$ & u \\
\hline $\mathrm{Zn}(\mathrm{mg} / \mathrm{l})$ & 0.8 & $\mathbf{u}$ & $\mathbf{u}$ & 0.2 & 0.7 & $\mathbf{u}$ & 1.4 \\
\hline $\mathrm{Li}(\mathrm{mg} / \mathrm{l})$ & $\mathbf{u}$ & 0.10 & 0.09 & $\mathbf{u}$ & 0.07 & 0.21 & 0.19 \\
\hline $\mathrm{B}(\mathrm{mg} / \mathrm{l})$ & $\mathbf{u}$ & 0.5 & 0.4 & 0.2 & 0.2 & 0.2 & 0.2 \\
\hline$F(\mathrm{mg} / \mathrm{l})$ & 0.5 & 0.7 & 0.7 & 0.7 & 1.3 & 2.5 & 2.6 \\
\hline $\mathrm{Cl}(\mathrm{mg} / \mathrm{l})$ & 74 & 290 & 533 & 135 & 53 & 58 & 33 \\
\hline $\mathrm{SO}^{4}(\mathrm{mg} / \mathrm{l})$ & 218 & 973 & 870 & 245 & 61 & 97 & 64 \\
\hline
\end{tabular}

$\mathrm{u}=$ Elements not present or not present in detectable concentrations.

Table 3. Continued.

\begin{tabular}{|c|c|c|c|c|c|c|c|}
\hline Sample No. & EV-140 & EV-141 & EV-142 & EV-143 & EV-144 & EV-145 & EV-146 \\
\hline Location & $\begin{array}{c}\text { (C-33-18)20bdd } \\
37^{\circ} 52^{\prime} 31^{\prime \prime} \\
113^{\circ} 49^{\prime} 16^{\prime \prime} \\
\end{array}$ & $\begin{array}{c}\text { (C-33-17) 20cbb } \\
37^{\circ} 55^{\prime} 30^{\prime \prime} \\
113^{\circ} i 7^{\prime} 02^{\prime \prime} \\
\end{array}$ & $\begin{array}{c}(\mathrm{C}-34-14) 31 \mathrm{cca} \\
37^{\circ} 47^{\prime} 51^{\prime \prime} \\
113^{\circ} 28^{\prime} 06^{\prime \prime} \\
\end{array}$ & $\begin{array}{c}\text { (C-34-13) 16bce } \\
37^{\circ} 50^{\prime} 22^{\prime \prime} \\
113^{\circ} 19^{\prime} 30^{\prime \prime} \\
\end{array}$ & $\begin{array}{c}(C-33-14) 6 d b a \\
37^{\circ} 57^{\prime} 51^{\prime \prime} \\
113^{\circ} 27^{\prime} 42^{\prime \prime} \\
\end{array}$ & $\begin{array}{c}(\mathrm{C}-35-15) 10 \mathrm{bac} \\
37^{\circ} 46^{\prime} 23^{\prime \prime} \\
113^{\circ} 31^{\prime} 17^{\prime \prime} \\
\end{array}$ & $\begin{array}{c}(\mathrm{C}-35-15) 3 \mathrm{dcc} \\
37^{\circ} 46^{\prime} 23^{\prime \prime} \\
113^{\circ} 31^{\prime 01} 1^{\prime \prime}\end{array}$ \\
\hline Temp. ${ }^{\circ} \mathrm{C}$ & 20 & 22 & 12 & 15 & 15 & 13 & 15 \\
\hline pH & 7.91 & 7.61 & 7.46 & 7.23 & 7.00 & 7.61 & 7.31 \\
\hline tds (mg/l) & 304 & 672 & 340 & 580 & 1350 & 372 & 2646 \\
\hline $\mathrm{HCO}_{3}(\mathrm{mg} / \mathrm{l})$ & 292 & 167 & 209 & 200 & 184 & 175 & 166 \\
\hline $\mathrm{Na}(\mathrm{mg} / \mathrm{l})$ & 25 & 54 & 44 & 37 & 106 & 21 & 208 \\
\hline K (mg/) & 7 & 8 & 6 & $\mathbf{u}$ & 6 & 3 & 11 \\
\hline $\mathrm{Ca}(\mathrm{mg} / \mathrm{l})$ & 41 & 96 & 29 & 64 & 210 & 50 & 356 \\
\hline $\mathrm{SiO}_{2}(\mathrm{mg} / \mathrm{l})$ & 58 & 46 & 52 & 27 & 38 & 41 & 46 \\
\hline $\mathrm{Mg}(\mathrm{mg} / 1)$ & 11 & 34 & 15 & 43 & 67 & 20 & 163 \\
\hline $\mathrm{Fe}(\mathrm{mg} / \mathrm{l})$ & 0.10 & 0.05 & 0.53 & 0.07 & 0.34 & $\mathbf{u}$ & $\mathbf{u}$ \\
\hline $\mathrm{Ti}(\mathrm{mg} / 1)$ & $\mathbf{u}$ & $\mathbf{u}$ & $\mathbf{u}$ & $\mathbf{u}$ & 0.2 & $\mathbf{u}$ & $\mathbf{u}$ \\
\hline $\mathrm{Sr}(\mathrm{mg} / \mathrm{l})$ & 0.30 & 0.84 & 0.59 & 0.90 & 1.87 & 0.56 & 5.14 \\
\hline W (mg/l) & $\mathbf{u}$ & $\mathbf{u}$ & $\mathbf{u}$ & $\mathrm{u}$ & $\mathbf{u}$ & $\mathbf{u}$ & $\mathbf{u}$ \\
\hline $\mathrm{Mn}(\mathrm{mg} / \mathrm{l})$ & $\mathbf{u}$ & $\mathbf{u}$ & $\mathbf{u}$ & $\mathrm{u}$ & $\mathbf{u}$ & u & $\mathrm{u}$ \\
\hline $\mathrm{Zn}(\mathrm{mg} / \mathrm{l})$ & 0.3 & 0.7 & 0.3 & $\mathbf{u}$ & 0.7 & $\mathrm{u}$ & 0.2 \\
\hline $\mathrm{Li}(\mathrm{mg} / \mathrm{l})$ & $\mathbf{u}$ & $\mathbf{u}$ & $\mathbf{u}$ & $\mathbf{u}$ & 0.06 & $\mathbf{u}$ & 0.21 \\
\hline B (mg/l) & $\mathbf{u}$ & 0.3 & 0.2 & $\mathbf{u}$ & 0.4 & 0.2 & 0.7 \\
\hline$F(\mathrm{mg} / \mathrm{l})$ & 0.5 & 0.7 & 0.6 & 0.4 & 1.2 & 0.5 & 0.6 \\
\hline $\mathrm{Cl}(\mathrm{mg} / \mathrm{l})$ & 37 & 46 & 25 & 33 & 493 & 34 & 528 \\
\hline $\mathrm{SO}^{4}(\mathrm{mg} / \mathrm{l})$ & 26 & 188 & 45 & 196 & 296 & 70 & 1003 \\
\hline
\end{tabular}

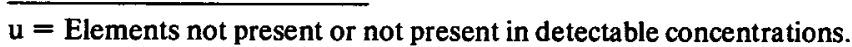


Table 3. Continued.

\begin{tabular}{|c|c|c|c|c|c|c|c|}
\hline Sample No. & EV-148 & EV-149 & EV-150 & EV-151 & EV-152 & EV-153 & EV-154 \\
\hline Location & $\begin{array}{c}(\mathrm{C}-30-13) 33 \mathrm{abb} \\
38^{\circ} 09^{\prime} 36^{\prime \prime} \\
113^{\circ} 18^{\prime} 45^{\prime \prime} \\
\end{array}$ & $\begin{array}{c}\mathrm{C}-30-13) 30 \mathrm{caa} \\
38^{\circ} 10^{\prime} 13^{\prime \prime} \\
113^{\circ} 19^{\prime} 32^{\prime \prime} \\
\end{array}$ & $\begin{array}{c}(C-33-16) 10 \mathrm{ccc} \\
37^{\circ} 56^{\prime} 25^{\prime \prime} \\
113^{\circ} 38^{\prime} 12^{\prime \prime} \\
\end{array}$ & $\begin{array}{c}\text { Thermo Hot } \\
\text { Springs } \\
\end{array}$ & $\begin{array}{c}\text { Thermo Hot } \\
\text { Springs } \\
\end{array}$ & $\begin{array}{c}\text { Thermo Hot } \\
\text { Springs }\end{array}$ & $\begin{array}{c}\text { Thermo Hot } \\
\text { Springs }\end{array}$ \\
\hline Temp. ${ }^{\circ} \mathrm{C}$ & 13 & 15 & 28 & 56 & 42 & 50 & 78 \\
\hline $\mathrm{pH}$ & 7.47 & 7.51 & 7.13 & 6.60 & 6.80 & 7.45 & 6.98 \\
\hline tds (mg/l) & 1042 & 686 & 1556 & 1524 & 1564 & 1518 & 1495 \\
\hline $\mathrm{HCO}_{3}(\mathrm{mg} / \mathrm{l})$ & 192 & 200 & 476 & 392 & 401 & 401 & 401 \\
\hline $\mathrm{Na}$ (mg/l) & 85 & 67 & 376 & 378 & 387 & 379 & 371 \\
\hline K (mg/l) & 10 & 5 & 24 & 51 & 52 & 51 & 50 \\
\hline $\mathrm{Ca}(\mathrm{mg} / \mathrm{l})$ & 106 & 96 & 145 & 77 & 78 & 85 & 69 \\
\hline $\mathrm{SiO}_{2}(\mathrm{mg} / \mathrm{l})$ & 41 & 11 & 44 & 87 & 87 & 89 & 84 \\
\hline $\mathrm{Mg}(\mathrm{mg} / \mathrm{l})$ & 83 & 38 & 14 & 10 & 10 & 10 & 10 \\
\hline $\mathrm{Fe}(\mathrm{mg} / \mathrm{l})$ & $\mathbf{u}$ & $\mathrm{u}$ & 1.64 & 0.03 & $\mathbf{u}$ & 0.04 & 0.04 \\
\hline $\mathrm{Ti}(\mathrm{mg} / \mathrm{l})$ & $\mathbf{u}$ & $\mathbf{u}$ & 0.2 & $\mathbf{u}$ & $\mathbf{u}$ & $\mathrm{u}$ & $\mathbf{u}$ \\
\hline $\mathrm{Sr}(\mathrm{mg} / 1)$ & 0.87 & 1.49 & 2.76 & 1.18 & 1.22 & 1.20 & 1.15 \\
\hline W (mg/l) & $\mathbf{u}$ & $\mathbf{u}$ & $\mathbf{u}$ & $\mathbf{u}$ & $\mathbf{u}$ & $\mathbf{u}$ & $\mathbf{u}$ \\
\hline $\mathrm{Mn}(\mathrm{mg} / \mathrm{l})$ & $\mathbf{u}$ & $\mathbf{u}$ & 0.7 & $\mathbf{u}$ & $\mathbf{u}$ & $\mathbf{u}$ & $\mathbf{u}$ \\
\hline $\mathrm{Zn}(\mathrm{mg} / \mathrm{l})$ & $\mathbf{u}$ & 0.1 & 0.8 & 0.2 & $\mathbf{u}$ & 0.3 & $\mathbf{u}$ \\
\hline $\mathrm{Li}(\mathrm{mg} / \mathrm{l})$ & 0.14 & $\mathbf{u}$ & 0.96 & 1.21 & 1.26 & 1.23 & 1.18 \\
\hline $\mathrm{B}(\mathrm{mg} / \mathrm{l})$ & 0.3 & $\mathrm{u}$ & 0.9 & 1.0 & 1.0 & 1.0 & 1.0 \\
\hline$F(\mathrm{mg} / \mathrm{l})$ & 1.2 & 0.9 & 4.0 & 6.5 & 6.5 & 5.6 & 6.0 \\
\hline $\mathrm{Cl}(\mathrm{mg} / \mathrm{l})$ & 289 & 132 & 366 & 222 & 222 & 220 & 222 \\
\hline $\mathrm{SO}^{4}(\mathrm{mg} / \mathrm{l})$ & 188 & 157 & 359 & 474 & 476 & 475 & 460 \\
\hline
\end{tabular}

$\mathrm{u}=$ Elements not present or not present in detectable concentrations.

\section{Total Dissolved Solids}

Mower (1982) reports that a sample from a particular well in the southern Escalante Valley area is a composite water sample because most wells are screened continuously from the water table downward. Commonly, total dissolved solids (TDS) concentrations are greatest at the water table and decrease with depth (Mower, 1982). Therefore, only very general observations can be presented with respect to TDS because the wells sampled vary with respect to screening depth below the water table.

TDS concentrations ranged from 276 to $5360 \mathrm{mg} / 1$ in the study area. Distribution of these values within the designated sampling areas is presented in Figure 10. Generally, TDS concentrations are less than 1000 $\mathrm{mg} / 1$ (the lower extent of USGS classification of slightly saline waters) with the exceptions of isolated wells, area III in Plate 7 and Thermo Hot Springs. The values greater than $1000 \mathrm{mg} / 1$ from the isolated wells could result from recycling of irrigation water with higher TDS concentrations (Mower, 1982). The consistently high values from all samples collected in area III are thought to preclude irrigation water recycling and could be the result of recharge from bedrock fault(s) or jointing. TDS will be discussed further in the following section entitled "Common Ion Analysis."

\section{Common Ion Analysis}

Common ion analyses, grouped by geographic area in the Escalante Valley, are presented in trilinear diagrams in Figures 11 through 18. A composite trilinear diagram of all samples is presented in Figure 19. Data plotted in Figure 19 indicate there are three general types of water present in the study area. Type I waters, which comprise the majority of samples collected, consist of calcium-sodium bicarbonatechloride-sulfate (Ca-Na $\mathrm{HCO}_{3}-\mathrm{Cl}-\mathrm{SO}_{4}$ ), calciumsodium chloride-sulfate-bicarbonate (Ca- $\mathrm{Na} \mathrm{Cl}$ $\mathrm{SO}_{4}-\mathrm{HCO}_{3}$ ), and calcium-sodium chloride-sulfate (Ca-Na Cl-SO4) character. These waters are found throughout the valley and are not concentrated in one geographic location. The $\mathrm{Ca}-\mathrm{Na} \mathrm{HCO}_{3}-\mathrm{Cl}_{-} \mathrm{SO}_{4}$ and $\mathrm{Ca}-\mathrm{Na} \mathrm{Cl}-\mathrm{SO}_{4}-\mathrm{HCO}_{3}$ waters are basic and dilute to slightly saline, with TDS values ranging from 268 to $2194 \mathrm{mg} / 1$. Samples EV-144, EV-135, and EV-115 are $\mathrm{Ca}-\mathrm{Na} \mathrm{Cl}-\mathrm{SO}_{4}$ in character and are slightly to moderately saline with TDS values of 2330,2480 , and $5360 \mathrm{mg} / 1$ respectively. EV-115 is anomalous in that the TDS concentration is more than twice that of any other sample.

Type II waters consist of samples EV-117, EV-118, EV-119, and EV-150, are sodium-calcium chloridesulfate-bicarbonate $\left(\mathrm{Na}-\mathrm{Ca} \mathrm{Cl}-\mathrm{SO}_{4}-\mathrm{HCO}_{3}\right)$ in character and are located in area III on Plate 7. These waters 


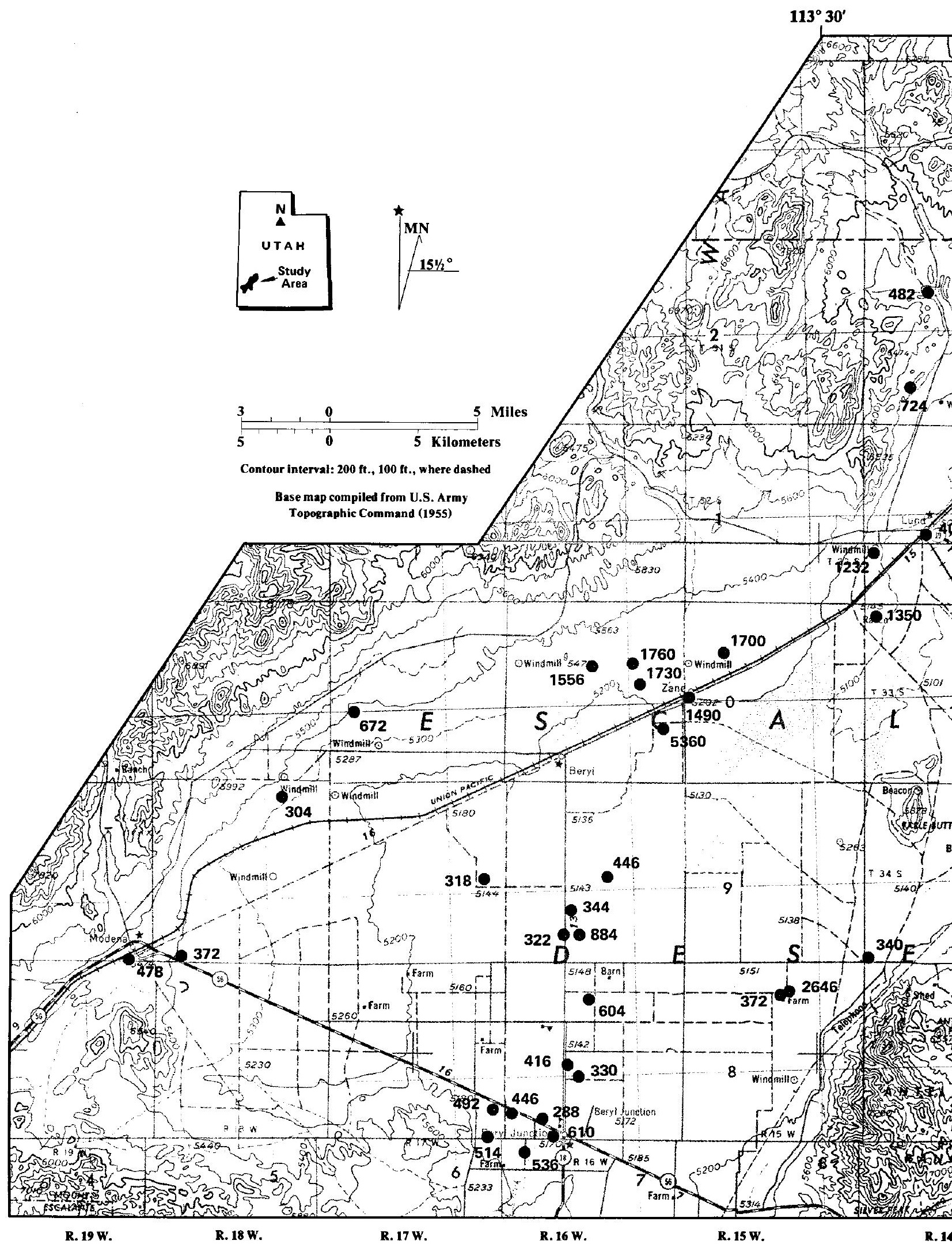


R. 13 w.

R.12 w.

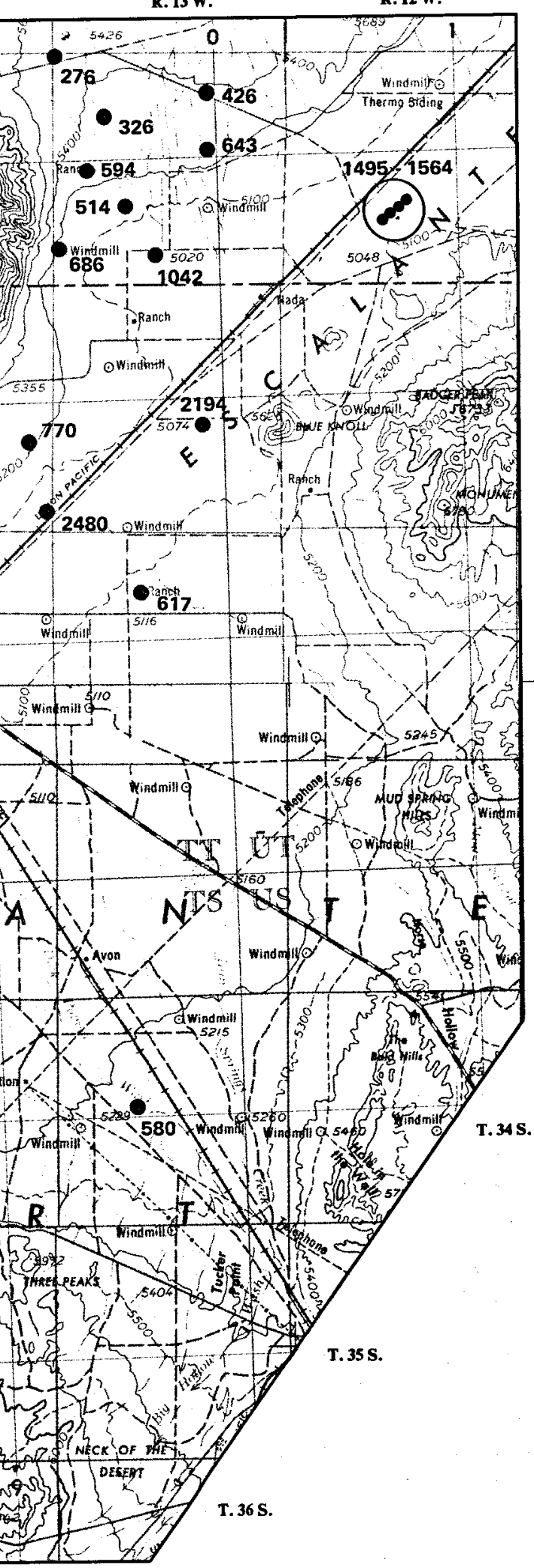

Figure 10.

Total dissolved solids (TDS) measured in the Escalante Valley, Iron and Beaver Counties, Utah.

T. 31 s.

\section{EXPLANATION}

- Location: Values in milligrams per liter

T. $32 \mathrm{~S}$.

$3^{\circ}$

(2) Thermo Hot Springs area 


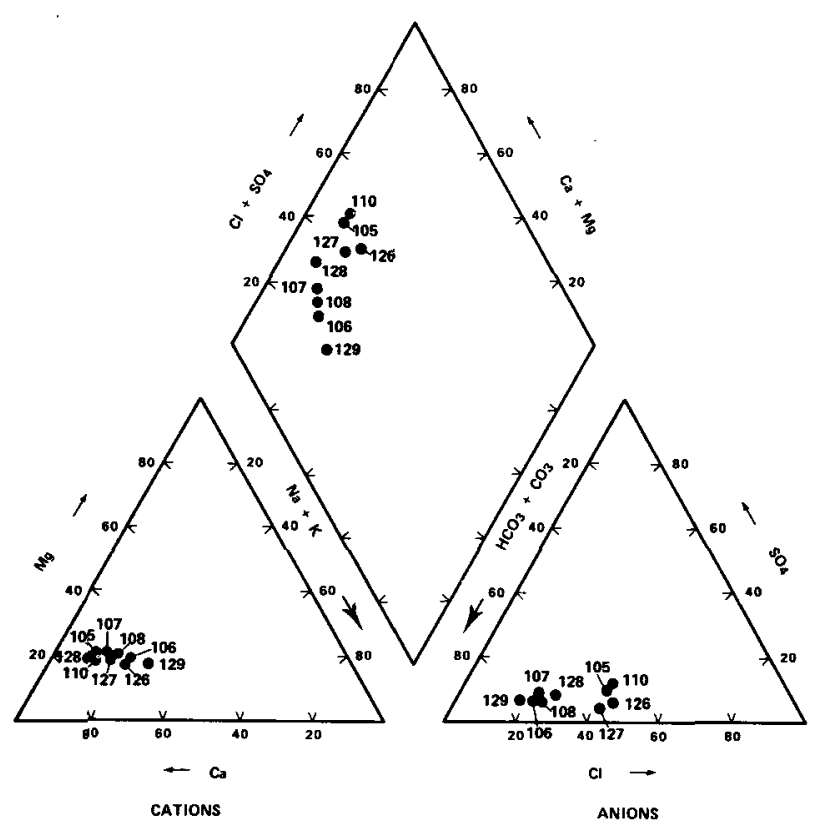

Figure 11. Piper diagram of common ions in samples collected from Area VII (Figure 9) in the Escalante Valley, Utah.

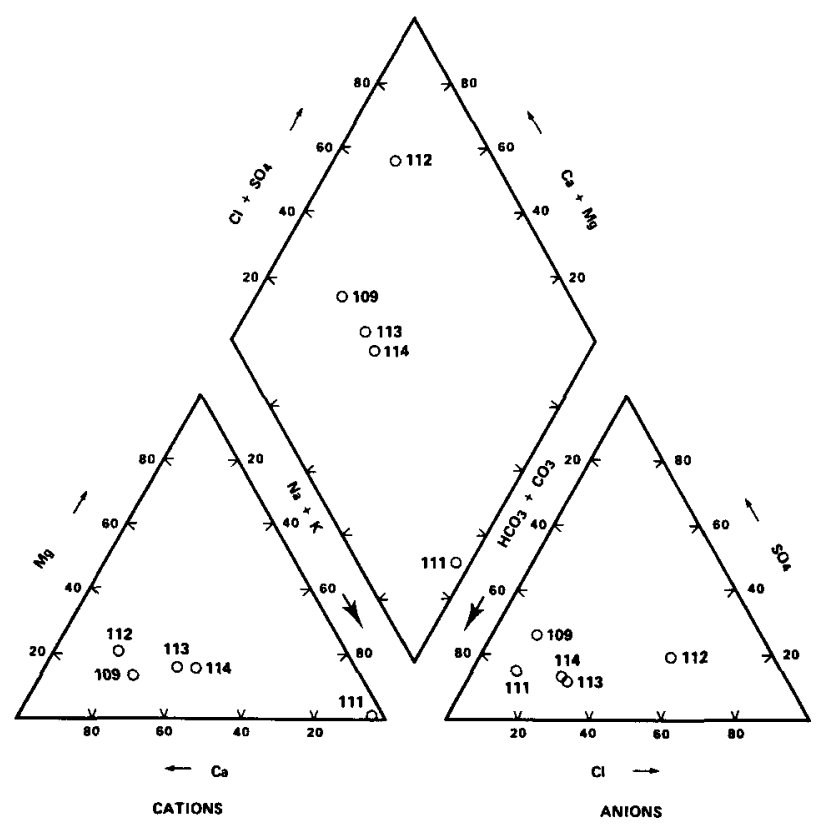

Figure 12. Piper diagram of common ions in samples collected from Area V (Figure 9) in the Escalante Valley, Utah.

are slightly basic and slightly saline with TDS concentrations ranging from 1556 to $1760 \mathrm{mg} / \mathrm{l}$. All four samples are enriched in $\mathrm{Na}$ and $\mathrm{K}$ with respect to other cations. EV-117 and 118 are enriched with respect to other anions while EV-119 and EV-150 (the warmest well water measured) are enriched with

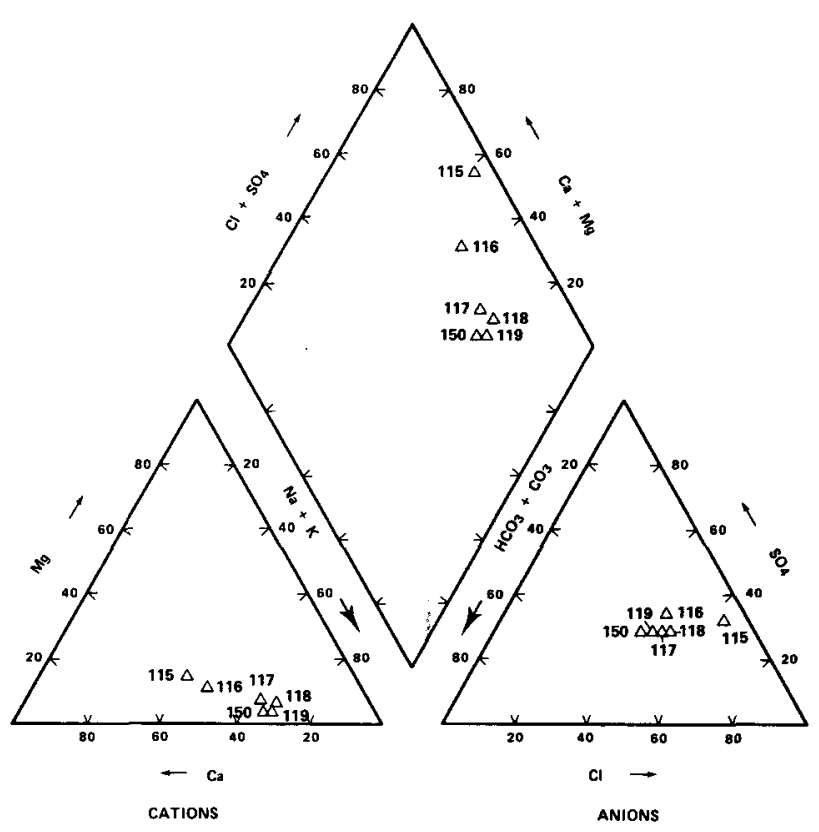

Figure 13. Piper diagram of common ions in samples collected from Area III (Figure 9) in the Escalante Valley, Utah.

$\mathrm{SO}_{4}$. Type III waters constitute four samples (EV-151, EV-152, EV-153, and EV-154) collected at Thermo Hot Springs (Figure 9). Thermo water is sodium-calcium chloride-sulfate-bicarbonate $(\mathrm{Na}-\mathrm{Ca}$ $\mathrm{Cl}-\mathrm{SO}_{4}-\mathrm{HCO}_{3}$ ) in character and enriched in $\mathrm{Na}, \mathrm{K}$, and $\mathrm{SO}_{4}$ with respect to other cations and anions present. TDS concentrations ranged from 1495 to $1564 \mathrm{mg} / \mathrm{l}$ indicating the water is slightly saline while $\mathrm{pH}$ values ranged from slightly basic to slightly acidic.

In addition to three major types, two other wells (EV-111 and EV-121) provided water samples with significantly different chemistries (Figures 11 and 13). EV-121 is sodium-calcium bicarbonatechloride-sulfate $\left(\mathrm{Na}-\mathrm{Ca} \mathrm{HCO}_{3}-\mathrm{Cl}-\mathrm{SO}_{4}\right)$ in character, basic, with a TDS concentration of $426 \mathrm{mg} / 1$. This water is enriched in $\mathrm{Na}$ and $\mathrm{HCO}_{3}$ with respect to other cations and anions present. EV-111 was sampled from a geothermal test well $8072 \mathrm{ft}(2461$ $\mathrm{m})$ in depth. The $60^{\circ} \mathrm{C}\left(140^{\circ} \mathrm{F}\right)$ temperature measured is accountable by the normal geothermal gradient for this part of the Basin and Range province. The chemical character of the water is sodium bicarbonate-chloride-sulfate $\left(\mathrm{Na} \quad \mathrm{HCO}_{3}-\mathrm{Cl}-\mathrm{SO}_{4}\right)$, basic, with a TDS concentration of $446 \mathrm{mg} / 1$. The water is highly enriched in $\mathrm{Na}$ and $\mathrm{HCO}_{3}$ with respect to other cations and anions and could be indicative of deep basin ground water circulation and not be considered as having geothermal resource potential. 


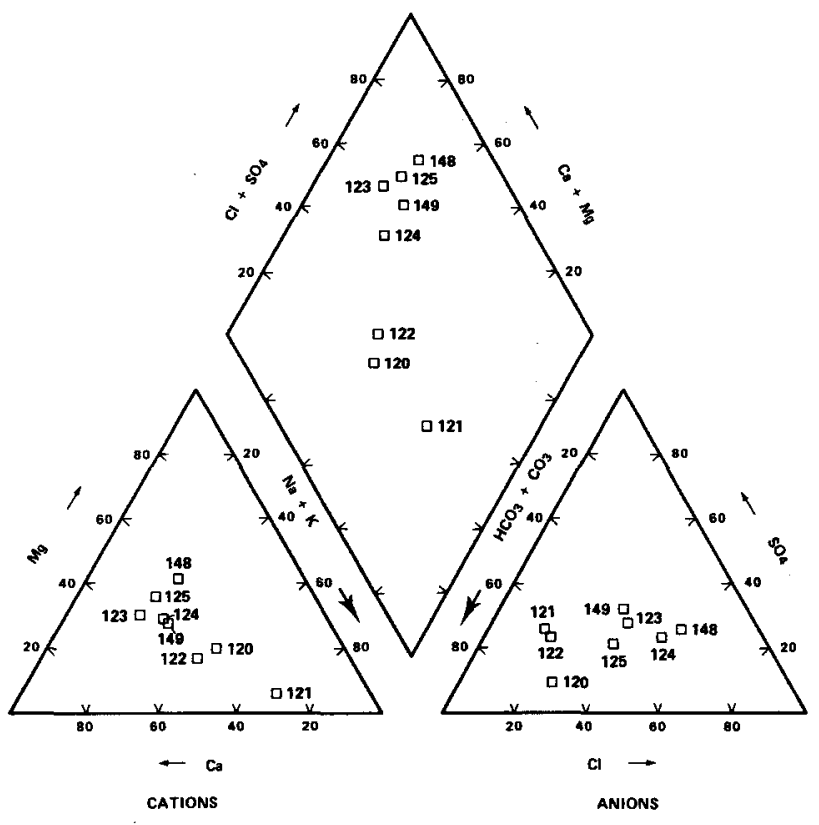

Figure 14. Piper diagram of common ions in samples collected from Area I (Figure 9) in the Escalante Valley, Utah.

\section{Silica $\left(\mathrm{SiO}_{2}\right)$}

Silica concentrations ranged from 11 to $58 \mathrm{mg} / 1$ for wells sampled in the Escalante Valley while values for Thermo Hot Springs were between 84 and 89 $\mathrm{mg} / \mathrm{l}$. Water with lower concentrations (less than 40 $\mathrm{mg} / \mathrm{l})$ were principally to the northeast in areas I and II in Figure 9, west and southwest, respectively, from Thermo Hot Springs. With the exception of Thermo Hot Springs, no obvious anomalous silica values were noted in the study area.

\section{Other Elements}

Elements present in sufficient anounts to be detected by the University of Utah Research Institute/ Earth Science Laboratory using an ARL Inductively Coupled Plasma Quantometer (ICPQ) or other methods consist of: iron $(\mathrm{Fe})$, strontium $(\mathrm{Sr})$, zinc $(\mathrm{Zn})$, lithium (Li), boron (B), and fluoride (F) (see Table 2 for the Limits of Quantitative Determination (LQD) for solution analysis by the ICPQ). It should be noted; however, that not all samples contained sufficient amounts of $\mathrm{Fe}, \mathrm{Li}, \mathrm{Sr}, \mathrm{B}, \mathrm{Zn}, \mathrm{W}, \mathrm{Ti}$, and $\mathrm{Mn}$ to reach detection limits. Of the aforementioned elements, $\mathrm{Li}$ and $\mathrm{B}$ are present in sufficient concentrations in 5 samples from area III (area with the highest well water temperatures measured in the study area) to indicate a possible geothermal anomaly (Figure 9).

Lithium ( $\mathrm{Li}$ ) values for wells sampled in areas I, II, and IV through VIII on Figure 9 ranged from undec-

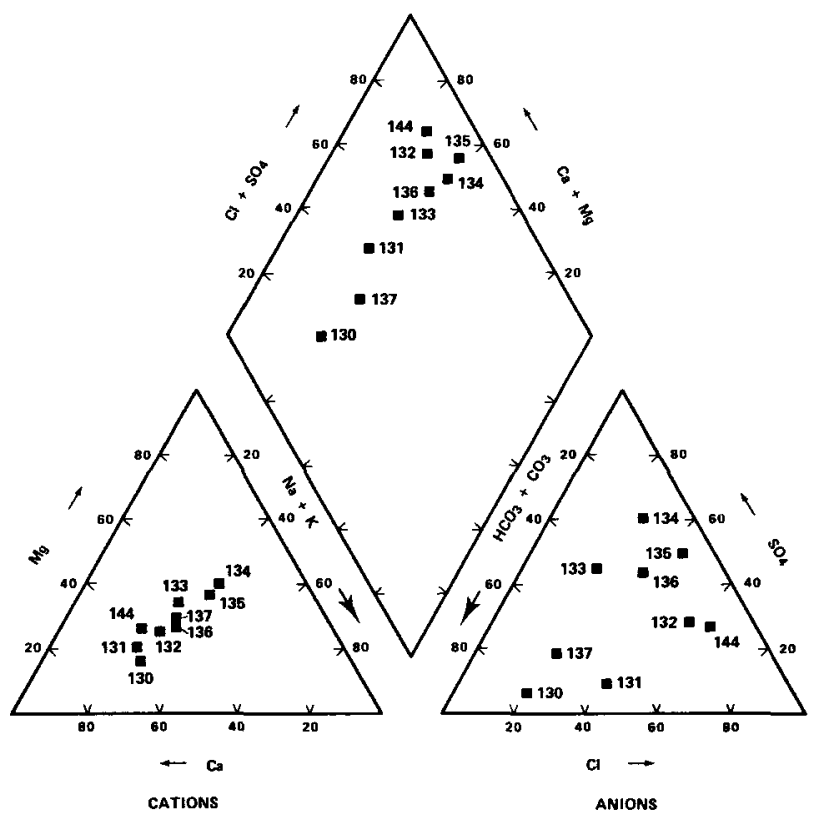

Figure 15. Piper diagram of common ions in samples collected from Area II (Figure 9) in the Escalante Valley, Utah.

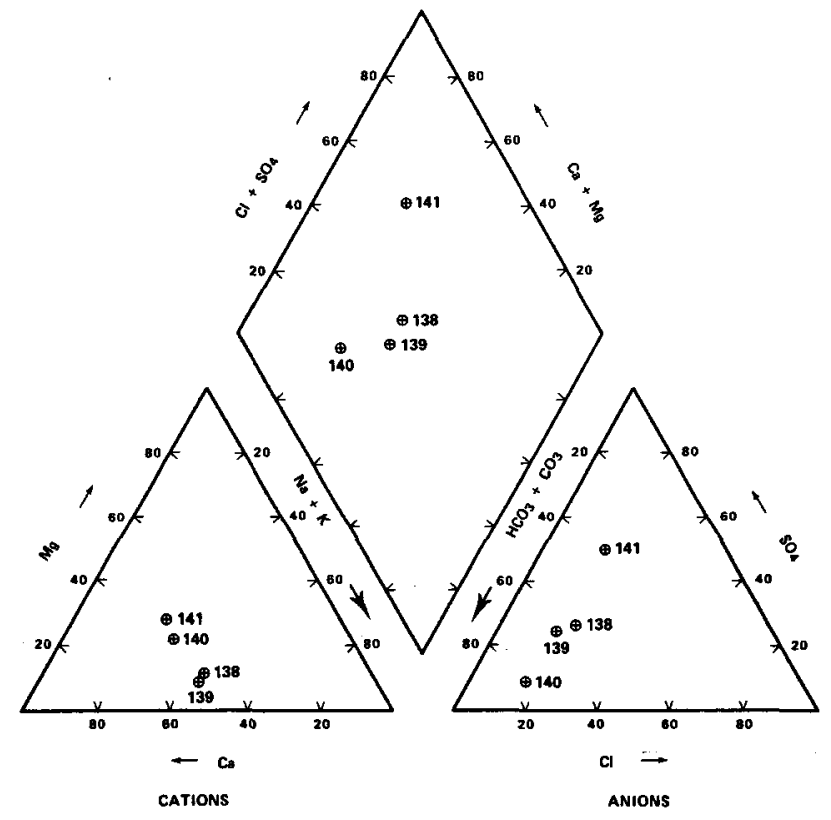

Figure 16. Piper diagram of common ions in samples collected from Area IV (Figure 9) in the Escalante Valley, Utah.

tectable to $0.21 \mathrm{mg} / 1$. Except for sample EV-116 $(\mathrm{Li}=0.26 \mathrm{mg} / \mathrm{l}), \mathrm{Li}$ concentrations for samples in area III ranged from 0.96 to $1.07 \mathrm{mg} / 1$, a significant increase relative to values measured in other water well samples. Li concentrations for Thermo Hot Springs were higher, ranging from 1.18 to $1.26 \mathrm{mg} / 1$, but were still similar to those measured in area III. Boron (B) values in all water wells sampled ranged from un- 


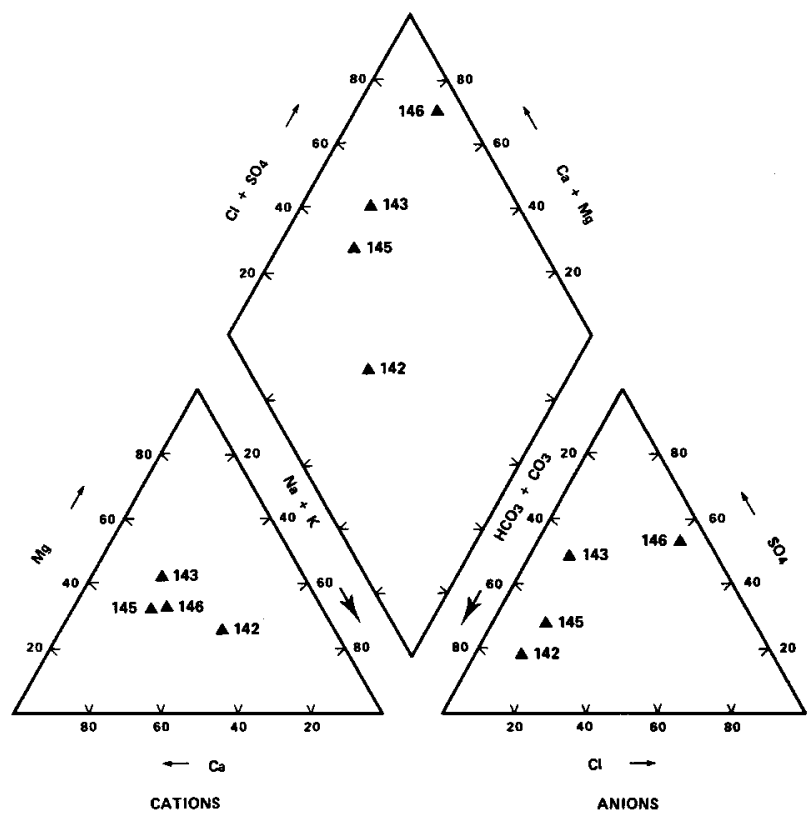

Figure 17. Piper diagram of common ions in samples collected from Area VI (Figure 9) in the Escalante Valley, Utah.

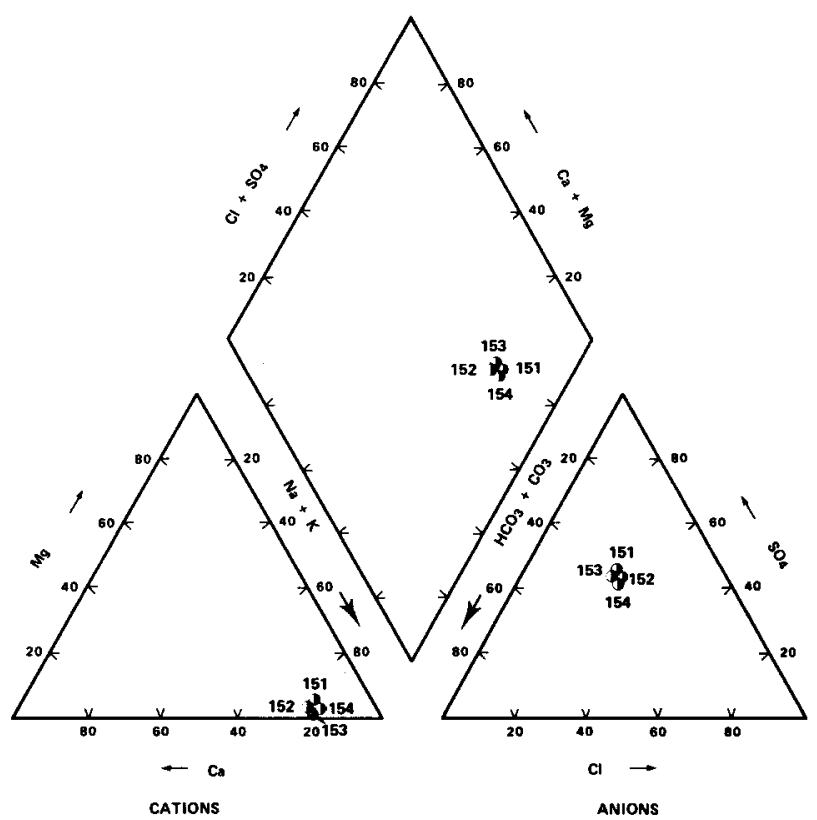

Figure 18. Piper diagram of common ions in samples collected from Thermo Hot Springs (Figure 9) in the Escalante Valley, Utah.

detectable to $1.2 \mathrm{mg} / \mathrm{l}$. The four samples collected at Thermo Hot Springs all had concentrations of 1.0 $\mathrm{mg} / \mathrm{l}$ while the deep geothermal exploration well sampled contained $5.3 \mathrm{mg} / 1$ of $B$. Of all water wells sampled, area III contained the greatest concentrations of B; values for all samples except EV-116 (0.6

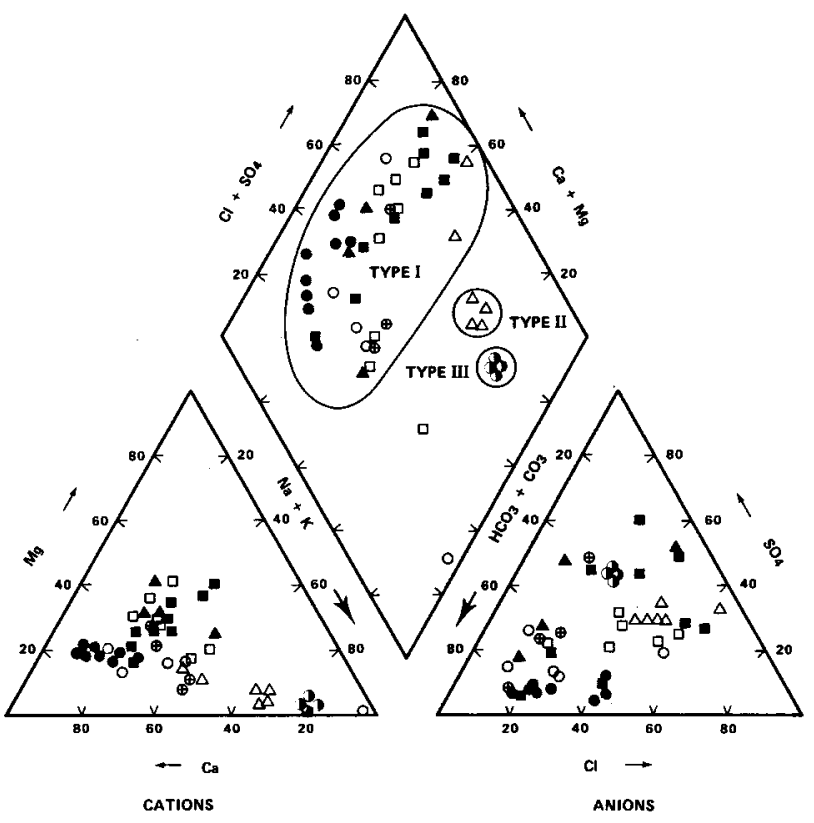

Figure 19. Piper diagram of common ions in all samples collected in the Escalante Valley, Utah.

$\mathrm{mg} / \mathrm{l})$ ranged from 0.9 to $1.2 \mathrm{mg} / \mathrm{l}$, which are similar to the values measured at Thermo Hot Springs. The $\mathrm{B} / \mathrm{Cl}$ ratios (conservative element ratio) for samples $\mathrm{EV}-118, \mathrm{EV}-119$, and EV-150 in area III were very similar relative to the ratios for other samples in the area. This indicates that either no mixing is occurring between warm and cold waters in this area, or that mixing has occurred prior to interception by these wells.

Figure 20, a plot of $\mathrm{Li}$ versus B values for all samples collected in the Escalante Valley, denotes that samples EV-115, 117, 118, 119, and 150 in area III are similar to Thermo Hot Springs samples and quite dissimilar to EV-116, as well as to all other samples collected in the valley. This indicates that part of area III is chemically anomalous to the other areas of the valley sampled and because of the chemical similarity with Thermo Hot Springs, suggests a geothermal anomaly.

\section{Geothermometry}

Chemical geothermometers were calculated for all water samples collected in the Escalante Valley. Quartz (conductive), chalcedony and sodiumpotassium-calcium (Na-K-Ca) Mg corrected geothermometers were used. Equations used and results obtained are presented in Table 4 . The reliability of geothermometers depends on five assumptions which are applicable to both the silica and $\mathrm{Na}-\mathrm{K}-\mathrm{Ca}$ techniques (Fournier and others, 1974). 


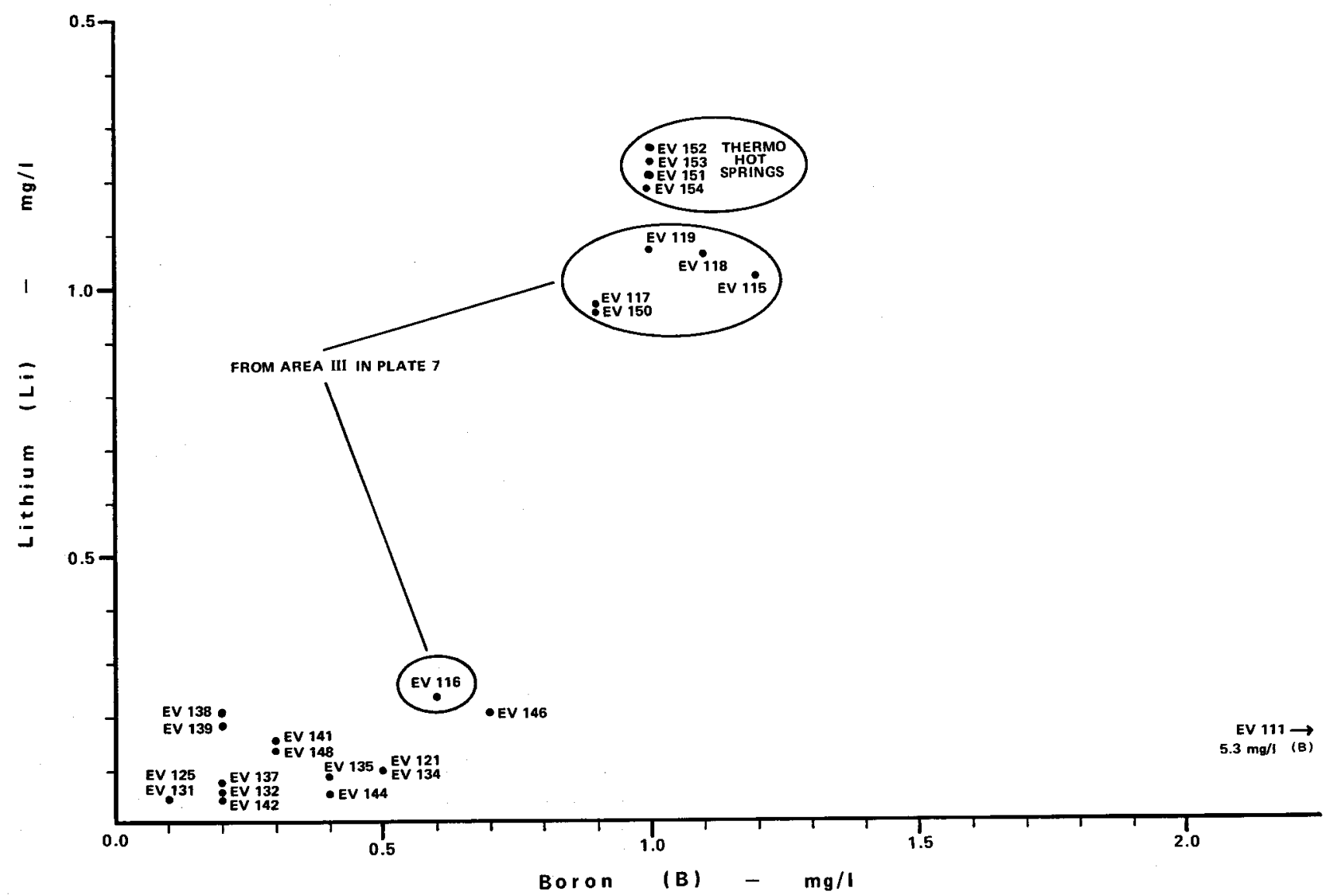

Figure 20. Plot of Lithium ( $\mathrm{Li}$ ) versus Boron (B) values for only those samples where both elements were present in detectable limits in the Escalante Valley, Utah.

These assumptions are:

1. Temperature-dependent reactions occur at depth;

2. all constituents involved in the temperaturedependent reactions are sufficiently abundant;

3. water-rock chemical equilibrations occur at the reservoir temperature;

4. little or no equilibration or change in composition occurs at lower temperatures as the water flows from the reservoir to the surface;

5. the hot water coming from deep in the system does not mix with cooler, shallow ground water.

Lack of proven low-to-moderate temperature geothermometer results, prompted only qualitative use of the results of this technique.

$\mathrm{Na}-\mathrm{K}-\mathrm{Ca}$ temperatures ( $\mathrm{Mg}$ corrected) for all water well samples, with the exceptions of EV-118, EV-119, and EV-150 in area III on Figure 9, as well as EV-111 in area V, ranged from 28 to $68^{\circ} \mathrm{C}$ (82 to $154^{\circ} \mathrm{F}$ ) (Table 4). Computed temperatures for EV-111 (the deep geothermal exploration well),
EV-118, 119, and 150 were $103,120,100$, and $115^{\circ} \mathrm{C}$ $\left(217,248,212\right.$, and $\left.239^{\circ} \mathrm{F}\right)$, respectively. Temperatures for Thermo Hot Springs ranged from 120 to $127^{\circ} \mathrm{C}$ ( 248 to $261^{\circ} \mathrm{F}$ ). The occurrence of warm springs with different temperatures and similar chloride content suggests conductive cooling is occurring. Thermo Hot Springs has $\mathrm{Cl}$ values ranging from 220 to $222 \mathrm{mg} / 1$ which would suggests conductive cooling is occurring in this geothermal system. Also, $\mathrm{B} / \mathrm{Cl}$ ratios are similar and therefore indicative of a nonmixing environment. Therefore, if re-equilibration has not occurred subsequent to the warm water leaving the reservoir, the $\mathrm{Na}-\mathrm{K}-\mathrm{Ca}$ temperatures calculated for Thermo Hot Springs should be relatively accurate. Since samples EV-118, 119, and 150 were collected from water wells that are screened at sand and gravel layers in the principal aquifer within the valley, it is highly conceivable that thermal water has mixed with cold water. $\mathrm{B} / \mathrm{Cl}$ ratios indicate these samples are very similar and therefore suggest no mixing has occurred. Therefore, it is thought mixing has occurred previously, and the mixed water has moved 
Table 4. Chemical geothermometers with magnesium correction where applicable and surface temperatures for fluids in $\left({ }^{\circ} \mathrm{C}\right)$ from the Escalante Valley, Utah.

\begin{tabular}{|c|c|c|c|c|}
\hline Sample No. & Qtz (Cond) & Chalcedony & $\mathrm{Na}-\mathrm{K}-\mathrm{Ca}$ & Meas. Temp. \\
\hline EV-105 & 96 & 66 & 37 & 14 \\
\hline EV-106 & 95 & 64 & 40 & 16 \\
\hline EV-107 & 93 & 62 & 35 & 14 \\
\hline EV-108 & 93 & 62 & 32 & 14 \\
\hline EV-109 & 105 & 76 & 52 & 17 \\
\hline EV-110 & 93 & 62 & 33 & 12 \\
\hline EV-111 & 105 & 76 & 115 & 60 \\
\hline EV-112 & 102 & 72 & 46 & 19 \\
\hline EV-113 & 107 & 78 & 57 & 14 \\
\hline EV-114 & 106 & 77 & 62 & 14 \\
\hline EV-115 & 102 & 72 & 68 & 15 \\
\hline EV-116 & 97 & 67 & 66 & 16 \\
\hline EV-117 & 94 & 63 & 39 & 17 \\
\hline $\mathrm{EV}-118$ & 101 & 71 & 103 & 27 \\
\hline EV-119 & 104 & 74 & 120 & 20 \\
\hline EV-120 & 74 & 42 & $\mathrm{~K}$ not detected & 18 \\
\hline $\mathrm{EV}-121$ & 106 & 77 & $\mathrm{~K}$ not detected & 16 \\
\hline $\mathrm{EV}-122$ & 86 & 55 & K not detected & 18 \\
\hline EV-123 & 69 & 37 & 26 & 15 \\
\hline EV-124 & 72 & 40 & 39 & 15 \\
\hline EV-125 & 86 & 55 & 38 & 16 \\
\hline EV-126 & 93 & 62 & 37 & 14 \\
\hline EV-127 & 100 & 70 & 41 & 14 \\
\hline EV-128 & 86 & 55 & 30 & 14 \\
\hline EV-129 & 92 & 61 & 46 & 16 \\
\hline EV-130 & 94 & 63 & $\mathrm{~K}$ not detected & 20 \\
\hline EV-131 & 83 & 52 & $\mathrm{~K}$ not detected & 20 \\
\hline EV -132 & 82 & 51 & 41 & 18 \\
\hline EV-133 & 77 & 45 & 46 & 14 \\
\hline EV-134 & 93 & 62 & 59 & 13 \\
\hline EV-135 & 86 & 55 & 59 & 14 \\
\hline EV -136 & 81 & 49 & 49 & 17 \\
\hline EV-137 & 103 & 73 & 60 & 19 \\
\hline EV-138 & 88 & 57 & 49 & 21 \\
\hline EV-139 & 94 & 63 & 58 & 16 \\
\hline EV-140 & 109 & 79 & 58 & 20 \\
\hline EV-141 & 98 & 68 & 52 & 22 \\
\hline EV-142 & 104 & 74 & 65 & 12 \\
\hline EV-143 & 75 & 44 & $\mathrm{~K}$ not detected & 15 \\
\hline EV-144 & 90 & 59 & 38 & 15 \\
\hline EV-145 & 93 & 62 & 30 & 13 \\
\hline EV-146 & 98 & 68 & 92 & 15 \\
\hline EV-148 & 93 & 62 & 61 & 13 \\
\hline EV-149 & 42 & 10 & 42 & 15 \\
\hline EV-150 & 96 & 66 & 100 & 28 \\
\hline EV-151 & 130 & 102 & 123 & 56 \\
\hline EV-152 & 130 & 102 & 124 & 42 \\
\hline EV-153 & 131 & 103 & 124 & 50 \\
\hline EV-154 & 128 & 100 & 117 & 78 \\
\hline
\end{tabular}

Equations for geothermometers used to compute subsurface temperatures

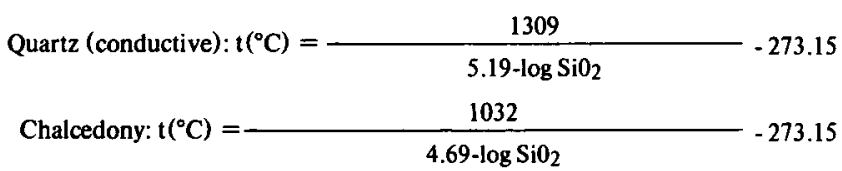

Sources: Fournier (1981); Fournier and Potter (1979).

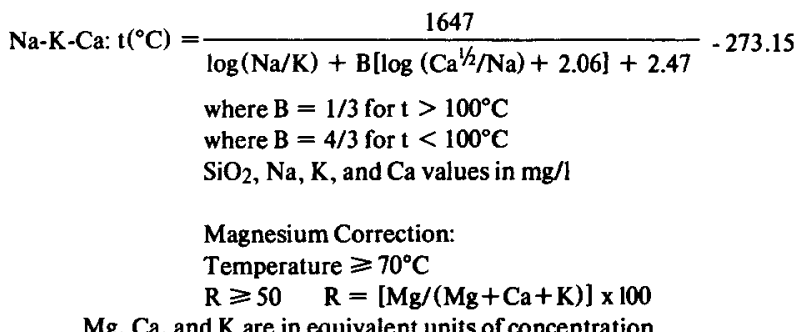


down gradient through the aquifer and subsequently been intercepted by the wells. Mixing of warm and cold water decreases the warm water temperature, which commonly causes $\mathrm{HCO}_{3}$ and $\mathrm{SO}_{4}$ to increase, as well as $\mathrm{K}$ to decrease relative to $\mathrm{Na}$ and $\mathrm{Ca}$ to increase relative to $\mathrm{Na}$ unless $\mathrm{CaCO}_{3}$ precipitates (Fournier, 1981). $\mathrm{HCO}_{3}$ and $\mathrm{SO}_{4}$ values of these three samples are significantly higher than concentrations in sample EV-141 which is in a similar environment, also indicating mixing has occurred. If, in fact, $\mathrm{K}$ has decreased relative to $\mathrm{Na}$, and $\mathrm{Ca}$ has increased relative to $\mathrm{Na}$, then the $\mathrm{Na}-\mathrm{K}-\mathrm{Ca}$ temperature calculated for these samples are, in fact, low.

Fournier (1977) suggests that if the Na-K-Ca geothermometer indicates a temperature of less than $100^{\circ} \mathrm{C}\left(212^{\circ} \mathrm{F}\right)$, the silica content of the water is a function of chalcedony solubility. For temperatures greater than $100^{\circ} \mathrm{C}\left(212^{\circ} \mathrm{F}\right)$, the silica temperature should be calculated assuming the silica content is a function of quartz solubility. In Iceland, Arnorsson (1975) found that when undissociated silica is less than $60 \mathrm{mg} / \mathrm{l}$, the silica temperature refers to equilibrium with chalcedony and between 60 and $250 \mathrm{mg} / 1$, it has not been determined whether chalcedony or quartz governs the amount of silica in the system. Due to the lack of consensus regarding which form of silica governs concentrations from temperatures between 100 and $180^{\circ} \mathrm{C}\left(212\right.$ and $\left.356^{\circ} \mathrm{F}\right)$, both chalcedony and quartz temperatures are given in Table 4.

Chalcedony temperatures range from 10 to $79^{\circ} \mathrm{C}$ (50 to $174^{\circ} \mathrm{F}$ ) for samples with Na-K-Ca temperatures less than $100^{\circ} \mathrm{C}\left(212^{\circ} \mathrm{F}\right)$. Quartz (conductive) temperatures for the remainder of the samples, which include EV-111 (deep geothermal exploration well), EV-118, EV-119, and EV-150 (Area III on Figure 9), and EV-151 through EV-154 (Thermo Hot Springs), range from 96 to $131^{\circ} \mathrm{C}\left(205\right.$ to $\left.268^{\circ} \mathrm{F}\right)$. Thermo Hot Springs values are quite similar to the derived $\mathrm{Na}-\mathrm{K}$-Ca temperatures which are considered to be relatively similar to temperatures expected at depth in the reservoir. Quartz (conductive) temperatures for samples EV-118, EV-119, and EV-150 in area III on Figure 9 were 101,104 , and $96^{\circ} \mathrm{C}(214$, 219 , and $\left.205^{\circ} \mathrm{F}\right)$, respectively. These temperatures (with the exception of EV-119) are very similar to those calculated with the Na-K-Ca geothermometer.

Attempts were made to apply the mixing model of Truesdell and Fournier (1977) to samples EV-118, EV-119, and EV-150. These attempts proved futile in all but one case (EV-118) due to the silica values being too low and/or the temperatures being too low for the model to be applicable. The results of model- ing sample EV-118 indicated a reservoir temperature of $128^{\circ} \mathrm{C}\left(262^{\circ} \mathrm{F}\right)$ could be expected. This temperature seems reasonable because the Na-K-Ca temperatures are considered to be low due to mixing, and this temperature is comparable to those expected at depth at Thermo Hot Springs.

\section{TEMPERATURE-DEPTH MEASUREMENTS}

Temperature-depth measurements, and the subsequent temperature gradients derived thereof, are useful in exploration for geothermal resources since they can allow for detection of thermal anomalies (Laughlin, 1982). Temperature gradients are affected by heat flow and thermal conductivity. Heat flow is the conductive transfer of heat from the earth's interior and therefore the surface expression of geothermal conditions at depth. For a given heat flow, the temperature gradient is inversely proportional to the thermal conductivity of the material through which the heat is being transmitted by conduction (Kappelmeyer and Haenel, 1974). At shallow depths, temperature gradients are affected by surface conditions such as temperature and precipitation. These effects are eliminated below $98 \mathrm{ft}(30 \mathrm{~m})$ in depth (Kappelmeyer and Haenel, 1974). Topography and in some exceptional cases sedimentation and denudation also have an affect on temperature gradients (Kappelmeyer and Haenel, 1974). Also, temperature measurements are strongly influenced by the movement of ground water (sometimes to depths of hundreds of meters) and it should always be recognized that temperature gradients are meaningful only for conductive heat transfer and that vertical, as well as horizontal, convection can upset the extrapolation of temperature information (Laughlin, 1982; Lumb, 1981).

Temperature-depth measurements in the Escalante Valley were completed in 22 "holes of opportunity" (Figure 21). Temperature-depth profiles of these measurements are presented in Figures 22 through 29. Locations by latitude and longitude, elevation, interval of gradient calculation, and calculated gradient are presented in Table 5. These "holes of opportunity" are primarily shallow abandoned water wells but include PVC cased holes from geotechnical investigations for the MX project and uncased mineral exploration holes.

Temperatures in holes were measured with a thermistor probe connected by a four wire configuration to a digital ohmmeter. A Fenwal K212E thermistor probe with a nominal resistance of $10,000 \mathrm{ohms}$ at $20^{\circ} \mathrm{C}\left(68^{\circ} \mathrm{F}\right)$, power dissipation of $50 \mathrm{~m} \mathrm{WK}^{-1}$ in still water, and a response time of 5 seconds was used. 


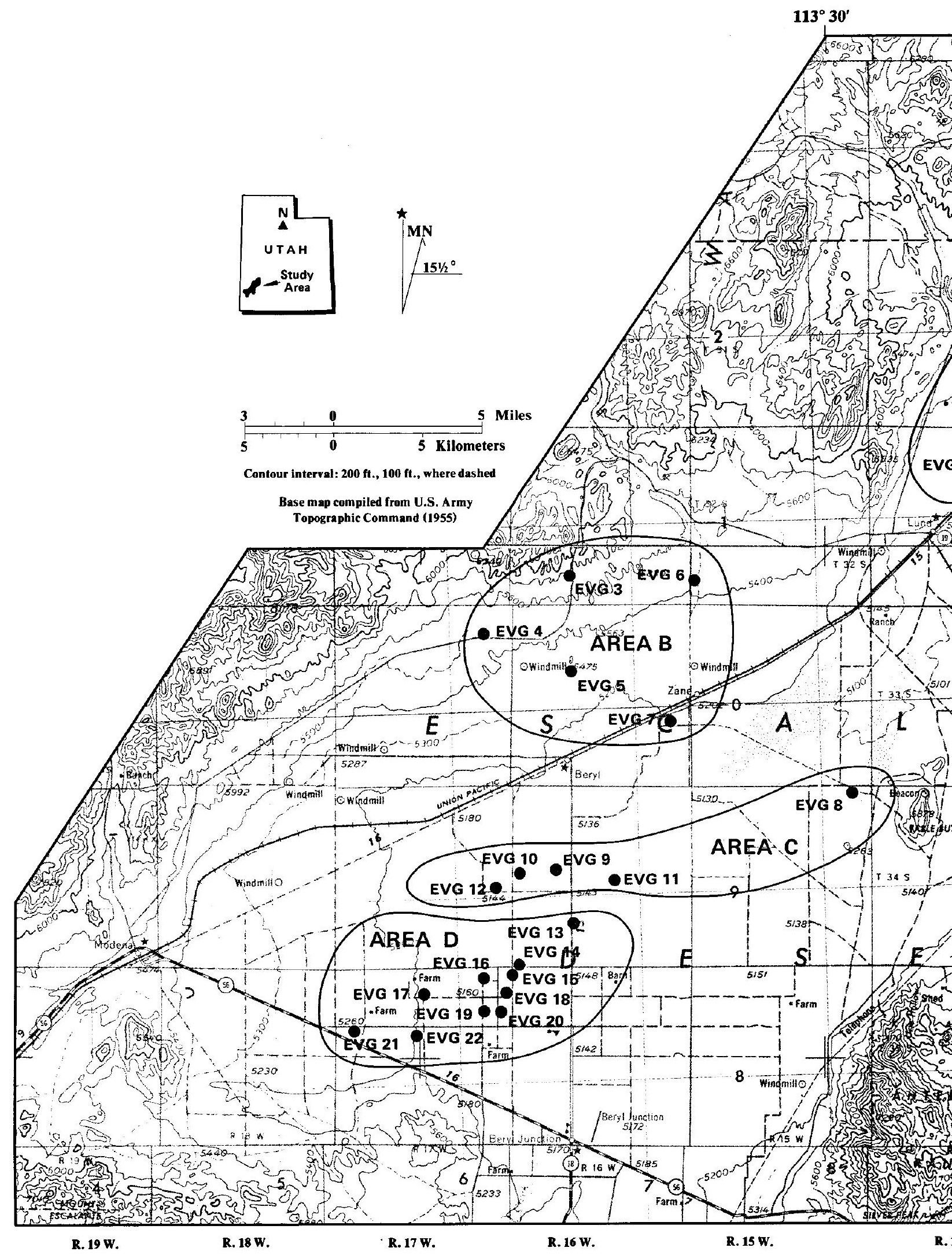




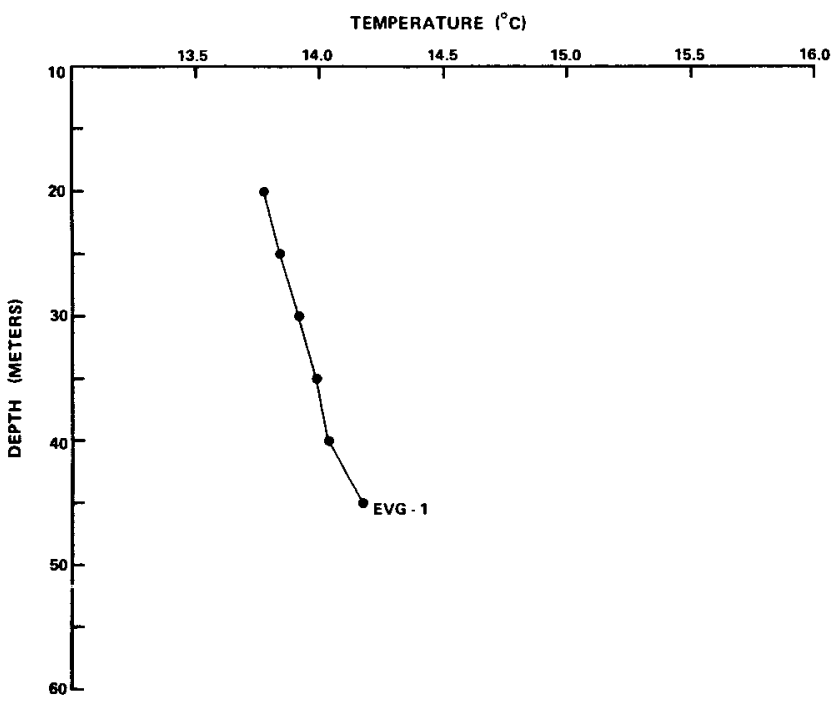

Figure 22. Temperature-depth profile of a "hole of opportunity" logged in Area A (Figure 21) in the Escalante Valley, Utah.

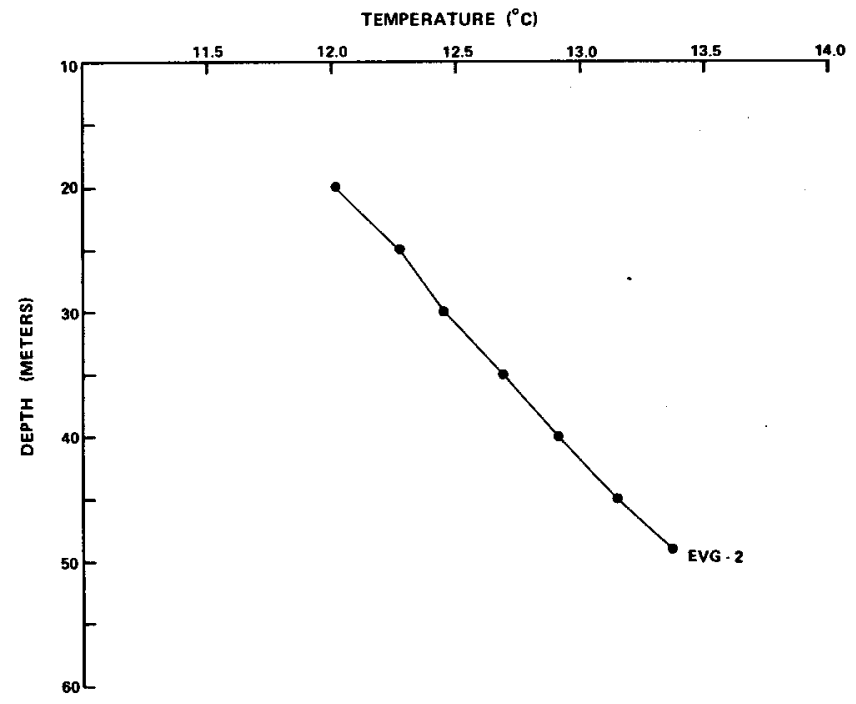

Figure 23. Temperature-depth profile of a "hole of opportunity" logged in Area A (Figure 21) in the Escalante Valley, Utah.

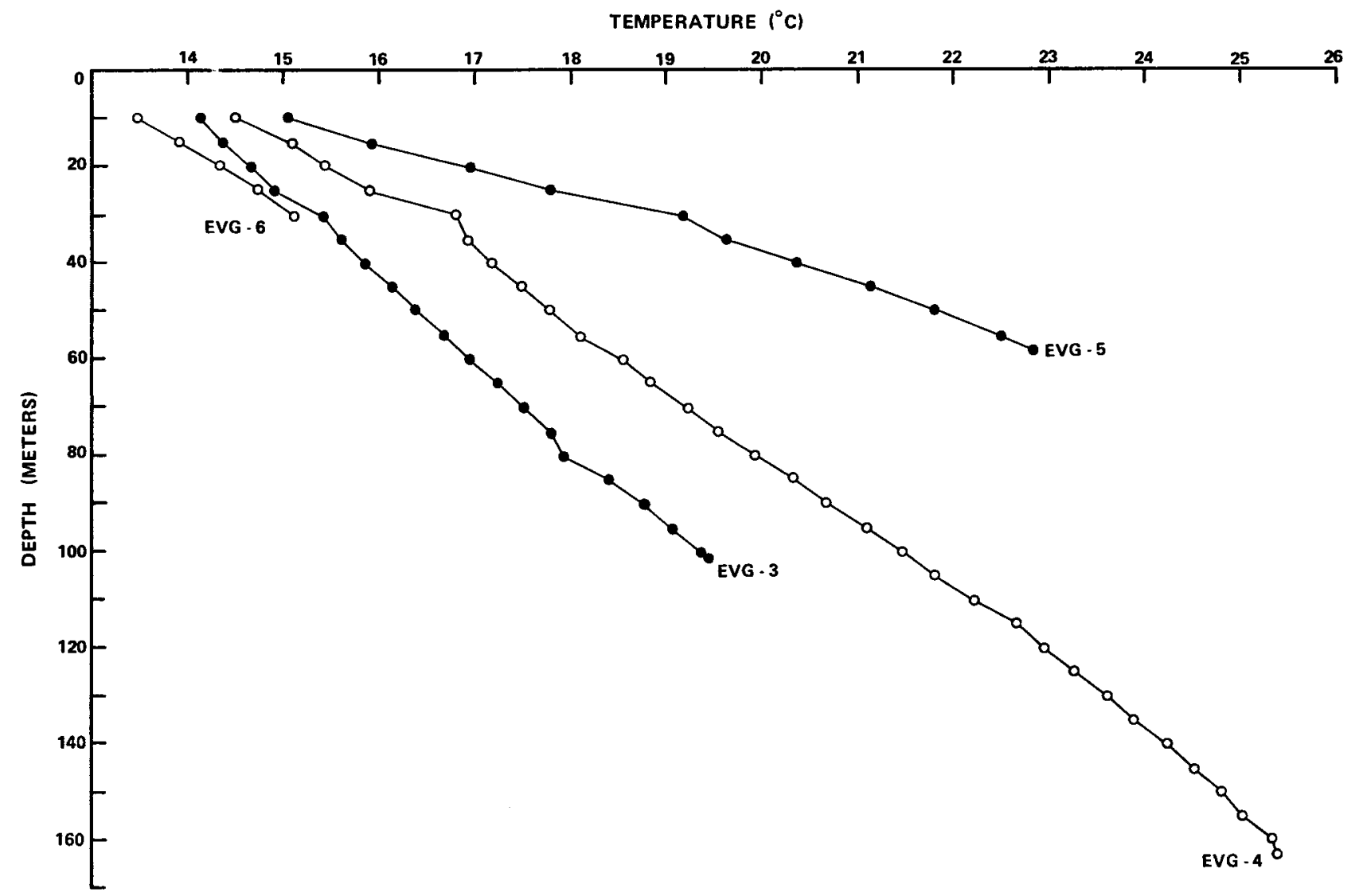

Figure 24. Temperature-depth profiles of "holes of opportunity" logged in Area B (Figure 21) in the Escalante Valley, Utah. 


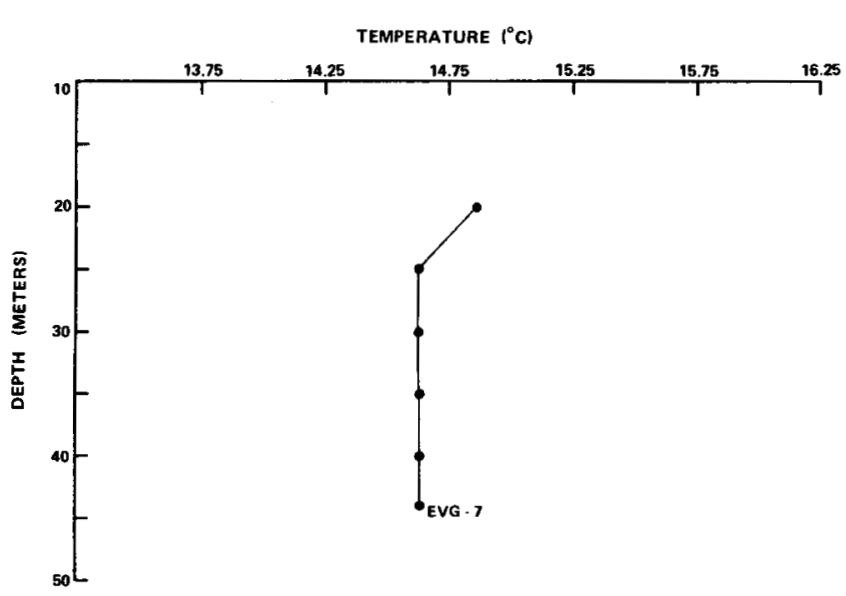

Figure 25. Temperature-depth profile of a "hole of opportunity" logged in Area B (Figure 21) in the Escalante Valley, Utah.

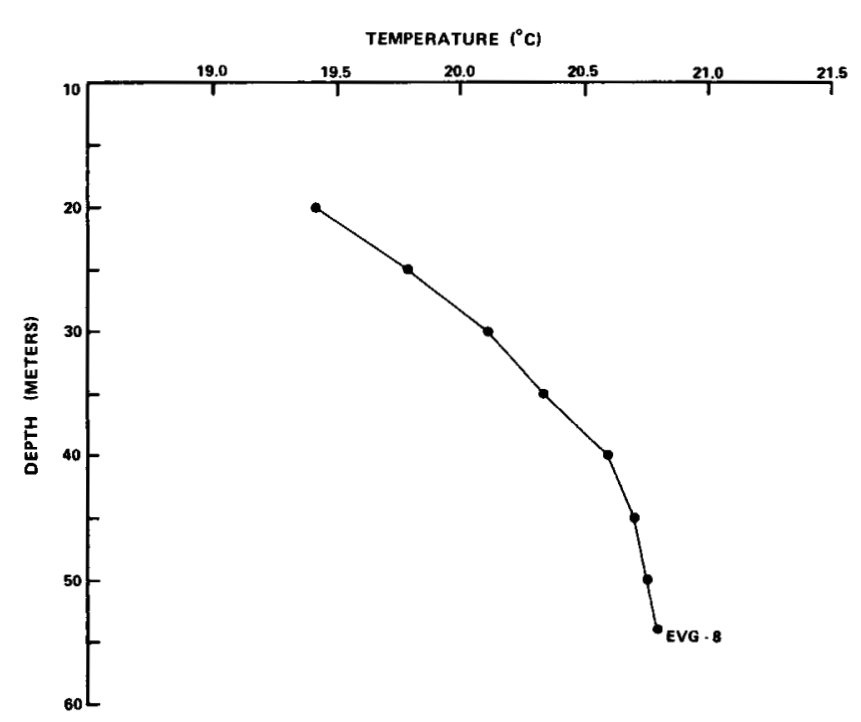

Figure 26. Temperature-depth profile of a "hole of opportunity" logged in Area C (Figure 21) in the Escalante Valley, Utah.

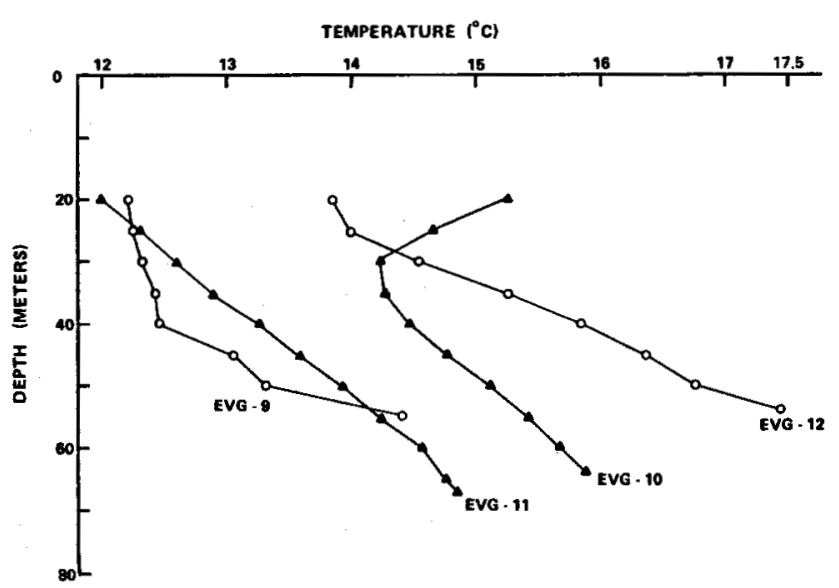

Figure 27. Temperature-depth profiles of "holes of opportunity" logged in Area C (Figure 21) in the Escalante Valley, Utah.

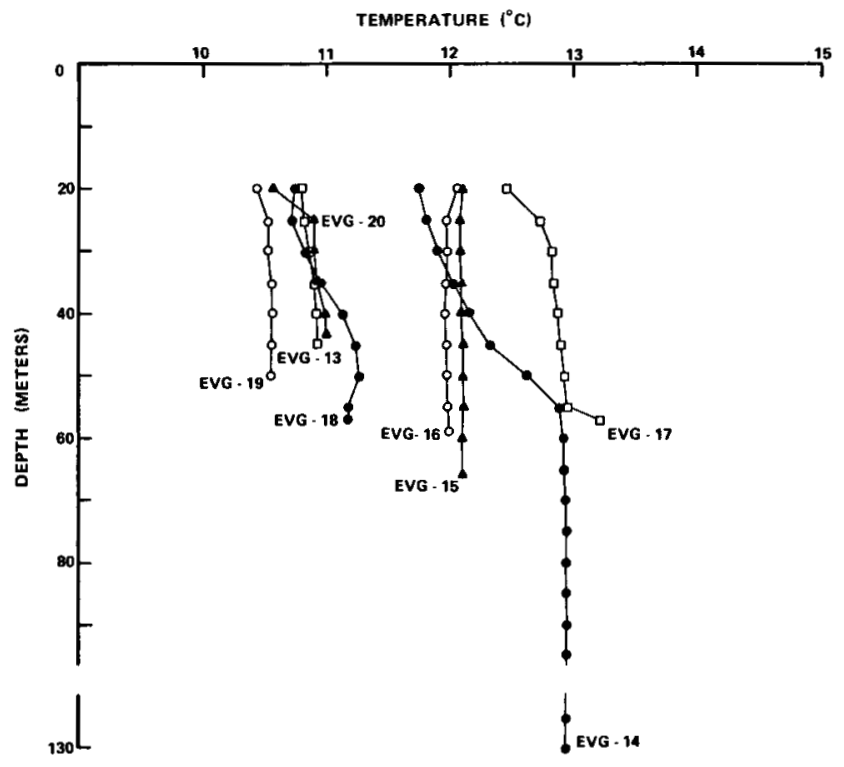

Figure 28. Temperature-depth profiles of "holes of opportunity" logged in Area D (Figure 21) in the Escalante Valley, Utah.

Temperature readings were taken at $16 \mathrm{ft}(5 \mathrm{~m})$ intervals, after the temperature had stabilized at each position. All but hole EVG-3 appeared to be completed in valley alluvium. EVG-3 is a thermal gradient test well drilled into a rhyolite-quartz latite tuff. The gradient holes logged ranged in depth from 98 to 344 $\mathrm{ft}(30$ to $105 \mathrm{~m})$. Ideally gradients should be calculated only for holes greater than $197 \mathrm{ft}(60 \mathrm{~m})$ in depth (Chapman, oral communication, 1982). However, shallower holes can be used to locate areas of nearsurface heat accumulation. In any case, near surface temperature-depth profiles should not be used for

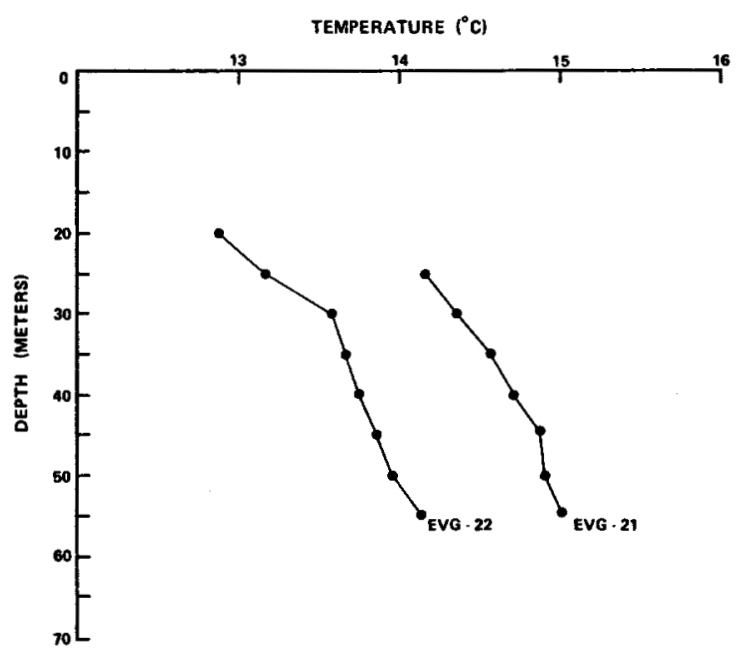

Figure 29. Temperature-depth profiles of "holes of opportunity" logged in Area D (Figure 21) in the Escalante Valley, Utah. 
Table 5. Geothermal gradient data for 22 "holes of opportunity" logged in the Escalante Valley, Utah.

\begin{tabular}{|c|c|c|c|c|c|c|}
\hline Locality & Site & N. Latitude & W. Longitude & $\begin{array}{c}\text { Elevation } \\
\text { (Meters) }\end{array}$ & $\begin{array}{c}\text { Depth } \\
\text { interval for } \\
\text { gradient calc. } \\
\text { (Meters) }\end{array}$ & $\begin{array}{c}\text { Calculated } \\
\text { gradient } \\
\left({ }^{\circ} \mathrm{C} / \mathrm{Km}\right) \\
\end{array}$ \\
\hline Burns Knoll & EVG- 1 & $38^{\circ} 09^{\prime} 46^{\prime \prime}$ & $113^{\circ} 18^{\prime} 06^{\prime \prime}$ & 1566 & $20-44$ & $16 \pm 5$ \\
\hline Lund & EVG- 2 & $38^{\circ} 01^{\prime} 57^{\prime \prime}$ & $113^{\circ} 24^{\prime} 45^{\prime \prime}$ & 1548 & $20-49$ & $46 \pm 3$ \\
\hline \multirow[t]{5}{*}{ Beryl } & EVG- 3 & $37^{\circ} 59^{\prime} 05^{n}$ & $113^{\circ} 39^{\prime} 20^{\prime \prime}$ & 1744 & $30-100$ & $57 \pm 5$ \\
\hline & EVG- 4 & $37^{\circ} 57^{\prime} 11^{\prime \prime}$ & $113^{\circ} 42^{\prime} 39^{\prime \prime}$ & 1665 & $30-160$ & $70 \pm 3$ \\
\hline & EVG- 5 & $37^{\circ} 56^{\prime} 21^{\prime \prime}$ & $113^{\circ} 39^{\prime} 19^{\prime \prime}$ & 1603 & $30-57$ & $138 \pm 10$ \\
\hline & EVG- 6 & $37^{\circ} 58^{\prime} 52^{\prime \prime}$ & $113^{\circ} 34^{\prime} 50^{\prime \prime}$ & 1646 & $10-30$ & $83 \pm 4$ \\
\hline & EVG- 7 & $37^{\circ} 54^{\prime} 51^{\prime \prime}$ & $113^{\circ} 35^{\prime} 48^{\prime \prime}$ & 1576 & $25-44$ & $1 \pm 1.5$ \\
\hline Avon N.W. & EVG- 8 & $37^{\circ} 52^{\prime} 44^{\prime \prime}$ & $113^{\circ} 29^{\prime} 02^{\prime \prime}$ & 1556 & $20-45$ & $52 \pm 9$ \\
\hline \multirow[t]{12}{*}{ Yale Crossing } & EVG- 9 & $37^{\circ} 50^{\prime} 31^{\prime \prime}$ & $113^{\circ} 39^{\prime} 53^{\prime \prime}$ & 1565 & $25-55$ & $94 \pm 44$ \\
\hline & EVG-10 & $37^{\circ} 50^{\prime} 26^{\prime \prime}$ & $113^{\circ} 41^{\prime} 18^{\prime \prime}$ & 1566 & $40-64$ & $60 \pm 3$ \\
\hline & EVG-11 & $37^{\circ} 50^{\prime} 15^{\prime \prime}$ & $113^{\circ} 37^{\prime} 41^{\prime \prime}$ & 1563 & $20-67$ & $63 \pm 4$ \\
\hline & EVG-12 & $37^{\circ} 50^{\prime} 04^{\prime \prime}$ & $113^{\circ} 42^{\prime} 12^{\prime \prime}$ & 1570 & $25-50$ & $114 \pm 10$ \\
\hline & EVG-13 & $37^{\circ} 49^{\prime} 00^{\prime \prime}$ & $113^{\circ} 39^{\prime} 14^{\prime \prime}$ & 1566 & $20-45$ & $6 \pm 3$ \\
\hline & EVG-14 & $37^{\circ} 47^{\prime} 42^{\prime \prime}$ & $113^{\circ} 41^{\prime} 17^{\prime \prime}$ & 1570 & $20-55$ & $32 \pm 7$ \\
\hline & EVG-15 & $37^{\circ} 47^{\prime} 38^{\prime \prime}$ & $113^{\circ} 41^{\prime} 29^{\prime \prime}$ & 1572 & $20-65$ & $0 \pm 1$ \\
\hline & EVG-16 & $37^{\circ} 47^{\prime} 21^{\prime \prime}$ & $113^{\circ} 42^{\prime} 39^{\prime \prime}$ & 1547 & $25-55$ & $0 \pm 1$ \\
\hline & EVG-17 & $37^{\circ} 46^{\prime} 50^{\prime \prime}$ & $113^{\circ} 44^{\prime} 48^{\prime \prime}$ & 1581 & $30-55$ & $5 \pm 1$ \\
\hline & EVG-18 & $37^{\circ} 46^{\prime} 24^{\prime \prime}$ & $113^{\circ} 41^{\prime} 45^{\prime \prime}$ & 1573 & $25-45$ & $26 \pm 4$ \\
\hline & EVG-19 & $37^{\circ} 46^{\prime} 24^{\prime \prime}$ & $113^{\circ} 42^{\prime} 36^{\prime \prime}$ & 1576 & $25-45$ & $2 \pm 1$ \\
\hline & EVG-20 & $37^{\circ} 46^{\prime} 23^{\prime \prime}$ & $113^{\circ} 42^{\prime} 00^{\prime \prime}$ & 1573 & $25-40$ & $6 \pm 4$ \\
\hline \multirow[t]{2}{*}{ Heist } & EVG-21 & $37^{\circ} 45^{\prime} 45^{n}$ & $113^{\circ} 47^{\prime} 24^{\prime \prime}$ & 1595 & $25-45$ & $35 \pm 3$ \\
\hline & EVG-22 & $37^{\circ} 45^{\prime} 41^{\prime \prime}$ & $113^{\circ} 45^{\prime} 06^{\prime \prime}$ & 1584 & $15-30$ & $73 \pm 9$ \\
\hline
\end{tabular}

linear projections of temperature at depth (Greider, 1976). In the study, gradients were calculated for all holes deeper than $147 \mathrm{ft}(45 \mathrm{~m})$ using linear regression; topographic corrections were not employed.

The background gradient in the valley, as determined by Clement (1980), is $56.4^{\circ} \mathrm{C} \mathrm{km}^{-1}$. Comparison of the temperature-depth measurements conducted for this study with the $56.4^{\circ} \mathrm{C} \mathrm{km}^{-1}$ background gradient indicates that at least two areas of elevated temperature exist in the investigated portion of the Escalante Valley.

In the first area, located north of the Union Pacific railroad tracks in the vicinity of Beryl and Zane, four temperature-depth measurements were logged (EVG-3, EVG-4, EVG-5, and EVG-6). See Figure 21 for the locations of these holes and Figure 24 for the temperature-depth profiles. Gradients of $57^{\circ} \mathrm{C}$ $\mathrm{km}^{-1}, 70^{\circ} \mathrm{C} \mathrm{km}^{-1}, 138^{\circ} \mathrm{C} \mathrm{km}^{-1}$, and $83^{\circ} \mathrm{C} \mathrm{km}^{-1}$ were determined for these sites, respectively. These gradients concur with gradients of $78^{\circ} \mathrm{C} \mathrm{km}^{-1}$ and $132^{\circ} \mathrm{C}$ $\mathrm{km}^{-1}$ reported by Clement (1980) for an area between 5.5 and $9.3 \mathrm{mi}(9$ and $15 \mathrm{~km})$ north-northeast of gradient location EVG-6 (Figure 21). EVG-6 is not as deep as other holes, but the gradient calculated $\left(83^{\circ} \mathrm{C}\right.$ $\mathrm{km}^{-1}$ ) is consistent with other temperature-depth profiles measured in this area.
A second area with gradients greater than background is located south of Beryl and includes "holes of opportunity" numbered EVG-9, EVG-10, EVG-11, and EVG-12; gradients calculated are $94^{\circ} \mathrm{C}$ $\mathrm{km}^{-1}, 60^{\circ} \mathrm{C} \mathrm{km}^{-1}, 63^{\circ} \mathrm{C} \mathrm{km}^{-1}$, and $114^{\circ} \mathrm{C} \mathrm{km}^{-1}$, respectively. See Figure 21 for locations and Figure 27 for temperature-depth profiles. The profiles for EVG-9 and EVG-10 indicate ground water disturbance and, therefore, calculated gradients are suspect.

A third area in the vicinity of Beryl Junction, although not exhibiting elevated temperatures, presents a very complex and disturbed ground-water system. The ground-water aquifer in this area is characterized by a large cone of depression caused by heavy pumping for irrigation which has altered the regional flow pattern (Figure 7). Temperature-depth profiles EVG-13, EVG-18, EVG-19, and EVG-20 are somewhat erratic, but generally isothermal (Figure 28). See Figure 21 for locations. Temperature-depth profiles EVG-14, EVG-15, EVG-16, EVG-17, slightly up-gradient in the cone of depression, are also isothermal, but the temperatures are higher (Figure 28). Other temperature-depth profiles measured in the Escalante Valley either indicate disturbances due to ground-water flow or have gradients less than background. 


\section{SUMMARY AND CONCLUSIONS}

Geothermal reconnaissance techniques used in the Escalante Valley have identified an area warranting further investigation as a possible low-to- moderate temperature geothermal resource. This anomaly, northwest of Zane, within area III in Figure 9, is generally depicted by sample locations EV-118, EV-119, and EV-150 in area III on Figure 9. Recorded water temperatures for EV-118, EV-119, and $\mathrm{EV}-150$ were 20,27 , and $28^{\circ} \mathrm{C}\left(68,81\right.$ and $\left.82^{\circ} \mathrm{F}\right)$, respectively. Total dissolved solids (TDS) content is greater than $1000 \mathrm{mg} / \mathrm{l}$ for all wells sampled in area III which is anomalous with the other areas sampled in which concentrations were generally less than $1000 \mathrm{mg} / 1$.

Common ion analysis of water samples delineates three general types of water in the study area. Type I waters are calcium-sodium bicarbonate-chloridesulfate, calcium-sodium chloride-sulfate-bicarbonate and calcium-sodium chloride-sulfate in character. Type II waters consist of samples EV-117 through EV-119 and EV-150 in area III and are sodiumcalcium chloride- sulfate-bicarbonate in character. Type III waters constitute the four samples collected at Thermo Hot Springs and are also sodium-calcium chloride-sulfate- bicarbonate in character. However, Type II waters have significantly higher concentrations of $\mathrm{Ca}$ and $\mathrm{Cl}$.

Trace element analyses show two indicator elements in concentrations favorable for the presence of warm water. Lithium values of some wells in area III (EV-115, EV-117, EV-118, EV-119, and EV-150) range from 0.96 to $1.07 \mathrm{mg} / 1$. These concentrations are similar to those at Thermo Hot Springs which range from 1.18 to $1.26 \mathrm{mg} / 1$. All other samples contained no $\mathrm{Li}$ values greater than $0.21 \mathrm{mg} / \mathrm{l}$. Boron values for samples EV-118, EV-119, and EV-150 are $1.1,1.0$ and $0.9 \mathrm{mg} / 1$ respectively, and are similar to the $1.0 \mathrm{mg} / 1$ value determined for all Thermo Hot Springs samples. Except for samples EV-111 (geothermal test well), EV-115, and EV-146 in area VI, B values were less than $0.61 \mathrm{mg} / 1$ for all remaining samples.

$\mathrm{Na}-\mathrm{K}-\mathrm{Ca}$ (Mg corrected) temperatures computed for samples EV-118, EV-119, and EV-150 were 103, 120 , and $100^{\circ} \mathrm{C}\left(217,248\right.$, and $\left.212^{\circ} \mathrm{F}\right)$, respectively. Temperatures computed for Thermo Hot Springs using this geothermometer ranged from 117 to $127^{\circ} \mathrm{C}$ ( 243 to $261^{\circ} \mathrm{F}$ ). All other samples, with the exception of EV-111 (geothermal exploration well), provided computed temperatures no greater than $74^{\circ} \mathrm{C}\left(165^{\circ} \mathrm{F}\right)$. Quartz (conductive) geothermometer temperatues calculated for $\mathrm{Na}-\mathrm{K}-\mathrm{Ca}$ temperatures greater than $100^{\circ} \mathrm{C}\left(212^{\circ} \mathrm{F}\right)$ for $\mathrm{EV}-118, \mathrm{EV}-119$, and EV-150 ranged from 96 to $104^{\circ} \mathrm{C}\left(205\right.$ to $\left.219^{\circ} \mathrm{F}\right)$ which are consistent with the Na-K-Ca temperatures. The Truesdell and Fournier (1977) mixing model applied to sample EV-118 indicates a potential reservoir temperature of $128^{\circ} \mathrm{C}\left(262^{\circ} \mathrm{F}\right)$ could possibly be expected at depth. This temperature is similar to reservoir temperatures computed for Thermo Hot Springs.

Temperature-depth measurements conducted in the Escalante Valley have identified two areas, other than Thermo Hot Springs, of elevated near surface temperature. One area is northwest of Zane and the other area is approximately $3.1 \mathrm{mi}(5 \mathrm{~km})$ south of Beryl. In the area northwest of Zane, the highest gradient calculated is $138^{\circ} \mathrm{C} \mathrm{km}^{-1}$ which is more than double the background gradient. This temperaturedepth profile is located approximately $0.9 \mathrm{mi}(1.5$ $\mathrm{km})$ west of sample location EV-150 which had a recorded temperature of $28^{\circ} \mathrm{C}\left(82^{\circ} \mathrm{F}\right)$. In the second area of elevated temperature, two of the four gradients calculated apprear to be disturbed by ground water flow. The other exploration techniques employed during this investigation do not indicate a geothermal anomaly at this location.

\section{PROPOSED GEOTHERMAL MODELS FOR THE ZANE AREA}

Model I of the geothermal anomaly indicated northwest of Zane involves meteoric water migration to depth, being warmed by the normal thermal gradient and then rising along a permeable fault zone, coming in contact with a near surface cold water aquifer where mixing occurs and reduces the temperature of the water recorded in the wells sampled (Figure 30). A fault in the vicinity of Zane which may be the conduit for the warmed water, is indicated by Win Pe's (1980) complete Bouguer gravity map of the Escalante Valley (Figure 4). The gravity data indicate a gravity high over the Beryl area which extends to the vicinity of Zane. The southeast border of this gravity high indicates a northeast-southwest striking normal fault, downdropped to the southeast, which extends through the area encompassed by samples EV-118, EV-119, and EV-150.

Model II entails warmed meteoric water migrating up a permeable fault zone and infiltrating a fractured bedrock high and eventually mixing with a cooler, shallow aquifer (Figure 31). Model III involves hot water mixing with cooler water, migrating downgradient and being forced nearer to the surface by the less permeable bedrock high (Figure 32). The warm water is then intercepted by water wells such as EV-118, 119, and 150. This model is modified from 


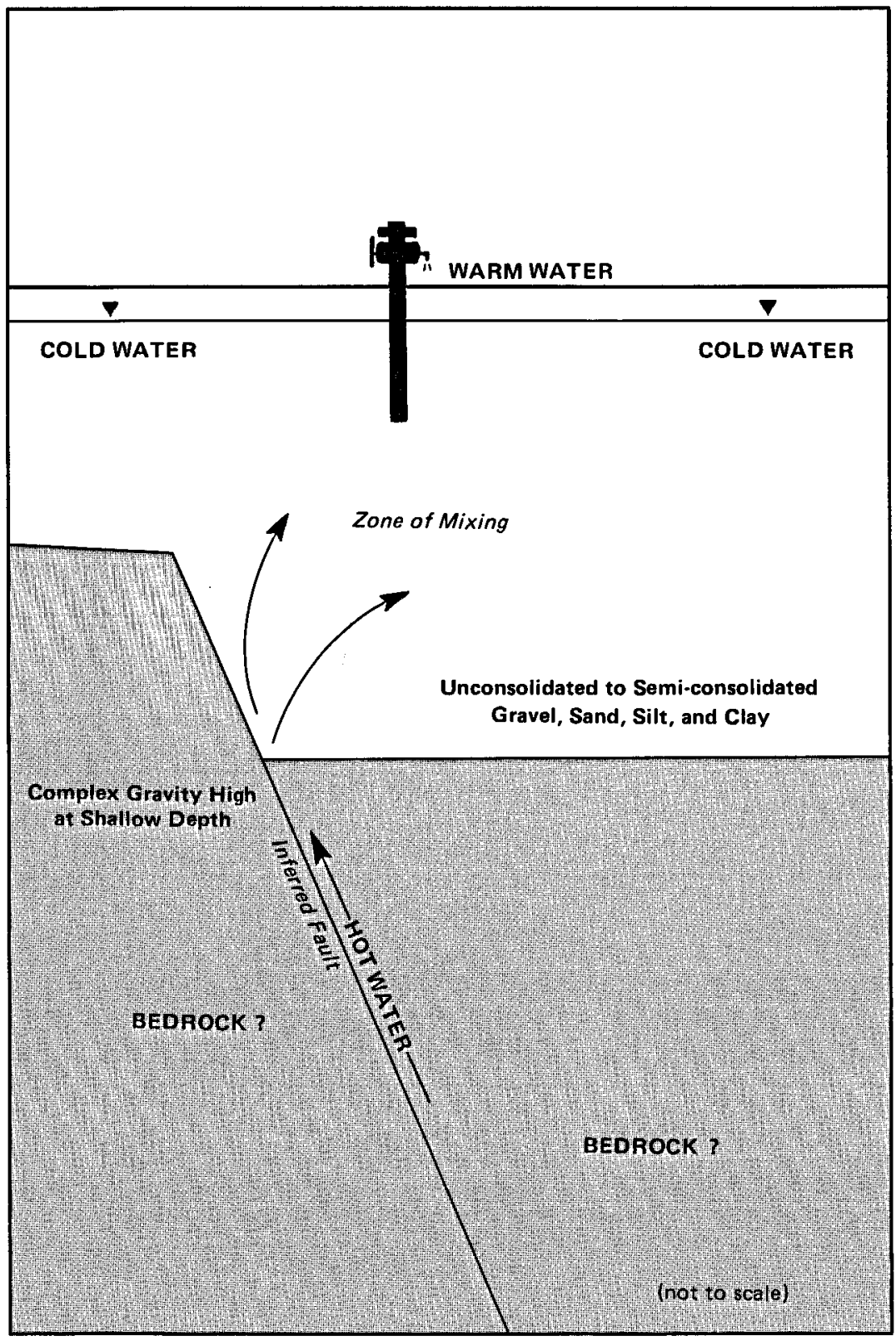

Figure 30. Model I proposed for the geothermal anomaly northwest of Zane, Iron County, Utah.

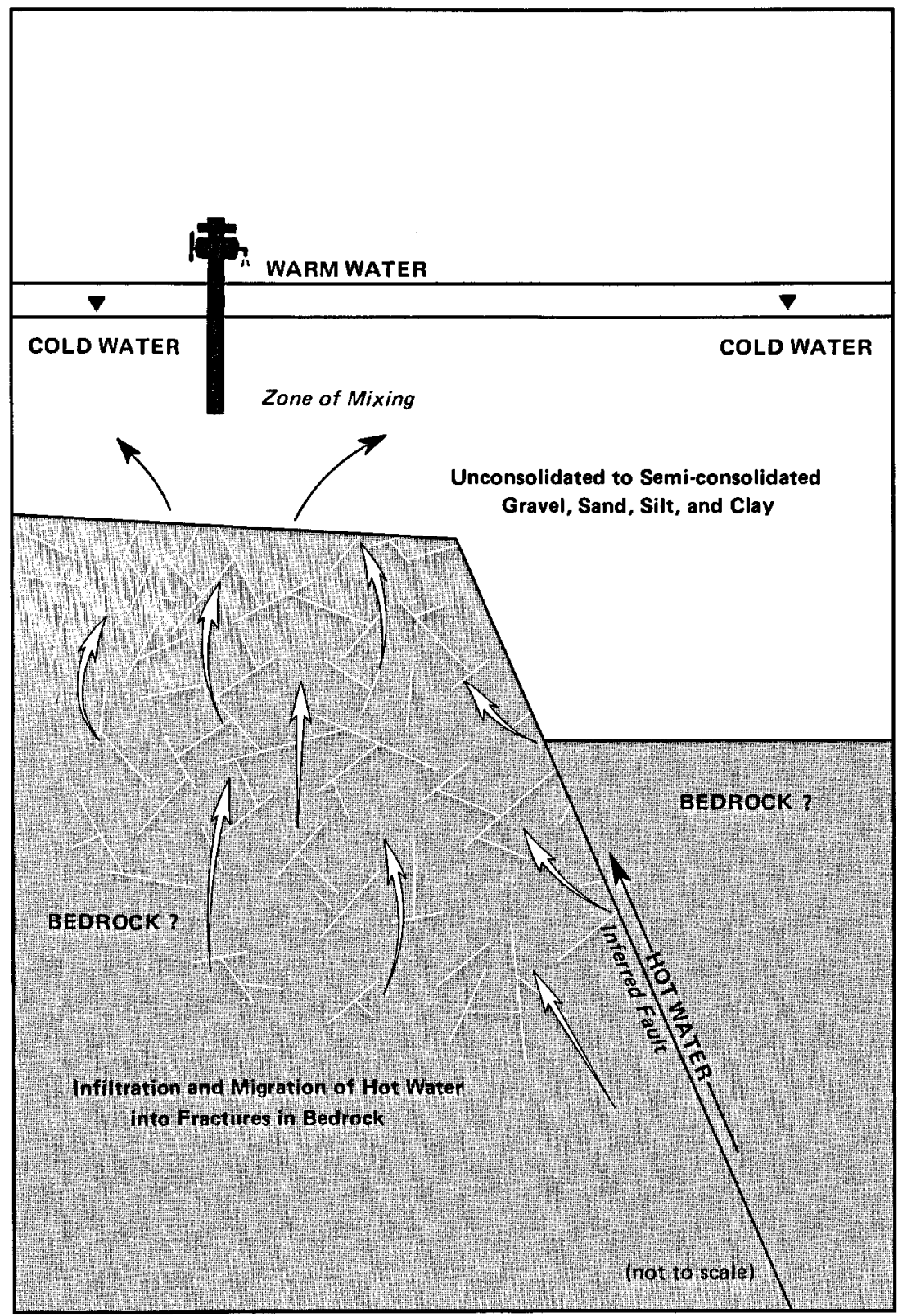

Figure 31. Model II proposed for the geothermal anomaly northwest of Zane, Iron County, Utah. 


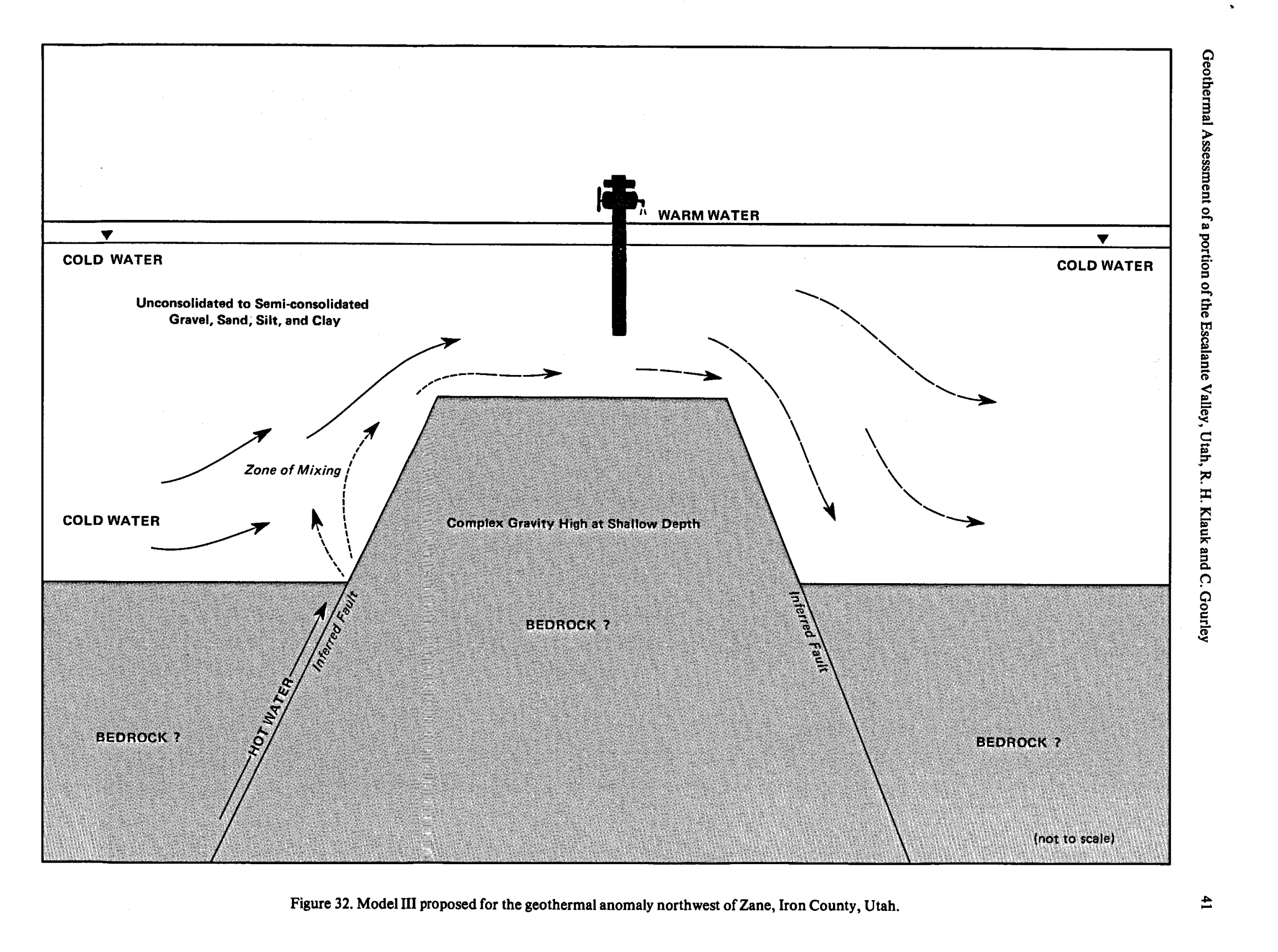


the one proposed by Morgan and others (1981) for the Rio Grande Rift geothermal resources.

\section{FURTHER STUDY}

The exploration techniques used in this study indicate that a low-to-moderate temperature geothermal anomaly exists northwest of Zane. Further research is needed to determine the source of the thermal fluids, to delineate the distribution of these fluids in the near surface, and to determine the maximum temperature.

\section{ACKNOWLEDGEMENTS}

The authors gratefully acknowledge Mary Beth Foreman, Ruth Kroneman, and Linda Scholl Moore for water sampling, analysis, and initial illustration preparation, respectively. Gratitude is extended to Dr. David Chapman for help in interpreting the temperature-depth data. Finally, appreciation goes to Dr. Duncan Foley, Carl Ruscotta, and Regina Capuana for their careful review of the manuscript.

\section{REFERENCES CITED}

Anderson, R. E., and Bucknam, 1979, Two areas of probable Holocene deformation in southwestern Utah: Tectonophysics, v. 52, p. 417-430.

Anderson, R. E., and Mehnert, H. H., 1979, Reinterpretation of the history of the Hurricane fault: in Newman, G. W., and Goode, H. D., Basin and Range symposium and Great Basin field conference: Rocky Mountain Association of Geologists and Utah Geological Association, p. 145-173.

Anderson, L. W., and Miller, D. G., 1979, Quaternary map of Utah: Fugro, Inc., Consulting Engineers and Geologists, Long Beach, California.

Armstrong, R. L., 1968, Sevier orogenic belt in Nevada and Utah: Geological Society of American Bulletin, $\mathbf{v}$. 79 , p. $429-458$.

Arnorsson, S., 1975, Application of the silica geothermometer in low temperature hydrothermal areas in Iceland: American Journal of Science, v. 275, p. 763-784.

Clement, M. D., 1980, Escalante Desert: Heat flow and geothermal assessment of the Oligocene/Miocene volcanic belt in southwestern Utah: Salt Lake City, University of Utah, M. S. thesis, $118 \mathrm{p}$.

Crosby, G. W., 1973, Regional structure in southwestern Utah: Utah Geological Association publication 3, p. 27-32.

1976, Tectonic evolution in Utah's miogeosyncline - shelf boundary zone: in Hill, J. G., ed., Symposium on geology of the Cordilleran hingeline: Rocky Mountain Association of Geologists, p. 27-36.

Ekren, E. B., Bucknam, R. C., Carr, W. J., Dixon, G. L., and Quinlivan, W. D., 1976, East-trending structural lineaments in central Nevada: U.S. Geological Survey Professional Paper 986, $16 \mathrm{p}$.

Fournier, R. O., White, D. E., and Truesdell, A. H., 1974, Geochemical indicators of subsurface temperature part 1, basic assumptions: U.S. Geological Survey Journal Research, v. 2, p. 259-262.

Fournier, R. O., 1977, Chemical geothermometers and mixing models for geothermal systems: Geothermics, v. 5, p. 41-50.

Fournier, R. O., 1981, Application of water geochemistry to geothermal systems, in Rybach, L., and Muffler,
L.J.P., eds., Geothermal systems principals and case histories: New York, John Wiley and Sons, p. 109-143.

Fournier, R. O., and Potter, R. W., II, 1979, Magnesium correction to the Na-K-Ca chemical geothermometer: Geochemica et Cosmochimica Acta, vol. 43, p. 1543-1550.

Greider, B., 1976, Geothermal energy Cordilleran hinglinewest: in Hill, J. G., ed, Symposium on geology of the Cordilleran hingeline: Rocky Mountain Association of Geologists, p. 351-362.

Hintze, L. F., 1963a, Lower Paleozoic of southwestern Utah: in Heylmun, E. B., ed., Guidebook to the geology of southwestern Utah: Intermountain Association of Petroleum Geologists, p. 26-29.

1963b, compiler, Geologic map SW quarter Utah: Utah Geologic and Mineral Survey, scale 1:500,000.

1973, Geologic history of Utah: Brigham Young University Geology Studies, v. 20, pt. 3, 181 p.

Kappelmeyer, O., and Haenel, R., 1974, Geothermics with special reference to application: Berlin, Gebruder Borntraeger, $238 \mathrm{p}$.

Kay, M., 1951, North American geosynclines: Geologic Society of America Memoir 48, $143 \mathrm{p}$.

Laughlin, A. W., 1982, Exploration for geothermal energy, in Handbook of geothermal energy: Houston, Gulf Publishing Company, p. 230.

Lumb, J. T., 1981, Exploration for geothermal energy, in Ryback, L., and Muffler, L. J. P., eds., Handbook of Geothermal Energy: Gulf Publishing Company, p. 230.

Mackin, J. H., 1947, Some structural features of the intrusions in the Iron Springs district: Utah Geological Society Guidebook to the Geology of Utah, no. 2, 62 p.

Miller, G. M., 1963, Outline of structural-stratigraphic units of the Wah Wah Mountains, southwestern Utah: in Heylmun, E. B., ed., Guidebook to the geology of southwestern Utah: Intermountain Association of Petroleum Geologists, 12th Annual Field Conference, p. 96-102.

1966, Structure and stratigraphy of southern part of Wah Wah Mountains; southern Utah: American Association Petroleum Geologists Bulletin, v. 50, no. 5, p. 858-900. 
Morgan P, Harder, V., Swanberg, C. A., and Daggett, P. H., 1981, A groundwater convection model for Rio Grande Rift geothermal resources: Geothermal Resources Council, Transactions vol. 5, p. 193-196.

Mower, R. W., 1981, Hydrology of the Beryl-Enterprise area, Escalante Desert, Utah, with emphasis on ground water: U.S. Geological Survey Open-File Report 81-533, 81 p.

1982, Hydrology of the Beryl-Enterprise area, Escalante Desert, Utah, with emphasis on ground water: State of Utah, Dept. of Natural Resources, Technical Publication No. 73, 66 p.

Mundorff, J. C., 1970, Major thermal springs of Utah: Utah Geological and Mineral Survey Water-Resources Bulletin $13,60 \mathrm{p}$.

Rowley, P. D., 1975, Geologic setting of the Thermo KGRA (known geothermal resource area), Beaver County, Utah (abs.): Geological Society of America Abstracts with Programs, v. 7, no. 7, p. 1254.

Rowley, P. D., Anderson, J. J., Williams, P. L., and Fleck, R. J., 1978, Age of structural differentiation between the Colorado Plateaus and Basin and Range provinces in southwestern Utah: Geology, v. 6, p. 51-55.

Rowley, P. D., Steven, T. A., Anderson, J. J., Cunningham, C. G., 1979, Cenozoic stratigraphic and structural framework of southwestern Utah: U.S. Geological Survey Professional Paper 1149, 22 p.

Rush, F. E., 1977, Subsurface-temperature data for some wells in western Utah: U.S. Geological Survey OpenFile Report, no. 77-132, 63 p.

Sonderegger, J. L., and Donovan, J. J., 1981, Problems of trace element ratios and geothermometry in a gravel geothermal-aquifer system: in Ruscetta, C. A., and Foley, Duncan, eds., Glenwood technical conference proceedings, v. 1, state-coupled geothermal resource assessment program: Earth Science Laboratory, University of Utah Research Institute, Salt Lake City, Utah, p. 50-62.

Stewart, J. H., and Poole, F. G., 1974, Lower Paleozoic and uppermost Pre-cambrian Cordilleran miogeosyncline, Great Basin, western United States: Society of Economic Paleontologists and Mineralogists, Special Publication 22, p. 28-57.

Stokes, W. L., 1963, Triassic and Jurassic formations of southwestern Utah: in Heylmun, E. B.., ed, Guidebook to the geology of southwestern Utah: Intermountain Association Petroleum Geologists, 12th Annual Field Conference, p. 60-64.

1976, What is the Wasatch Line: in Hill, J. G., ed, Symposium on geology of the Cordilleran hingeline: Rocky Mountain Association of Geologists, p. 11-25.

Stokes, W. L., and Heylmun, E. B., 1963, Tectonic history of southwestern Utah: in Heylmún, E. B., ed., Guidebook to the geology of southwestern Utah: Intermountain Assoc. Petroleum Geologists, 12th Annual Field Conference, p. 19-25.

Truesdell, A. H., and Fournier, F. O., 1977, Procedure for estimating the temperature of a hot-water component in a mixed water by using a plot of dissolved silica versus enthalpy: U.S. Geological Survey Journal of Research, v. 5, no. 1, p. 49-52.

Welsh, John E., 1959, Biostratigraphy of the Pennsylvanian and Permian Systems in southern Nevada: Salt Lake City, University of Utah, Ph. D. dissertation, $106 \mathrm{p}$.

Win Pe, 1980, Gravity survey of the Escalante Desert and vicinity in Iron and Washington Counties, Utah: Salt Lake City, University of Utah M.S. Thesis, 151 p. 
APPENDIX A

WELL- AND SPRING-NUMBERING SYSTEM 


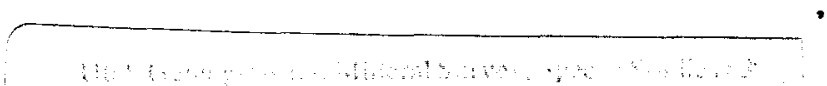




\section{WELL- AND SPRING-NUMBERING SYSTEM}

The system of numbering wells and springs in Utah is based on the cadastral land-survey system of the U.S. Government. The number, in addition to designating the well or spring, describes its position in the land net. By the land-survey system, the State is divided into four quadrants by the Salt Lake Base Line and Meridian, and these quadrants are designated by uppercase letters as follows: A, northeast; B, northwest; C, southwest; and D, southeast. Numbers designating the township and range (in that order) follow the quadrant letter, and all three are enclosed in parentheses. The number after the parentheses indicates the section, and is followed by three letters indicating the quarter section, the quarter-quarter section, and the quarter- quarter-quarter section, generally 10 acres $\left(4 \mathrm{hm}^{2}\right)$; the quarters of each sub- division are designated by lowercase letters as follows: a, northeast; $b$, northwest; c, southwest; and $d$, southeast. The number after the letters is the serical number of the well or spring within the 10 -acre (4-hm²) tract; the letter" $\mathrm{S}$ " preceding the serial number denotes a spring. Thus (C-36-16) 36 add -1 designated the first well constructed or visited in the SE1/4SE1/4NE1/4 sec. 36, T. 36 S., R. 16 W. If a well or spring cannot be located within a 10 -acre $\left(4-\mathrm{hm}^{2}\right)$ tract, one or two location letters are used and the serial number is omitted. Other sites where hydrologic data were collected, are numbered in the same manner, but three letters are used after the section number and no serial number is used. The numbering system is illustrated in figure A-1 (after Mower, 1982).

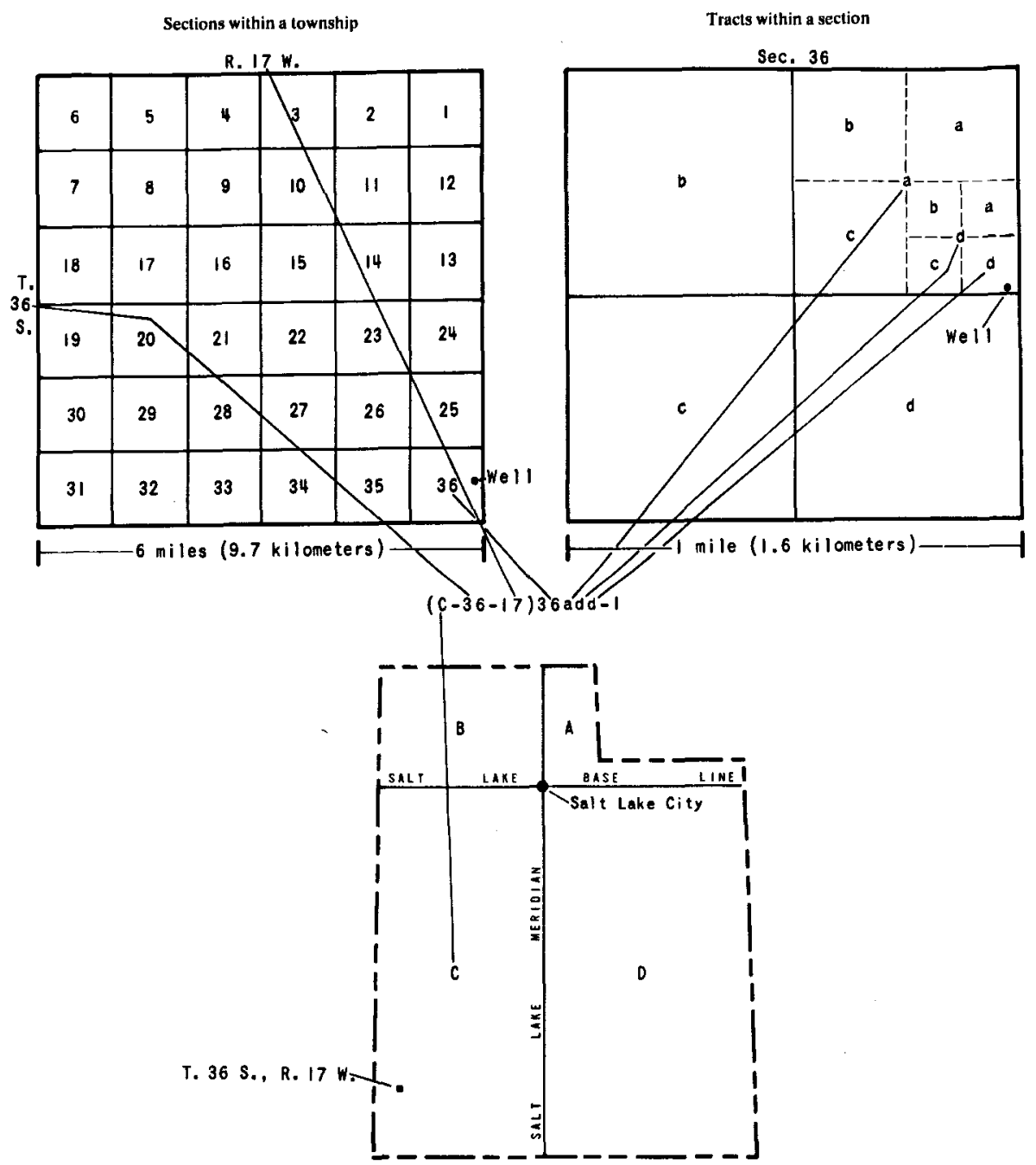

Figure A-1. Well-, spring-, and other data site-numbering system used in Utah. 
APPENDIX B

TEMPERATURE-DEPTH PROFILE DATA 
$\sqrt{x}$

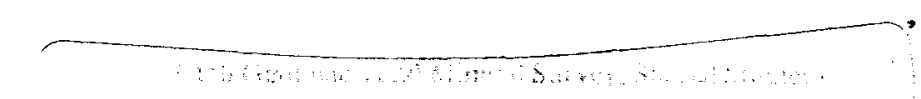


B-2

Area: Iron County, Utah

Cadastral: T34S/R16W.S18 cdb

Site Name: Escalante Valley EVG-1

Latitude: $37^{\circ} 09^{\prime} 46^{\prime \prime} \mathrm{N}$.

Longitude: $113^{\circ} 18^{\prime} 06^{\prime \prime} \mathrm{W}$.

Elevation: $1566 \pm 0.7 \mathrm{~m}$

Depth to Water: $10 \mathrm{~m} \pm 2.5$

Depth Range (Grad. Calc.): 20 - 44

Gradient: $16 \pm 5 \mathrm{C} / \mathrm{km}$

Drilling Completed by:

Thermal Logging Date: 10-28-81

\begin{tabular}{cc}
$\begin{array}{c}\text { Depth } \\
\text { (m) }\end{array}$ & $\begin{array}{c}\text { T } \\
\text { (C) }\end{array}$ \\
\hline 0 & 16.79 \\
10 & 13.89 \\
15 & 13.78 \\
20 & 13.78 \\
25 & 13.84 \\
30 & 13.92 \\
35 & 13.99 \\
40 & 14.04 \\
44 & 14.18
\end{tabular}

Area: Iron County, Utah

Cadastral: T32S/R16W/S28 ccc

Site Name: Escalante Valley EVG-3

Latitude: $37^{\circ} 59^{\prime} 05^{\prime \prime} \mathrm{N}$.

Longitude: $113^{\circ} 39^{\prime} 20^{\prime \prime} \mathrm{W}$.

Elevation: $1744 \pm 0.7 \mathrm{~m}$

Depth to Water: $25 \mathrm{~m} \pm 2.5$

Depth Range (Grad. Calc.): 30 - 100m

Gradient: $57 \pm 5 \mathrm{C} / \mathrm{km}$

Drilling Completed by: 10-2-78

Thermal Logging Date: 11-19-81

\begin{tabular}{rc}
$\begin{array}{c}\text { Depth } \\
(\mathbf{m})\end{array}$ & $\begin{array}{c}\text { T } \\
(\mathbf{C})\end{array}$ \\
\hline 0 & 14.49 \\
10 & 14.15 \\
15 & 14.39 \\
20 & 14.68 \\
25 & 14.89 \\
30 & 15.44 \\
35 & 15.60 \\
40 & 15.87 \\
45 & 16.15 \\
50 & 16.41 \\
55 & 16.70 \\
60 & 16.96 \\
65 & 17.27 \\
70 & 17.53 \\
75 & 17.79 \\
80 & 17.95 \\
85 & 18.42 \\
90 & 18.76 \\
95 & 19.08 \\
100 & 19.37 \\
102 & 19.44
\end{tabular}

Area: Iron County, Utah

B-3

Cadastral: T32S/R14W/S10 cbd

Site Name: Escalante Valley EVG-2

Latitude: $38^{\circ} 01^{\prime} 57^{\prime \prime} \mathrm{N}$.

Longitude: $113^{\circ} 24^{\prime} 45^{\prime \prime} \mathrm{W}$.

Elevation: $1548 \pm 0.7 \mathrm{~m}$

Depth to Water: $10 \mathrm{~m} \pm 2.5$

Depth Range (Grad. Calc.) : 20 - 49m

Gradient: $46 \pm 3 \mathrm{C} / \mathrm{km}$

Drilling Completed by:

Thermal Logging Date: 11-17-81

$\mathbf{T}$

(C)

17.59

11.75

11.79

12.01

12.27

12.45

12.69

12.91

13.15

13.37 
Area: Iron County, Utah

Cadastral: T33S/R17W/S2 ddc

Site Name: Escalante Valley EVG-4

Latitude: $37^{\circ} 57^{\prime} 11^{\prime \prime} \mathrm{N}$.

Longitude: $113^{\circ} 42^{\prime} 39^{\prime \prime} \mathrm{W}$.

Elevation: $1665 \pm 0.7 \mathrm{~m}$

Depth to Water: $25 \mathrm{~m} \pm 2.5$

Depth Range (Grad. Calc.) : 30 - 160m

Gradient: $70 \pm 3 \mathrm{C} / \mathrm{km}$

Drilling Completed by: 9-?-81

Thermal Logging Date: 11-19-81

\begin{tabular}{rc}
$\begin{array}{c}\text { Depth } \\
\text { (m) }\end{array}$ & $\begin{array}{c}\text { T } \\
(\mathbf{C})\end{array}$ \\
\hline 0 & 14.51 \\
10 & 14.51 \\
15 & 15.10 \\
20 & 15.43 \\
25 & 15.91 \\
30 & 16.82 \\
35 & 16.95 \\
40 & 17.16 \\
45 & 17.46 \\
50 & 17.79 \\
55 & 18.12 \\
60 & 18.57 \\
65 & 18.85 \\
70 & 19.22 \\
75 & 19.57 \\
80 & 19.94 \\
85 & 20.32 \\
90 & 20.69 \\
95 & 21.10 \\
100 & 21.47 \\
105 & 21.81 \\
110 & 22.20 \\
115 & 22.58 \\
120 & 22.97 \\
125 & 23.24 \\
130 & 23.60 \\
135 & 23.91 \\
140 & 24.25 \\
145 & 24.53 \\
150 & 24.82 \\
155 & 25.03 \\
160 & 25.37 \\
163 & 25.39 \\
& \\
\hline 0 & \\
&
\end{tabular}

B-5

Area: Iron County, Utah

Cadastral: T33S/R16W/S2 bbb

Site Name: Escalante Valley EVG-5

Latitude: $37^{\circ} 56^{\prime} 21^{\prime \prime} \mathrm{N}$.

Longitude: $113^{\circ} 39^{\prime} 19^{\prime \prime} \mathrm{W}$.

Elevation: $1603 \pm 0.7 \mathrm{~m}$

Depth to Water: $30 \mathrm{~m} \pm 2.5$

Depth Range (Grad. Calc.): 30 - 57m

Gradient: $138 \pm 10 \mathrm{C} / \mathrm{km}$

Drilling Completed by:

Thermal Logging Date: 12-1-81

\begin{tabular}{cc}
$\begin{array}{c}\text { Depth } \\
\text { (m) }\end{array}$ & $\begin{array}{c}\text { T } \\
\text { (C) }\end{array}$ \\
\hline 0 & - \\
10 & 15.04 \\
15 & 15.93 \\
20 & 16.97 \\
25 & 17.81 \\
30 & 19.19 \\
35 & 19.65 \\
40 & 20.38 \\
45 & 21.15 \\
50 & 21.82 \\
55 & 22.50 \\
57 & 22.83
\end{tabular}

Area: Iron County, Utah

Cadastral: T32S/R15W/S31 bbb

Site Name: Escalante Valley EVG-6

Latitude: $37^{\circ} 58^{\prime} 52^{\prime \prime} \mathrm{N}$.

Longitude: $113^{\circ} 34^{\prime} 50^{\prime \prime} \mathrm{W}$.

Elevation: $1646 \pm 0.7 \mathrm{~m}$

Depth to Water: $25 \mathrm{~m} \pm 2.5$

Depth Range (Grad. Calc.): 10 - 30m

Gradient: $83 \pm 4 \mathrm{C} / \mathrm{km}$

Drilling Completed by:

Thermal Logging Date: 11-20-81

\begin{tabular}{cc}
$\begin{array}{c}\text { Depth } \\
\text { (m) }\end{array}$ & $\begin{array}{c}\text { T } \\
\text { (C) }\end{array}$ \\
\hline 0 & - \\
10 & 13.47 \\
15 & 13.91 \\
20 & 14.36 \\
25 & 14.72 \\
30 & 15.14
\end{tabular}


Area: Iron County, Utah

Cadastral: T33S/R16W/S24 cca

Site Name: Escalante Valley EVG-7

Latitude: $37^{\circ} 54^{\prime} 51^{\prime \prime} \mathrm{N}$.

Longitude: $113^{\circ} 35^{\prime} 48^{\prime \prime} \mathrm{W}$.

Elevation: $1576 \pm 0.7 \mathrm{~m}$

Depth to Water: $25 \mathrm{~m} \pm 2.5$

Depth Range (Grad. Calc.): 25 - 44m

Gradient: $0.62 \pm 2 \mathrm{C} / \mathrm{km}$

Drilling Completed by:

Thermal Logging Date: 11-24-81

\begin{tabular}{cc}
$\begin{array}{c}\text { Depth } \\
(\mathbf{m})\end{array}$ & $\begin{array}{c}\text { T } \\
\text { (C) }\end{array}$ \\
\hline 0 & 12.94 \\
10 & 15.75 \\
15 & 15.61 \\
20 & 14.86 \\
25 & 14.63 \\
30 & 14.63 \\
35 & 14.63 \\
40 & 14.63 \\
44 & 14.64
\end{tabular}

Area: Iron County, Utah

Cadastral: T34S/R15W/S1 bac

Site Name: Escalante Valley EVG-8

Latitude: $37^{\circ} 52^{\prime} 44^{\prime \prime} \mathrm{N}$.

Longitude: $113^{\circ} 29^{\prime} 02^{\prime \prime} \mathrm{W}$.

Elevation: $1556 \pm 0.7 \mathrm{~m}$

Depth to Water: $10 \mathrm{~m} \pm 2.5$

Depth Range (Grad. Calc.): 20 - 45m

Gradient: $52 \pm 9 \mathrm{C} / \mathrm{km}$

Drilling Completed by:

Thermal Logging Date: 11-11-81

\begin{tabular}{cc}
$\begin{array}{c}\text { Depth } \\
(\mathbf{m})\end{array}$ & $\begin{array}{c}\text { T } \\
(\mathbf{C})\end{array}$ \\
\hline 0 & 12.39 \\
10 & 18.59 \\
15 & 19.01 \\
20 & 19.42 \\
25 & 19.79 \\
30 & 20.12 \\
35 & 20.34 \\
40 & 20.60 \\
45 & 20.71 \\
50 & 20.76 \\
54 & 20.80
\end{tabular}

Area: Iron County, Utah

Cadastral: T34S/R16W/S17 cda

Site Name: Escalante Valley EVG-9

Latitude: $37^{\circ} 50^{\prime} 31^{\prime \prime} \mathrm{N}$.

Longitude: $113^{\circ} 39^{\prime} 53^{\prime \prime} \mathrm{W}$.

Elevation: $1565 \pm 0.7 \mathrm{~m}$

Depth to Water: $8 \mathrm{~m} \pm 2.5$

Depth Range (Grad. Calc.) : 25 - 55m

Gradient: $94 \pm 44 \mathrm{C} / \mathrm{kmest} .72 \mathrm{C} / \mathrm{km}$

Drilling Completed by:

Thermal Logging Date: 11-9-81

\begin{tabular}{cc}
$\begin{array}{c}\text { Depth } \\
\text { (m) }\end{array}$ & $\begin{array}{c}\text { T } \\
\text { (C) }\end{array}$ \\
\hline 0 & - \\
10 & 12.06 \\
15 & 12.15 \\
20 & 12.19 \\
25 & 12.26 \\
30 & 12.32 \\
35 & 12.44 \\
40 & 12.56 \\
45 & 13.06 \\
50 & 13.31 \\
55 & 14.41
\end{tabular}

B-11

B-9 Area: Iron County, Utah

Cadastral: T34S/R16W/S18 cdb

Site Name: Escalante Valley EVG-10

Latitude: $37^{\circ} 50^{\prime} 26^{\prime \prime} \mathrm{N}$.

Longitude: $113^{\circ} 41^{\prime} 18^{\prime \prime} \mathrm{W}$.

Elevation: $1566 \pm 0.7 \mathrm{~m}$

Depth to Water: $10 \mathrm{~m} \pm 2.5$

Depth Range (Grad. Calc.): 40 - 64m

Gradient: $60 \pm 3 \mathrm{C} / \mathrm{km}$

Drilling Completed by: 5-10-76

Thermal Logging Date: 10-26-81

\begin{tabular}{cc}
$\begin{array}{c}\text { Depth } \\
(\mathbf{m})\end{array}$ & $\begin{array}{c}\text { T } \\
\text { (C) }\end{array}$ \\
\hline 0 & 17.23 \\
10 & 15.52 \\
15 & 15.61 \\
20 & 15.26 \\
25 & 14.66 \\
30 & 14.25 \\
35 & 14.29 \\
40 & 14.47 \\
45 & 14.78 \\
50 & 15.11 \\
55 & 15.43 \\
60 & 15.68 \\
64 & 15.89
\end{tabular}




\section{B-12}

Area: Iron County, Utah

Cadastral: T34S/R16W/S22 abb

Site Name: Escalante Valley EVG-11

Latitude: $37^{\circ} 50^{\prime} 15^{\prime \prime} \mathrm{N}$.

Longitude: $113^{\circ} 37^{\prime} 41^{\prime \prime} \mathrm{W}$.

Elevation: $1563 \pm 0.7 \mathrm{~m}$

Depth to Water: $9 \mathrm{~m} \pm 2.5$

Depth Range (Grad. Calc.): 20 - 67m

Gradient: $63 \pm 4 \mathrm{C} / \mathrm{km}$

Drilling Completed by:

Thermal Logging Date: 10-30-81

\begin{tabular}{cc}
$\begin{array}{c}\text { Depth } \\
\text { (m) }\end{array}$ & $\begin{array}{c}\text { T } \\
\text { (C) }\end{array}$ \\
\hline 0 & 12.96 \\
10 & 11.58 \\
20 & 12.00 \\
25 & 12.31 \\
30 & 12.60 \\
35 & 12.91 \\
40 & 13.27 \\
45 & 13.60 \\
50 & 13.93 \\
55 & 14.24 \\
60 & 14.59 \\
65 & 14.78 \\
67 & 14.84
\end{tabular}

B-13

Area: Iron County, Utah

Cadastral: T34S/R16W/S28 bcc

Site Name: Escalante Valley EVG-13

Latitude: $37^{\circ} 49^{\prime} 00^{\prime \prime} \mathrm{N}$.

Longitude: $113^{\circ} 39^{\prime} 14^{\prime \prime} \mathrm{W}$.

Elevation: $1566 \pm 0.7 \mathrm{~m}$

Depth to Water: $10 \mathrm{~m} \pm 2.5$

Depth Range (Grad. Calc.) : 20 - 45m

Gradient: $6 \pm 3 \mathrm{C} / \mathrm{km}$

Drilling Completed by: $2-4-75$

Thermal Logging Date: 11-5-81

\begin{tabular}{cc}
$\begin{array}{c}\text { Depth } \\
(\mathbf{m})\end{array}$ & $\begin{array}{c}\text { T } \\
(\mathbf{C})\end{array}$ \\
\hline 0 & 17.24 \\
10 & 12.26 \\
15 & 10.74 \\
20 & 10.79 \\
25 & 10.82 \\
30 & 10.85 \\
35 & 10.93 \\
40 & 10.93 \\
45 & 10.93
\end{tabular}

Area: Iron County, Utah

Cadastral: T34S/R17W/S24 bdb

Site Name: Escalante Valley EVG-12

Latitude: $37^{\circ} 50^{\prime} 04^{\prime \prime} \mathrm{N}$.

Longitude: $113^{\circ} 42^{\prime} 12^{\prime \prime} \mathrm{W}$.

Elevation: $1570 \pm 0.7 \mathrm{~m}$

Depth to Water: $9 \mathrm{~m} \pm 2.5$

Depth Range (Grad. Calc.) : 25 - 50m

Gradient: $114 \pm 10 \mathrm{C} / \mathrm{km}$

Drilling Completed by: 12-9-74

Thermal Logging Date: 11-9-81

\begin{tabular}{cc}
$\begin{array}{c}\text { Depth } \\
\text { (m) }\end{array}$ & $\begin{array}{c}\text { T } \\
(\mathbf{C})\end{array}$ \\
\hline 0 & 12.71 \\
10 & 13.12 \\
15 & 13.72 \\
20 & 13.85 \\
25 & 13.99 \\
30 & 14.55 \\
35 & 15.26 \\
40 & 15.85 \\
45 & 16.37 \\
50 & 16.76 \\
54 & 17.45
\end{tabular}


Area: Iron County, Utah

Cadastral: T34S/R16W/S31 ccd

Site Name: Escalante Valley EVG-14

Latitude: $37^{\circ} 47^{\prime} 42^{\prime \prime} \mathrm{N}$.

Longitude: $113^{\circ} 41^{\prime} 17^{\prime \prime} \mathrm{W}$.

Elevation: $1570 \pm 0.7 \mathrm{~m}$

Depth to Water: $17 \mathrm{~m} \pm 2.5$

Depth Range (Grad. Calc.) : 20 - 55m

Gradient: $32 \pm 7 \mathrm{C} / \mathrm{km}$

Drilling Completed by: 6-21-76

Thermal Logging Date: 11-5-81

\begin{tabular}{cc}
$\begin{array}{c}\text { Depth } \\
(\mathbf{m})\end{array}$ & $\begin{array}{c}\text { T } \\
\text { (C) }\end{array}$ \\
\hline 0 & 12.35 \\
10 & 12.40 \\
15 & 13.39 \\
25 & 11.81 \\
30 & 11.90 \\
35 & 12.04 \\
40 & 12.17 \\
45 & 12.33 \\
50 & 12.64 \\
55 & 12.90 \\
60 & 12.92 \\
65 & 12.92 \\
70 & 12.94 \\
75 & 12.95 \\
80 & 12.94 \\
85 & 12.95 \\
90 & 12.96 \\
95 & 12.95 \\
100 & 12.95 \\
105 & 12.95 \\
110 & 12.95 \\
115 & 12.95 \\
120 & 12.95 \\
125 & 12.95 \\
130 & 12.95
\end{tabular}

Area: Iron County, Utah

B-16

Cadastral: T35S/R16W/S6 bbc

Site Name: Escalante Valley EVG-15

Latitude: $37^{\circ} 47^{\prime} 38^{\prime \prime} \mathrm{N}$.

Longitude: $113^{\circ} 41^{\prime} 29^{\prime \prime} \mathrm{W}$.

Elevation: $1572 \pm 0.7 \mathrm{~m}$

Depth to Water: $6 \mathrm{~m} \pm 2.5$

Depth Range (Grad. Calc.): 20 - 65m

Gradient: $0 \pm 1 \mathrm{C} / \mathrm{km}$

Drilling Completed by: 4-23-49

Thermal Logging Date: 11-3-81

\begin{tabular}{cc}
$\begin{array}{c}\text { Depth } \\
(\mathbf{m})\end{array}$ & $\begin{array}{c}\mathbf{T} \\
\text { (C) }\end{array}$ \\
\hline 0 & 15.61 \\
10 & 13.01 \\
15 & 13.01 \\
20 & 12.10 \\
25 & 12.09 \\
30 & 12.09 \\
35 & 12.10 \\
40 & 12.10 \\
45 & 12.11 \\
50 & 12.11 \\
55 & 12.11 \\
60 & 12.11 \\
65 & 12.11
\end{tabular}

Area: Iron County, Utah

B-17

Cadastral: T35S/R17W/S1 bcc

Site Name: Escalante Valley EVG-16

Latitude: $37^{\circ} 47^{\prime} 21^{\prime \prime} \mathrm{N}$.

Longitude: $113^{\circ} 42^{\prime} 39^{\prime \prime} \mathrm{W}$.

Elevation: $1574 \pm 0.7 \mathrm{~m}$

Depth to Water: $10 \mathrm{~m} \pm 2.5$

Depth Range (Grad. Calc.): 25 - 55m

Gradient: $0 \pm 1 \mathrm{C} / \mathrm{km}$

Drilling Completed by: 8-22-51

Thermal Logging Date: 11-2-81

\begin{tabular}{cc}
$\begin{array}{c}\text { Depth } \\
(\mathbf{m})\end{array}$ & $\begin{array}{c}\text { T } \\
\text { (C) }\end{array}$ \\
\hline 0 & 14.09 \\
10 & 12.70 \\
15 & 12.59 \\
20 & 12.08 \\
25 & 11.98 \\
30 & 11.98 \\
35 & 11.97 \\
40 & 11.97 \\
45 & 11.97 \\
50 & 11.97 \\
55 & 11.98 \\
59 & 12.00
\end{tabular}


Area: Iron County, Utah

Cadastral: T35S/R17W/S3 ccc

Site Name: Escalante Valley EVG-17

Latitude: $37^{\circ} 46^{\prime} 50^{\prime \prime} \mathrm{N}$.

Longitude: $113^{\circ} 44^{\prime} 48^{\prime \prime} \mathrm{W}$.

Elevation: $1581 \pm 0.7 \mathrm{~m}$

Depth to Water: $23 \mathrm{~m} \pm 2.5$

Depth Range (Grad. Calc.) : 30 - 55m

Gradient: $5 \pm 1 \mathrm{C} / \mathrm{km}$

Drilling Completed by: 3-12-47

Thermal Logging Date: 11-13-81

\begin{tabular}{cc}
$\begin{array}{c}\text { Depth } \\
\text { (m) }\end{array}$ & $\begin{array}{c}\text { T } \\
\text { (C) }\end{array}$ \\
\hline 0 & 11.39 \\
10 & 12.04 \\
15 & 12.24 \\
20 & 12.46 \\
25 & 12.73 \\
30 & 12.81 \\
35 & 12.85 \\
40 & 12.88 \\
45 & 12.90 \\
50 & 12.93 \\
55 & 12.95 \\
57 & 13.21
\end{tabular}

B-19

Area: Iron County, Utah

Cadastral: T35S/R17W/S1 ddc

Site Name: Escalante Valley EVG-18

Latitude: $37^{\circ} 46^{\prime} 24^{\prime \prime} \mathrm{N}$.

Longitude: $113^{\circ} 41^{\prime} 45^{\prime \prime} \mathrm{W}$.

Elevation: $1573 \pm 0.7 \mathrm{~m}$

Depth to Water: $18 \mathrm{~m} \pm 2.5$

Depth Range (Grad. Calc.): 25 - 45m

Gradient: $26 \pm 4 \mathrm{C} / \mathrm{km}$

Drilling Completed by : 4-24-65

Thermal Logging Date: 11-10-81

$\begin{array}{cc}\begin{array}{c}\text { Depth } \\ \text { (m) }\end{array} & \text { T } \\ \text { (C) }\end{array}$

B-18

Area: Iron County, Utah

Cadastral: T35S/R17W/S12 bcc

Site Name: Escalante Valley EVG-19

Latitude: $37^{\circ} 46^{\prime} 24^{\prime \prime} \mathrm{N}$.

Longitude: $113^{\circ} 42^{\prime} 36^{\prime \prime} \mathrm{W}$.

Elevation: $1576 \pm 0.7 \mathrm{~m}$

Depth to Water: $38 \mathrm{~m} \pm 2.5$

Depth Range (Grad. Calc.): 25 - 45m

Gradient: $2 \pm 1 \mathrm{C} / \mathrm{km}$

Drilling Completed by:

Thermal Logging Date: 11-2-81

\begin{tabular}{cc}
$\begin{array}{c}\text { Depth } \\
(\mathbf{m})\end{array}$ & $\begin{array}{c}\text { T } \\
(\mathbf{C})\end{array}$ \\
\hline 0 & - \\
10 & 10.28 \\
15 & 10.45 \\
20 & 10.44 \\
25 & 10.54 \\
30 & 10.54 \\
35 & 10.57 \\
40 & 10.58 \\
45 & 10.58 \\
50 & 10.58
\end{tabular}

Area: Iron County, Utah

Cadastral: T35S/R17W/S12 acc

Site Name: Escalante Valley EVG-20

Latitude: $37^{\circ} 46^{\prime} 23^{\prime \prime} \mathrm{N}$.

Longitude: $113^{\circ} 42^{\prime} 00^{\prime \prime} \mathrm{W}$.

Elevation: $1573 \pm 0.7 \mathrm{~m}$

Depth to Water: $20 \mathrm{~m} \pm 2.5$

Depth Range (Grad. Calc.): 25 - 40m

Gradient: $6 \pm 4 \mathrm{C} / \mathrm{km}$

Drilling Completed by: $5-4-60$

Thermal Logging Date: 11-11-81

\begin{tabular}{cc}
$\begin{array}{c}\text { Depth } \\
\text { (m) }\end{array}$ & $\begin{array}{c}\text { T } \\
\text { (C) }\end{array}$ \\
\hline 0 & 11.11 \\
10 & 10.62 \\
15 & 10.39 \\
20 & 10.58 \\
25 & 10.90 \\
30 & 10.91 \\
35 & 10.92 \\
40 & 10.99 \\
44 & 10.99
\end{tabular}


Area: Iron County, Utah

Cadastral: T35S/R17W/S18 abd

Site Name: Escalante Valley EVG-21

Latitude: $37^{\circ} 45^{\prime} 45^{\prime \prime} \mathrm{N}$.

Longitude: $113^{\circ} 47^{\prime} 24^{\prime \prime} \mathrm{W}$.

Elevation: $1595 \pm 0.7 \mathrm{~m}$

Depth to Water: $44 \mathrm{~m} \pm 2.5$

Depth Range (Grad. Calc.): 25 - 45m

Gradient: $35 \pm 3 \mathrm{C} / \mathrm{km}$

Drilling Completed by:

Thermal Logging Date: 11-10-81
Area: Iron County, Utah

Cadastral: T35S/R17W/S16 aca

Site Name: Escalante Valley EVG-22

Latitude: $37^{\circ} 45^{\prime} 41^{\prime \prime} \mathrm{N}$.

Longitude: $113^{\circ} 45^{\prime} 06^{\prime \prime} \mathrm{W}$.

Elevation: $1584 \pm 0.7 \mathrm{~m}$

Depth to Water: $26 \mathrm{~m} \pm 2.5$

Depth Range (Grad. Calc.): 15 - 30m

Gradient: $73 \pm 9 \mathrm{C} / \mathrm{km}$

Drilling Completed by: 11-7-80

Thermal Logging Date: 11-13-81

\begin{tabular}{ccccc}
$\begin{array}{c}\text { Depth } \\
(\mathbf{m})\end{array}$ & $\begin{array}{c}\text { T } \\
(\mathbf{C})\end{array}$ & & $\begin{array}{c}\text { Depth } \\
(\mathbf{m})\end{array}$ & $\begin{array}{c}\mathbf{T} \\
(\mathbf{C})\end{array}$ \\
\hline 0 & 19.61 & 0 & 13.98 \\
10 & 14.92 & 10 & 12.12 \\
15 & 14.46 & 15 & 12.45 \\
20 & 15.21 & 20 & 12.88 \\
25 & 14.17 & & 25 & 13.16 \\
30 & 14.36 & 30 & 13.57 \\
35 & 14.56 & 35 & 13.66 \\
40 & 14.70 & 40 & 13.76 \\
45 & 14.87 & 45 & 13.86 \\
50 & 14.92 & 50 & 13.96 \\
55 & 15.00 & 55 & 14.14
\end{tabular}

